SRNL-STI-2010-00353

Revision 0

Keywords: DWPF, TANK

FARM, LIQUID WASTE

OPERATIONS, SRAT, SME

Retention: Permanent

\title{
SLUDGE WASHING AND DEMONSTRATION OF THE DWPF FLOWSHEET IN THE SRNL SHIELDED CELLS FOR SLUDGE BATCH 6 QUALIFICATION
}

J. M. Pareizs

B. R. Pickenheim

C. J. Bannochie

A. L. Billings

N. E. Bibler

D. R. Click

October 2010

Savannah River National Laboratory

Savannah River Nuclear Solutions, LLC Aiken, SC 29808

Prepared for the U.S. Department of Energy under contract number DE-AC09-08SR22470.

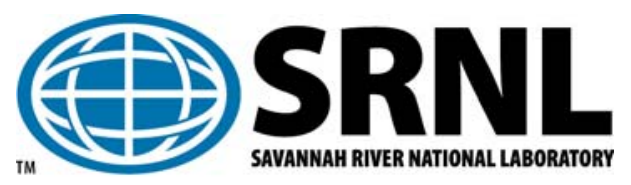


SRNL-STI-2010-00353

Revision 0

\section{DISCLAIMER}

This work was prepared under an agreement with and funded by the U.S. Government. Neither the U.S. Government or its employees, nor any of its contractors, subcontractors or their employees, makes any express or implied:

1. warranty or assumes any legal liability for the accuracy, completeness, or for the use or results of such use of any information, product, or process disclosed; or

2. representation that such use or results of such use would not infringe privately owned rights; or

3. endorsement or recommendation of any specifically identified commercial product, process, or service.

Any views and opinions of authors expressed in this work do not necessarily state or reflect those of the United States Government, or its contractors, or subcontractors.

\section{Printed in the United States of America}

Prepared for

U.S. Department of Energy 
SRNL-STI-2010-00353

Revision 0

\section{REVIEWS AND APPROVALS}

\section{AUTHORS:}

J. M. Pareizs, Process Technology Programs Date

B. R. Pickenheim, Process Technology Programs Date

C. J. Bannochie, Process Technology Programs

Date

A. L. Billings, Process Technology Programs

Date

N. E. Bibler, Process Technology Programs

Date

D. R. Click, Analytical Development

Date

TECHNICAL REVIEW:

D. C. Koopman, Process Technology Programs

Date

D. K. Peeler, Process Technology Programs

Date

APPROVAL:

C. C. Herman, Manager

Date

Process Technology Programs

S. L. Marra, Manager

Date

Environmental \& Chemical Process Technology Research Programs

J. E. Occhipinti, Manager

Date

Liquid Waste Engineering 
SRNL-STI-2010-00353

Revision 0

\section{ACKNOWLEDGEMENTS}

The authors would like to recognize the invaluable support of the Savannah River National Laboratory (SRNL) Shielded Cells technicians and management for the in-cells work; SRNL-Analytical Development researchers and technicians for all other analyses; T. B. Edwards of the SRNL Statistical Consultation group for statistical analysis support; and the SRNL Glass Shop for providing glassware and other miscellaneous hardware. 
SRNL-STI-2010-00353

Revision 0

\section{EXECUTIVE SUMMARY}

Prior to initiating a new sludge batch in the Defense Waste Processing Facility (DWPF), Savannah River National Laboratory (SRNL) is required to simulate this processing, including Chemical Process Cell (CPC) simulation, waste glass fabrication, and chemical durability testing. This report documents this simulation for the next sludge batch, Sludge Batch 6 (SB6). SB6 consists of Tank 12 material that has been transferred to Tank 51 and subjected to Low Temperature Aluminum Dissolution (LTAD), Tank 4 sludge, and $\mathrm{H}$-Canyon Pu solutions. Following LTAD and the Tank 4 addition, Liquid Waste Operations (LWO) provided SRNL a 3 L sample of Tank 51 sludge for SB6 qualification. Pu solution from $\mathrm{H}$ Canyon was also received. SB6 qualification included washing the sample per LWO plans/projections (including the addition of $\mathrm{Pu}$ from $\mathrm{H}$ Canyon), DWPF CPC simulations, waste glass fabrication (vitrification), and waste glass characterization and chemical durability evaluation.

The following are significant observations from this demonstration.

- Sludge settling improved slightly as the sludge was washed.

- SRNL recommended (and the Tank Farm implemented) one less wash based on evaluations of Tank 40 heel projections and projections of the glass composition following transfer of Tank 51 to Tank 40.

- Thorium was detected in significant quantities ( $>0.1 \mathrm{wt} \%$ of total solids) in the sludge. In past sludge batches, thorium has been determined by Inductively Coupled Plasma-Mass Spectroscopy (ICP-MS), seen in small quantities, and reported with the radionuclides. As a result of the high thorium, SRNL-AD has added thorium to their suite of Inductively Coupled Plasma-Atomic Emission Spectroscopy (ICP-AES) elements.

- The acid stoichiometry for the DWPF Sludge Receipt and Adjustment Tank (SRAT) processing of $115 \%$, or $1.3 \mathrm{~mol}$ acid per liter of SRAT receipt slurry, was adequate to accomplish some of the goals of SRAT processing: nitrite was destroyed to below $1,000 \mathrm{mg} / \mathrm{kg}$ and mercury was removed to below the DWPF target with $750 \mathrm{~g}$ of steam per g of mercury. However, rheological properties did not improve and were above the design basis.

- Hydrogen generation rates did not exceed DWPF limits during the SRAT and Slurry Mix Evaporator (SME) cycles. However, hydrogen generation during the SRAT cycle approached the DWPF limit.

- The glass fabricated with the Tank 51 SB6 SME product and Frit 418 was acceptable with respect to chemical durability as measured by the Product Consistency Test (PCT). The PCT response was also predictable by the current durability models of the DWPF Product Composition Control System (PCCS). It should be noted, however, that in the first attempt to make glass from the SME product, the contents of the fabrication crucible foamed over. This may be a result of the SME product's 
SRNL-STI-2010-00353

Revision 0

REDOX (Reduction/Oxidation $-\mathrm{Fe}^{2+} / \mathrm{Se}$ ) of 0.08 (calculated from SME product analytical results).

The following are recommendations drawn from this demonstration.

- In this demonstration, at the request of DWPF, SRNL caustic boiled the SRAT contents prior to acid addition to remove water (to increase solids concentration). During the nearly five hours of caustic boiling, $700 \mathrm{ppm}$ of antifoam was required to control foaming. SRNL recommends that DWPF not caustic boil/concentrate SRAT receipt prior to acid addition until further studies can be performed to provide a better foaming control strategy or a new antifoam is developed for caustic boiling.

- Based on this set of runs and a recently completed demonstration with the SB6 Waste Acceptance Product Specifications (WAPS) sample, it is recommended that DWPF not add formic acid at the design addition rate of two gallons per minute for this sludge batch. A longer acid addition time appears to be helpful in allowing slower reaction of formic acid with the sludge and possibly decreases the chance of a foam over during acid addition. 


\section{TABLE OF CONTENTS}

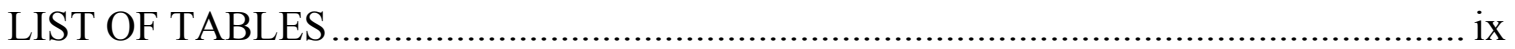

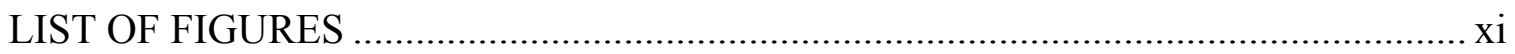

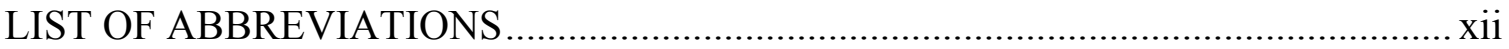

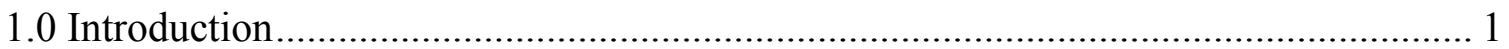

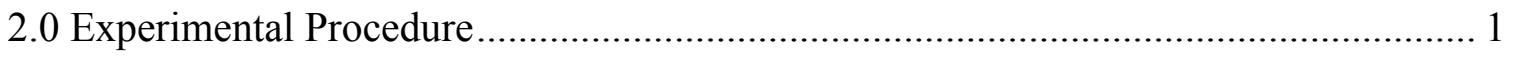

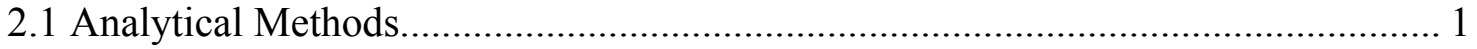

2.1.1 As-Received, SRAT Receipt and SRAT Product Characterization.................... 2

2.1.2 Glass Dissolution Methods and Analyses ...................................................... 2

2.1.3 Supernate Sample Preparation For Analysis .................................................. 3

2.1.4 Weight Percent Solids and Density Measurements.......................................... 3

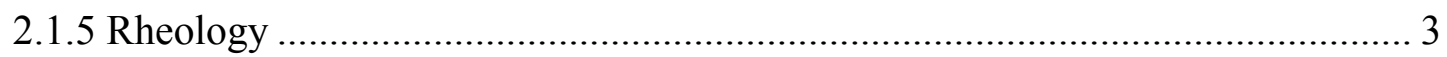

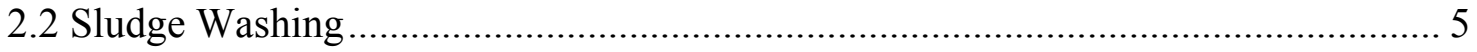

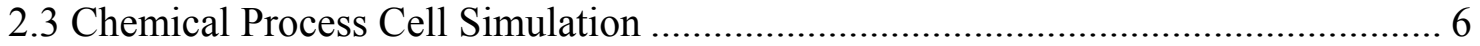

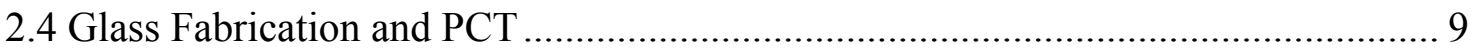

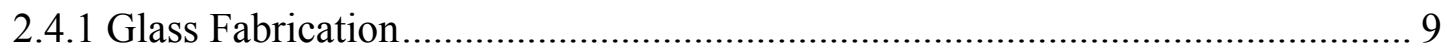

2.4.2 Glass Dissolution Methods and Analyses ......................................................... 9

2.4.3 Standard ASTM 1285 Leach Test Procedure.................................................. 10

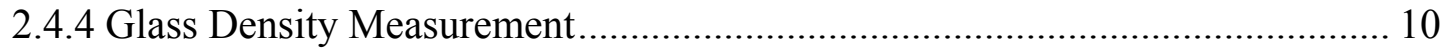

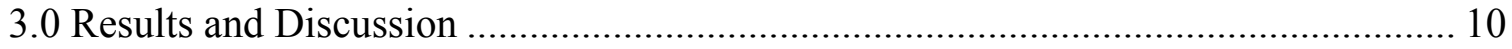

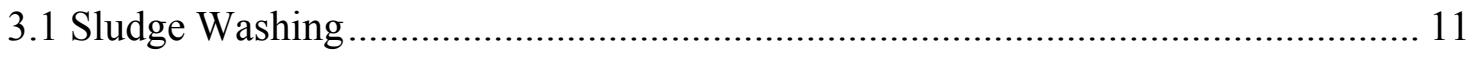

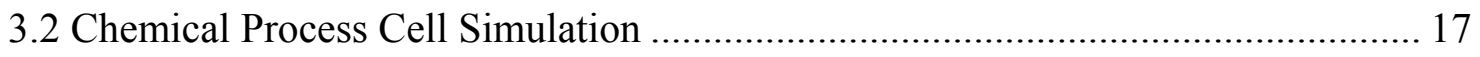

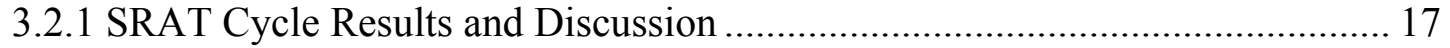

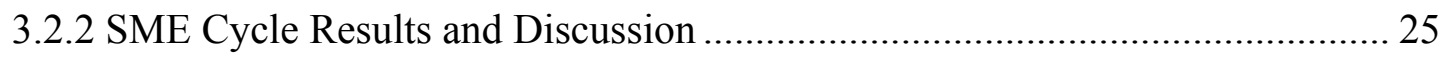

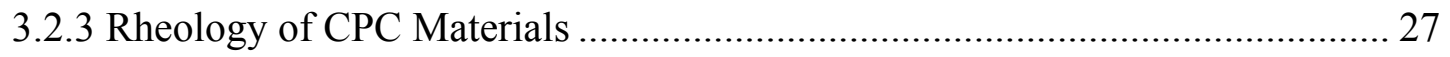

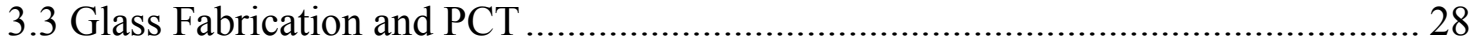

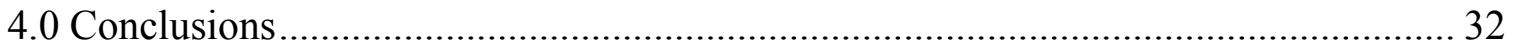

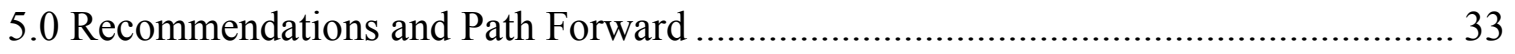

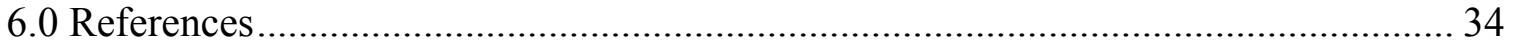

Appendix A. Excerpt From November 10, 2009 Tank Farm Washing Spreadsheet....... 36

Appendix B. SRNL Sludge Batch 6 Washing Mass Balance...................................... 41 
SRNL-STI-2010-00353

Revision 0

Appendix C. SRNL Sludge Batch 6 Analytical Results ............................................ 44

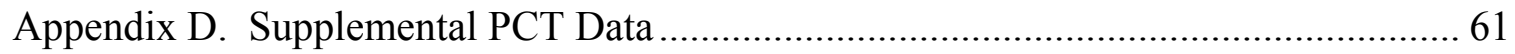

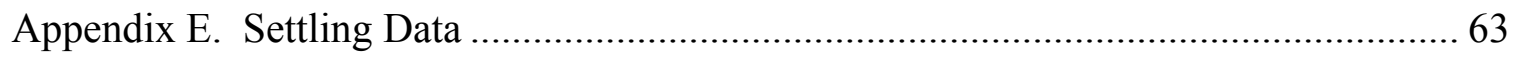

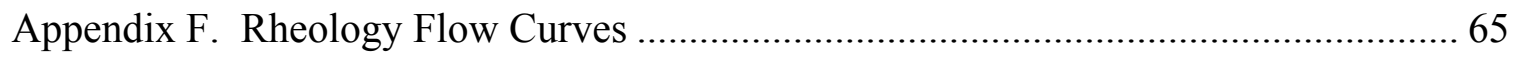


SRNL-STI-2010-00353

Revision 0

\section{LIST OF TABLES}

Table 2-1. MV I and MV II Rotor Specifications and Flow Curve Program ................... 5

Table 2-2. Summary of SB6 Qualification CPC Processing ......................................... 7

Table 3-1. Major Elements in the Tank 51 SB6 Qualification Sample ........................... 12

Table 3-2. Weight Percent Solids and Selected Supernate Constituents Measured During SB6 Washing 13

Table 3-3. SRAT Receipt Tank 51 SB6 Qualification Sample Noble Metals and Minor Elements

Table 3-4. SRAT Receipt Tank 51 SB6 Qualification Sample Anions and Carbon ....... 15

Table 3-5. SRAT Receipt Tank 51 SB6 Qualification Sample Total Base, Free Hydroxide, and Other Bases Excluding Carbonate............................................... 16

Table 3-6. Acid Calculation Inputs for the Tank 51 SB6 Qualification CPC Simulation 18

Table 3-7. SRAT Cycle Acid Requirements.

Table 3-8. Antifoam Additions During Caustic Boiling/Concentration........................ 19

Table 3-9. Antifoam Additions After Formic Acid Addition ....................................... 20

Table 3-10. Characterization Results of the SB6 Qualification SRAT Product ............... 21

Table 3-11. SB6 Qualification SRAT Cycle Maximum Observed Hydrogen, Carbon Dioxide, and Nitrous Oxide DWPF Scale Concentrations and Generation Rates ..... 22

Table 3-12. Physical Properties of As-Made SB6 SME Product (Prior to Dilution to 45 wt $\%$ Total Solids) ......................................................................................... 25

Table 3-13. SB6 SME Product (at 45 wt \% Total Solids) Density, Anion, and Cation Concentrations

Table 3-14. SB6 SME Cycle Maximum Observed Hydrogen, Carbon Dioxide, and Nitrous Oxide DWPF Scale Concentrations and Generation Rates.....

Table 3-15. SB6 SRAT Receipt Slurry Rheology Data Before and After Concentration plus SRAT Product Rheology Data

Table 3-16. Average of Elemental Concentrations Measured in SB6 Qualification Glass

Table 3-17. Measured SB6 Qualification Glass Composition on an Oxide Basis for Input

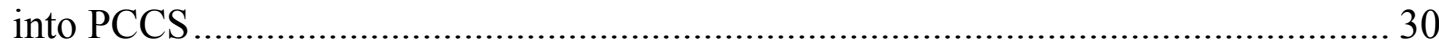

Table 3-18. PCCS Results for SB6 Qualification Glass ............................................ 31 
SRNL-STI-2010-00353

Revision 0

Table 3-19. PCT Results for ARM, EA and the SB6 Qualification Glass 31

Table C - 1. Density and Weight Percent Solids for Tank 51 SB6 Qualification Sample45

Table C - 2. Concentrations of Elements in Total Dried Solids and Calcined Solids for the As-Received Tank 51 SB6 Qualification Sample 46

Table C - 3. Concentrations of Noble Metals and Silver in Total Dried Solids for the AsReceived Tank 51 SB6 Qualification Sample.

Table C - 4. Concentrations of Soluble Elements in the As-Received SB6 Qualification Sample Supernate

Table C - 5. Concentrations of Anions on a Supernate Basis for the As-Received Tank 51 SB6 Qualification Sample.

Table C - 6. Supernate Concentrations of Total Base, Free Hydroxide, and Other Bases Excluding Carbonate for the As-Received Tank 51 SB6 Qualification Sample........ 48

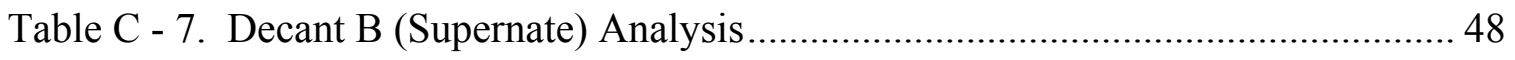

Table C - 8. Decant C (Supernate) Analysis............................................................... 49

Table C - 9. Post Decant C Slurry and Supernate Density and Weight Percent Solids... 49

Table C - 10. Post Decant C Aqua Regia Digestion of Total Solids ............................. 50

Table C - 11. Decant D (Supernate) Analysis....................................................... 50

Table C - 12. Decant E (Supernate) Analysis .............................................................. 51

Table C - 13. Decant F (Supernate) Analysis ..................................................... 52

Table C - 14. Post Decant F Slurry and Supernate Density and Weight Percent Solids . 52

Table C - 15. Post Decant F Aqua Regia Digestion of Total Solids.............................. 53

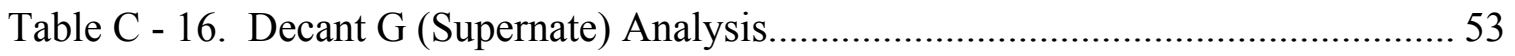

Table C - 17. Decant H (Supernate) Analysis............................................................ 54

Table C - 18. Decant I (Supernate) Analysis ........................................................... 55

Table C - 19. Densities and Weight Percent Solids for Tank 51 SB6 Qualification SRAT

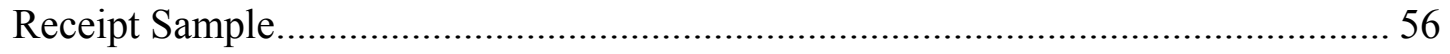

Table C - 20. Concentrations of Elements in Total Dried Solids and Calcined Solids for the Tank 51 SB6 Qualification SRAT Receipt Sample......................................... 57

Table C - 21. Concentrations of Noble Metals and Silver in Total Dried Solids for the SRAT Receipt Tank 51 SB6 Qualification Sample. ............................................ 58 
SRNL-STI-2010-00353

Revision 0

Table C - 22. Concentrations of Anions and Cations on a Slurry Basis for the SRAT

Receipt Tank 51 SB6 Qualification Sample ......................................................... 58

Table C - 23. Slurry Concentrations of Total Base, Free Hydroxide, and Other Bases

Excluding Carbonate for the SRAT Receipt Tank 51 SB6 Qualification Sample..... 58

Table C - 24. Slurry and Supernate Concentrations of TIC/TOC for the SRAT Receipt

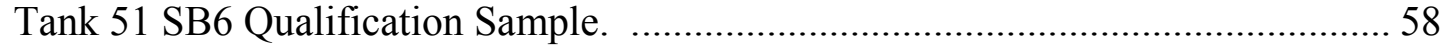

Table C - 25. Weight Percent Solids, Density, and pH of the SB6 Qualification SRAT

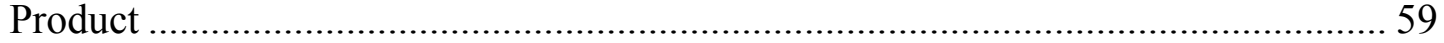

Table C - 26. Concentrations of Anions, Amonium, and Carbon on a Slurry Basis for the

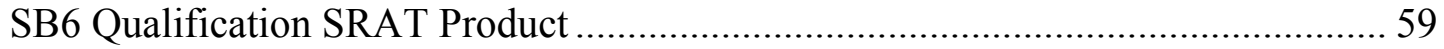

Table C - 27. Physical Properties of As-Made SB6 SME Product (Prior to Dilution to 45

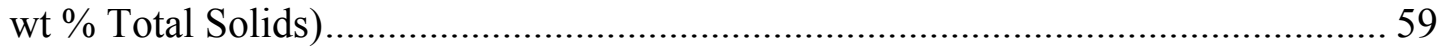

Table C - 28. SB6 SME Product (at 45 wt \% Total Solids) Density, Anion, and Cation

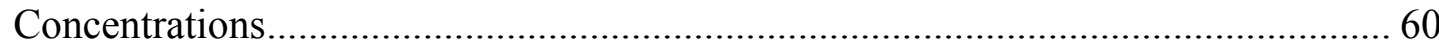

Table C - 29. SB6 SME Product (at 45 wt \% Total Solids) Carbon Analysis................. 60

Table D - 1. PCT Elemental Releases for ARM, EA and the SB6 Qualification Glass .. 62

\section{LIST OF FIGURES}

Figure 2-1. Photograph of Sludge Batch 6 Washing Vessel......................................... 5

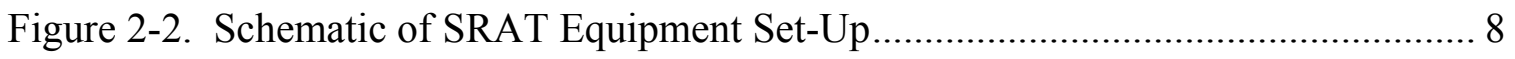

Figure 3-1. Graphical Presentation of Major Supernate Constituents ........................... 14

Figure 3-2. Graphical Presentation of Sulfur and Sulfate During Washing ................... 14

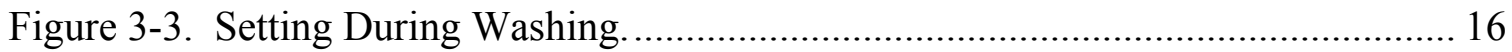

Figure 3-4. Plot of Gas Generation Rates (a) and Concentrations (b) During Caustic

Boiling/Concentration and During Acid Addition Prior to Foaming Event .............. 23

Figure 3-5. Plot of Gas Generation Rates (a) and Concentrations (b) Following Restart

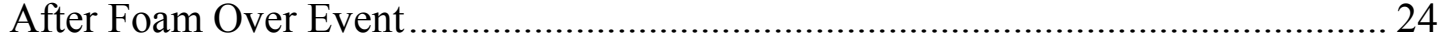

Figure 3-6. Offgas Data from the SB6 Qualification SME Cycle ............................... 27

Figure 3-7. Fit of $\log$ Normalized Release of B, Li, Na and Si (g/L) vs. del G $\mathrm{p}_{\mathrm{p}}$ for the measured releases of ARM, EA and the SB6 Qualification glasses. 


\section{LIST OF ABBREVIATIONS}

$\begin{array}{ll}\text { AD } & \text { Analytical Development } \\ \text { AR } & \text { Aqua Regia digestion } \\ \text { ARG-1 } & \text { Analytical Reference Glass }-1 \\ \text { ARM } & \text { Approved Reference Material } \\ \text { CPC } & \text { Chemical Process Cell } \\ \text { CVAA } & \text { Cold Vapor Atomic Absorption } \\ \text { C-XRD } & \text { Contained X-Ray Diffraction } \\ \text { DWPF } & \text { Defense Waste Processing Facility } \\ \text { EA } & \text { Environmental Assessment } \\ \text { FAVC } & \text { Formic Acid Vent Condenser } \\ \text { IC } & \text { Ion Chromatography } \\ \text { ICP-AES } & \text { Inductively Coupled Plasma-Atomic Emission Spectroscopy } \\ \text { ICP-MS } & \text { Inductively Coupled Plasma-Mass Spectroscopy } \\ \text { LRM } & \text { Low Activity Test Reference Material } \\ \text { LTAD } & \text { Low Temperature Aluminum Dissolution } \\ \text { LWO } & \text { Liquid Waste Operations } \\ \text { MA } & \text { Mixed Acid } \\ \text { MAR } & \text { Measurement Acceptability Region } \\ \text { MWWT } & \text { Mercury Water Wash Tank } \\ \text { NIST } & \text { National Institute of Standards and Testing } \\ \text { PCCS } & \text { Product Composition Control System } \\ \text { PCT } & \text { Product Consistency Test } \\ \text { PF } & \text { Peroxide Fusion digestion } \\ \text { R\&D } & \text { Research and Development } \\ \text { REDOX } & \text { Reduction/Oxidation (Fe }{ }^{2+} / \text { Fe) } \\ \text { SB6 } & \text { Sludge Batch 6 } \\ \text { SME } & \text { Slurry Mix Evaporator } \\ \text { SMECT } & \text { Slurry Mix Evaporator Condensate Tank } \\ \text { SRAT } & \text { Sludge Receipt and Adjustment Tank } \\ \text { SRNL } & \text { Savannah River National Laboratory } \\ \text { SRS } & \text { Savannah River Site } \\ \text { TIC } & \text { Total Inorganic Carbon } \\ \text { TTQAP } & \text { Task Technical and Quality Assurance Plan } \\ \text { WAPS } & \text { Waste Acceptance Product Specification } \\ & \end{array}$


SRNL-STI-2010-00353

Revision 0

\subsection{Introduction}

Sludge Batch 6 (SB6) consists of Tank 12 material that has been transferred to Tank 51 and subjected to Low Temperature Aluminum Dissolution (LTAD), Tank 4 sludge, and $\mathrm{H}-\mathrm{Canyon} \mathrm{Pu}$ solutions. Following LTAD and the Tank 4 addition, Liquid Waste Operations (LWO) provided the Savannah River National Laboratory (SRNL) a 3 L sample of Tank 51 sludge for SB6 qualification. ${ }^{1}$ Pu solution from H Canyon was also received. SB6 qualification included washing the sample per LWO plans/projections (including the addition of $\mathrm{Pu}$ from $\mathrm{H}$ Canyon), DWPF Chemical Process Cell (CPC) simulations, waste glass fabrication (vitrification), and waste glass characterization and chemical durability evaluation.

This report documents:

- The washing (addition of water to dilute the sludge supernate) and concentration (decanting of supernate) of the SB6 - Tank 51 qualification sample to adjust sodium content and weight percent insoluble solids to Tank Farm projections.

- The performance of a DWPF CPC simulation using the washed Tank 51 sample. The simulations included a Sludge Receipt and Adjustment Tank (SRAT) cycle, where acid was added to the sludge to destroy nitrite and reduce mercury, and a Slurry Mix Evaporator (SME) cycle, where glass frit was added to the sludge in preparation for vitrification. The SME cycle also included replication of five canister decontamination additions and concentrations. Processing parameters were based on work with a non radioactive simulant. ${ }^{2}$

- Vitrification of a portion of the SME product and characterization and durability testing (as measured by the Product Consistency Test (PCT)) of the resulting glass.

- Rheology measurements of the initial slurry samples and samples after each phase of CPC processing.

This work was controlled by a Task Technical and Quality Assurance Plan (TTQAP) ${ }^{3}$, and analyses were guided by an Analytical Study Plan ${ }^{4}$. This work is Technical Baseline Research and Development (R\&D) for the DWPF.

\subsection{Experimental Procedure}

The Experimental Procedure section is divided into several subsections that reflect the major parts of this task: sludge washing, CPC simulations, and glass fabrication and durability testing. An additional subsection, presented first, describes the analytical methods utilized for each of these tasks.

\subsection{Analytical Methods}

Described below are the methods and techniques used to generate the analytical data presented in this report. 
SRNL-STI-2010-00353

Revision 0

\subsubsection{As-Received, SRAT Receipt and SRAT Product Characterization}

Eight separate aliquots of the slurry for each type of sample were digested, four with $\mathrm{HNO}_{3} / \mathrm{HCl}$ (aqua regia ${ }^{5}$ ) in sealed Teflon ${ }^{\circledR}$ vessels and four in $\mathrm{Na}_{2} \mathrm{O}_{2}$ (alkali or peroxide fusion $^{6}$ ) using $\mathrm{Zr}$ crucibles. Due to the use of $\mathrm{Zr}$ crucibles and $\mathrm{Na}$ in the peroxide fusions, $\mathrm{Na}$ and $\mathrm{Zr}$ cannot be determined from this preparation. Additionally, other alkali metals, such as $\mathrm{Li}$ and $\mathrm{K}$, and alkaline earth metals, such as $\mathrm{Ca}$, that may be contaminants in the $\mathrm{Na}_{2} \mathrm{O}_{2}$ are not determined from this preparation. Three Analytical Reference Glass $-1^{7}$ (ARG-1) standards were digested along with a blank for each preparation. The ARG-1 glass allows for an assessment of the completeness of each digestion. Each aqua regia digestion and blank was diluted to $100 \mathrm{~mL}$ or $250 \mathrm{~mL}$ with de-ionized water and submitted to Analytical Development (AD) for inductively coupled plasma - atomic emission spectroscopy (ICP-AES) analysis, inductively coupled plasma - mass spectrometry (ICP-MS) analysis of masses 81-209 and 230-252, and cold vapor atomic absorption (CVAA) analysis for $\mathrm{Hg}$. Equivalent dilutions of the peroxide fusion digestions and blank were submitted to AD for ICP-AES analysis.

The aqua regia SRAT Receipt and SRAT Product solutions from digestion contained undissolved solids. A portion of the solids were recovered by filtration from one of the SRAT Receipt samples, submitted to Contained X-Ray Diffraction (C-XRD) for analysis and identified as boehmite. The undissolved solids in the SRAT Product digestion solutions were not analyzed but assumed to be boehmite as well.

The elemental concentrations reported are either a combination of both digestion methods and an average of eight data points or an average of four data points from one digestion method. The aqua regia and peroxide fusion methods agreed well for most major elements (greater than $0.5 \mathrm{wt} \%$ of total solids), except Al. See Click et al., SRNL-STI2010-00259, Revision 0, for a statistical comparison of digestion data.

\subsubsection{Glass Dissolution Methods and Analyses}

To support compositional analysis, a portion of the SB6 Qualification Glass had to be dissolved. In order to enhance dissolution, approximately $4 \mathrm{~g}$ of the glass was crushed and ground using agate cups, balls and caps in a mechanical pulverizing mixer mill. The glass was sieved and only the portion that passed through a 200 mesh $(<75 \mu \mathrm{m})$ brass sieve was used for the dissolutions. Weighed amounts (nominally $0.25 \mathrm{~g}$ ) of the crushed glass were then dissolved remotely by two different methods to ensure that all the elements of interest were dissolved and could be analyzed. The two methods were a sodium peroxide fusion at $675^{\circ} \mathrm{C}$ followed by a $\mathrm{HNO}_{3}$ uptake, and an acid dissolution in sealed vessels at $115^{\circ} \mathrm{C}$ using a combination of $\mathrm{HF}, \mathrm{HCl}$, and $\mathrm{HNO}_{3}$ acids. Boric acid was added to this latter dissolution method to complex excess fluoride. The solutions of the dissolved glass were diluted to known volumes so that approximately $15 \mathrm{~mL}$ aliquots could be safely removed from the Shielded Cells without exposing personnel to excess radiation. Four aliquots of the crushed SB6 Qualification Glass were dissolved by each technique. The aliquots were then submitted to AD, where they were analyzed by ICPAES, radioactive counting techniques, and by Inductively Coupled Plasma - Mass Spectroscopy (ICP-MS). Concurrent with each set of dissolutions in the Shielded Cells, three samples of ARG-1 were also dissolved to determine if the dissolutions were 
complete and the resulting analyses accurate. With each set of samples sent to AD, two samples of a multi-element standard containing known concentrations of $\mathrm{Al}, \mathrm{B}, \mathrm{Fe}, \mathrm{Li}$, $\mathrm{Na}$, and $\mathrm{Si}$ were also submitted.

\subsubsection{Supernate Sample Preparation For Analysis}

A portion of the well-mixed sludge slurry was filtered through a $0.45 \mu \mathrm{m}$ porosity filter. Portions of the filtered supernate were diluted with de-ionized distilled water or nitric acid to reduce the sample activity and allow removal from the Shielded Cells for chemical analysis. All sample preparations of the filtered supernate samples were conducted in quadruplicate. A blank was prepared along with the sample dilutions.

\subsubsection{Weight Percent Solids and Density Measurements}

The densities of the filtered supernate and the well-mixed slurry sample were measured in the Shielded Cells using calibrated plastic tubes with a nominal volume of $\sim 8.25 \mathrm{~mL}$. The density measurements were conducted in quadruplicate on each phase of the sample. The weight percent total solids in the slurry sample were measured in the Shielded Cells using a conventional drying oven at $110^{\circ} \mathrm{C}$. The sample was dried until repeated weights indicated no further loss of water. The weight percent dissolved solids in a sample of the filtered supernate were measured in the same manner. All weight percent solids measurements were made in quadruplicate. The weight percent insoluble solids and weight percent soluble solids in the slurry sample were calculated using the equations shown below.

Equation 1

$$
W_{i s} \frac{W_{t s}-W_{d s}}{1-W_{d s}}
$$

Equation 2

$$
W_{s s}=W_{t s}-W_{i s}
$$

where:

$\mathrm{W}_{\text {is }}=$ weight fraction of insoluble solids in the slurry

$\mathrm{W}_{\mathrm{ss}}=$ weight fraction of soluble solids in the slurry

$\mathrm{W}_{\mathrm{ts}}=$ weight fraction of total solids in the slurry

$\mathrm{W}_{\mathrm{ds}}=$ weight fraction of dissolved solids in the filtered supernate

Thus:

$\mathrm{Wt} \%$ dissolved solids $=(\mathrm{wt}$ dissolved solids/wt of supernate $) \times 100$

$\mathrm{Wt} \%$ total solids $=(\mathrm{wt}$ total solids/wt of total slurry $) \times 100$

$\mathrm{Wt} \%$ insoluble solids $=(\mathrm{wt}$ insoluble solids/wt of total slurry $) \times 100$

$\mathrm{Wt} \%$ soluble solids $=($ wt of dissolved solids/wt of total slurry $) \times 100$

\subsubsection{Rheology}

Rheological properties of radioactive samples are determined using a Haake M5/RV30 rotoviscometer. The M5/RV30 is a Searle sensor system, where the bob rotates and the cup is fixed. The torque and rotational speed of the bob are measured. Heating/cooling of the cup/sample/bob is through the holder that holds the cup. The shear stress is 
determined from the torque measurement and is independent of the rheological properties. Conditions that impact the measured torque are; slip (material does not properly adhere to the rotor or cup), phase separation (buildup of liquid layer on rotor), sedimentation (particles settling out of the shearing zone), homogeneous sample (void of air), lack of sample (gap not filled), excess sample (primarily impacts rheologically thin fluids), completely filling up the void below the bob (air buffer that is now filled with fluid) and Taylor vortices. The first five items yield lower stresses and the last three add additional stresses. The shear rate is geometrically determined using the equations of change (continuity and motion) and is that for a Newtonian fluid. This assumption also assumes that the flow field is fully developed and the flow is laminar. The shear rate can be calculated for non-Newtonian fluid using the measured data and fitting this data to the rheological model or corrected as recommended by Darby ${ }^{8}$. In either case, for shear thinning non-Newtonian fluids typical of Savannah River Site (SRS) sludge wastes, the corrected shear rates are greater than their corresponding Newtonian shear rates, resulting in a thinner fluid. Correcting the flow curves will not be performed in this task, resulting in a slightly more viscous fluid.

The bob typically used for measuring tank sludge or SRAT product is the MV I rotor. For SME product, the MV II rotor is used to perform the measurements, due to the larger frit particles that are present in the SME product. The MV II has a larger gap to accommodate the larger frit particles. The shape, dimensions, and geometric constants for the MV I and MV II rotors are provided in Table 2-1.

Prior to performing the measurements, the rotors and cups are inspected for physical damage. The torque/speed sensors and temperature bath are verified for functional operability using a bob/cup combination with a National Institute of Standards and Technology (NIST) traceable Newtonian oil standard, using the MV I rotor. The resulting flow curves are then fitted as a Newtonian fluid and this calculated viscosity must be within $\pm 10 \%$ of the reported NIST viscosity at a given temperature for the system to be considered functionally operable. A N10 oil standard was used to verify system operability prior to the sludge measurements.

The flow curves for the sludge are fitted to the down curves using the Bingham Plastic rheological model, Equation 3, where $\tau$ is the measured stress $(\mathrm{Pa}), \tau_{\mathrm{o}}$ is the Bingham Plastic yield stress $(\mathrm{Pa}), \mu_{\infty}$ is the plastic viscosity $(\mathrm{Pa} \cdot \mathrm{sec})$, and $\dot{\gamma}$ is the measured shear rate $\left(\mathrm{sec}^{-1}\right)$. During all these measurements, the sample remained in the cup for the $2^{\text {nd }}$ measurement, due to the sample availability.

Equation 3

$$
\tau=\tau_{o}+\mu_{\infty} \dot{\gamma}
$$


Table 2-1. MV I and MV II Rotor Specifications and Flow Curve Program

\begin{tabular}{|c|c|c|c|}
\hline Rotor Design & \multicolumn{3}{|c|}{ Dimensions and Flow Curve Program } \\
\hline & Rotor Type & MV I & MV II \\
\hline & Rotor radius $-\mathrm{R}_{\mathrm{i}}(\mathrm{mm})$ & 20.04 & 18.40 \\
\hline & Cup Radius - $\mathrm{R}_{\mathrm{a}}(\mathrm{mm})$ & 21.0 & 21.0 \\
\hline & Height of rotor $-\mathrm{L}(\mathrm{mm})$ & 60 & 60 \\
\hline & $\begin{array}{c}\text { Sample Volume }\left(\mathrm{cm}^{3}\right) \\
\text { minimum }\end{array}$ & 40 & 55 \\
\hline & A factor $(\mathrm{Pa} / \%$ torque $)$ & 3.22 & 3.76 \\
\hline & $\mathrm{M}$ factor $\left(\mathrm{s}^{-1} / \% \mathrm{RPM}\right)$ & 11.7 & 4.51 \\
\hline & Shear rate range $\left(\mathrm{s}^{-1}\right)$ & $0-600$ & $0-300$ \\
\hline & Ramp up time (min) & 5 & 5 \\
\hline & Hold time (min) & 1 & 1 \\
\hline & Ramp down time (min) & 5 & 5 \\
\hline
\end{tabular}

\subsection{Sludge Washing}

The as-received sludge was placed into a 4-L glass vessel. The vessel was fitted with an agitator shaft to facilitate mixing. The vessel had volume graduations to aid in settling observations and decant/addition volumes. A photograph of the washing vessel is shown in Figure 2-1. Prior to washing, a subsample was taken for characterization.

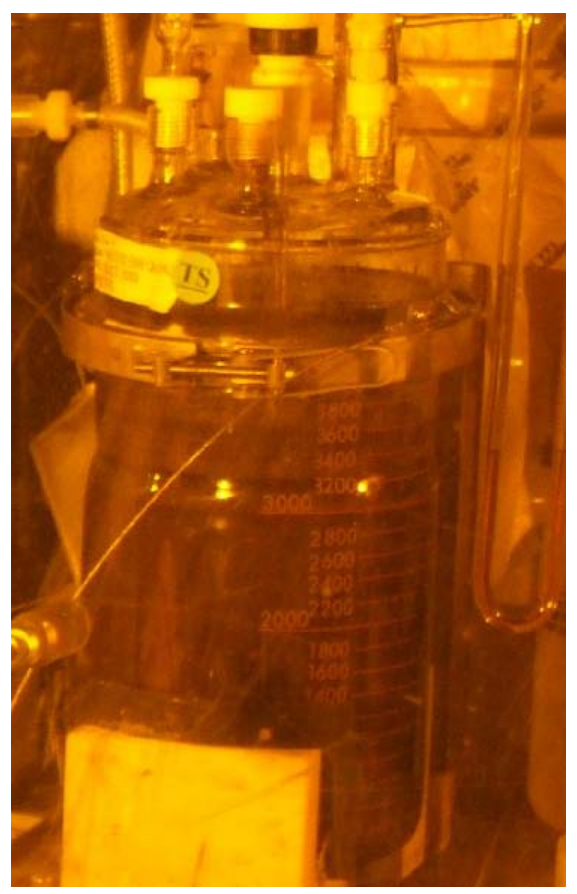

Figure 2-1. Photograph of Sludge Batch 6 Washing Vessel

In past sludge batches, a high density polyethylene bottle was used, and the entire vessel would be weighed before and after additions and decants. A glass vessel was utilized in this sludge batch to better evaluate sludge settling. Therefore, because of size and risk of breakage, washing was predominantly done by volume. However, masses of additions and decants were recorded. 
Washing (addition and decant amounts) followed Tank Farm plans of November 10, 2009. . An excerpt of this spreadsheet is given in Appendix A. SRNL washing and decant amounts were determined by simple ratios:

SRNL Addition (decant) Volume $=$ Tank Farm Addition (Decant) Volume $\times \frac{\text { SRNL Sludge/Slurry Volume }}{\text { Tank Farm Sludge/Slurry Volume }}$

SRNL washing, decant amounts, and sample amounts are given in Appendix B.

Supernate was characterized (elementals and anions) following each decant. Slurry samples were taken after Decants $\mathrm{C}$ and $\mathrm{F}$ for a more thorough characterization (aqua regia digestions, weight $\%$ total solids). Following the addition of Wash I, a supernate sample was taken. Based on elemental and anion results (primarily sodium), SRNL recommended that washing be stopped, and LWO concurred. SRNL decanted as much supernate as possible (Decant I) to maximize the amount of insoluble solids to be sent to DWPF. Rheological properties of the resultant sludge were measured to ensure the sludge met the design basis limits (supernate would have been added back to lower yield stress and consistency if necessary). The slurry following Decant I became the SB6 Qualification SRAT receipt material.

Sludge level was periodically recorded during settling after wash water additions to provide a semi-qualitative assessment of settling behavior throughout washing.

\subsection{Chemical Process Cell Simulation}

This section describe the DWPF CPC simulations using the SRNL-washed Tank 51 Sludge Batch 6 sample. The simulations were performed in the SRNL Shielded Cells.

DWPF simulations (SRAT and SME cycles) using the SRNL washed Tank 51 SB6 qualification sample were conducted following procedures in the Environmental and Chemical Process Technology Research Programs Section procedure manual. ${ }^{10}$ A summary of each cycle is presented in Table 2-2. At the request of the DWPF, the receipt sample was concentrated from $9.9 \mathrm{wt} \%$ insoluble solids to approximately 12 wt $\%$ total solids by boiling prior to acid addition. 
SRNL-STI-2010-00353

Revision 0

Table 2-2. Summary of SB6 Qualification CPC Processing

\begin{tabular}{|c|c|}
\hline SRAT Cycle & SME Cycle \\
\hline $\begin{array}{l}\text { - } \text { Acid Calculation } \\
\text { - } \text { Concentration (boiling) to raise } \\
\text { insoluble solids to } 12 \mathrm{wt} \% \\
\text { - } \\
\text { Cooling to approximately } 80{ }^{\circ} \mathrm{C} \\
\text { for sampling } \\
\text { - } \text { Heating to } 93{ }^{\circ} \mathrm{C} \\
\text { - } \text { Addition of nitric and formic acids } \\
\text { per acid calculation } \\
\text { - } \quad \text { Heat to boiling } \\
\text { - } \text { Concentration (water removal) to a } \\
\text { target wt } \% \text { total solids } \\
\text { - } \text { Reflux to obtain a total time at } \\
\text { boiling of } 35 \text { hours at a DWPF } \\
\text { boil-up rate of } 5,000 \mathrm{lb} \text { steam } / \mathrm{h} \\
\end{array}$ & $\begin{array}{l}\text { - Addition and removal of water to } \\
\text { simulate addition and removal of } \\
\text { water from the decontamination of } \\
5 \text { glass canisters } \\
\text { - Addition of frit and dilute formic } \\
\text { acid in two batches to target } 34 \% \\
\text { waste loading } \\
\text { Concentration (water removal) to } \\
\text { target } 45-50 \mathrm{wt} \% \text { total solids. }\end{array}$ \\
\hline
\end{tabular}

The SB6 qualification CPC processing was performed using a vessel designed to process one liter of sludge. The SRAT rig was assembled and tested in the SRNL Shielded Cells Mockup area and placed into the Shielded Cells fully assembled. A detailed description of the SRAT rig and testing of the rigs can be found in reference number 11. Two rigs were ultimately needed after a significant foam-over of sludge in the first rig. The intent of the equipment is to functionally replicate the DWPF processing vessels. The glass kettle is used to replicate both the SRAT and the SME, and it is connected to the SRAT Condenser and the Mercury Water Wash Tank (MWWT). Because the DWPF Formic Acid Vent Condenser (FAVC) does not directly impact SRAT and SME chemistry, it is not included in SRNL Shielded Cells CPC processing. Instead, a simple "cold finger" condenser is used to cool offgas to approximately $20{ }^{\circ} \mathrm{C}$ below ambient to remove excess water before the gas reaches the gas chromatograph for characterization. The Slurry Mix Evaporator Condensate Tank (SMECT) is represented by a sampling bottle that is used to remove condensate through the MWWT. For the purposes of this paper, the condensers and wash tank are referred to as the offgas components. A sketch of the experimental setup is given as Figure 2-2. 
SRNL-STI-2010-00353

Revision 0

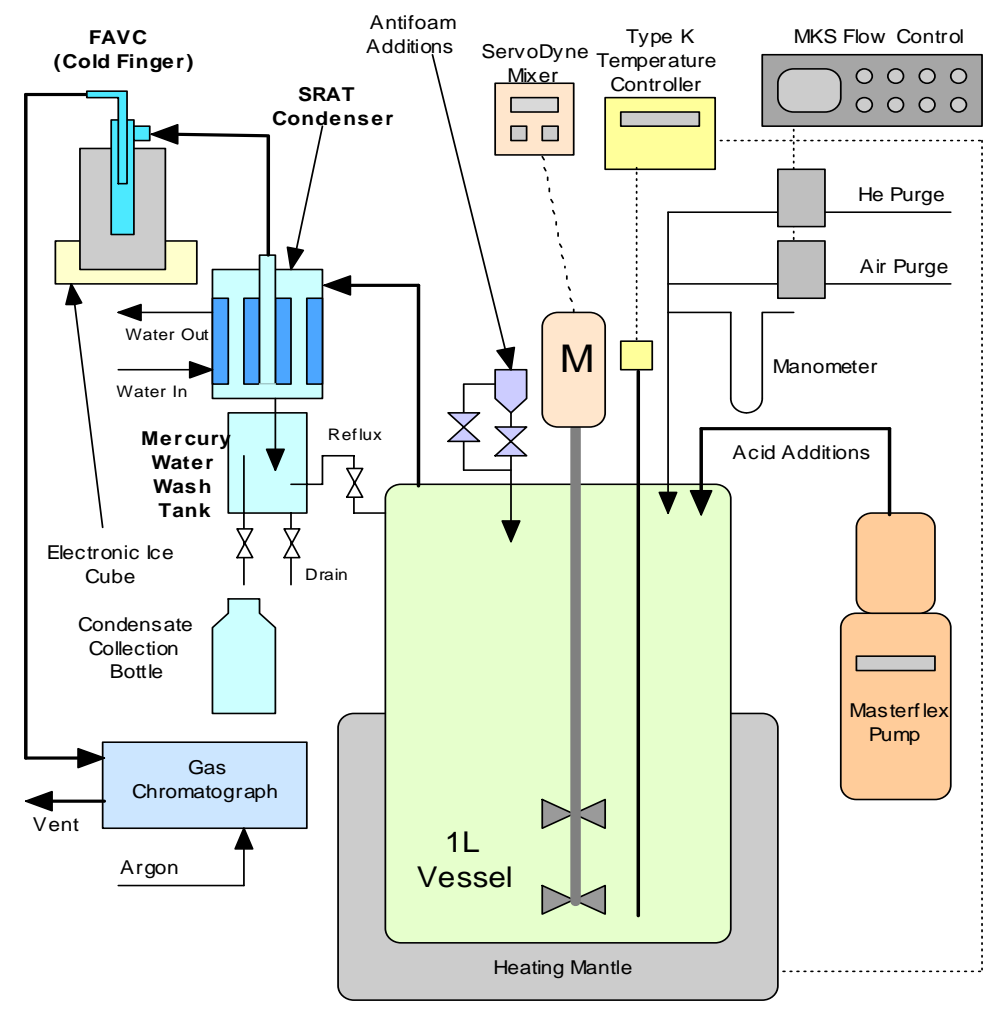

Figure 2-2. Schematic of SRAT Equipment Set-Up

Helium was introduced at a concentration of $0.5 \%$ of the total air purge as an inert tracer gas so that total amounts of generated gas and peak generation rates could be calculated. Off-gas concentrations of hydrogen, oxygen, nitrogen, nitrous oxide, and carbon dioxide concentrations were measured during the experiments using in-line instrumentation (an Agilent 3000 series micro GC). Helium was introduced at a concentration of $0.5 \%$ of the total air purge as an inert tracer gas so that total amounts of generated gas and peak generation rates could be calculated. During the runs, the kettle was visually monitored to observe reactions that were occurring to include foaming, air entrainment, rheology changes, loss of heat transfer capabilities, and offgas carryover. Observations were recorded in laboratory notebooks ${ }^{12,13}$ and are discussed in Sections 3.2.1 (SRAT cycle) and 3.2.2 (SME cycle).

Concentrated nitric acid (50-wt\%) and formic acid (90-wt $\%)$ were used to acidify the sludge and perform neutralization and reduction reactions during processing. The amounts of acid to add were determined using the existing DWPF acid addition equation in the 6/1/07 version of the SRNL acid calculation spreadsheet ${ }^{14}$. The split of the acid was determined using the latest Reduction/Oxidation (REDOX) equation. ${ }^{15}$ To account for the reactions and anion destructions that occur during processing, assumptions about nitrite destruction, nitrite-to-nitrate conversion, and formate destruction were made based on results from SB6 simulant $\mathrm{CPC}$ testing. Acid stoichiometry and reflux time were also based on CPC processing of SB6 simulant sludge slurry. ${ }^{2}$ 
SRNL-STI-2010-00353

Revision 0

\subsection{Glass Fabrication and PCT}

\subsubsection{Glass Fabrication}

There were two attempts at glass fabrication. In the first attempt, approximately $100 \mathrm{~g}$ of SME product (SRAT product with Frit 418 ) was placed in a $95 \%$ platinum $/ 5 \%$ gold crucible and dried overnight at $110{ }^{\circ} \mathrm{C}$. After drying, the material was then placed in a room temperature furnace which heated at $5{ }^{\circ} \mathrm{C}$ per min to a melting temperature of $1150{ }^{\circ} \mathrm{C}$. The sample was held at $1150^{\circ} \mathrm{C}$ for four hours. Unfortunately, the contents of the crucible foamed over during this melting process. The REDOX $\left(\mathrm{Fe}^{2+} / \Sigma \mathrm{Fe}\right)$ was calculated to be 0.08 based on the current REDOX equation using the SME product analytical results and the $\mathrm{Mn}$ from the glass analysis. ${ }^{15}$

In the second attempt, dried SME product was divided into four nearly equal portions. The first portion was heated to $1150{ }^{\circ} \mathrm{C}$ and held approximately fifteen minutes. The remaining portions were then added incrementally, allowing the crucible to return to temperature between each addition, resulting in a total time at $1150{ }^{\circ} \mathrm{C}$ of four hours. The sample was then quickly quenched to ambient temperature by placing the crucible in a shallow pan of water. No water contacted the glass during cooling. This glass was fabricated without incident. It appeared black and shiny, with no visible salt layer, crystals, or other inhomogeneities. This glass is referred to as the SB6 Qualification Glass and was used for the glass chemical and PCT analyses.

\subsubsection{Glass Dissolution Methods and Analyses}

To support compositional analysis, a portion of the SB6 Qualification Glass had to be dissolved. In order to enhance dissolution, approximately $4 \mathrm{~g}$ of the glass was crushed and ground using agate cups, balls and caps in a mechanical pulverizing mixer mill. The glass was sieved and only the portion that passed through a 200 mesh $(<75 \mu \mathrm{m})$ brass sieve was used for the dissolutions. Weighed amounts (nominally $0.25 \mathrm{~g}$ ) of the crushed glass were then dissolved remotely by two different methods to ensure that all the elements of interest were dissolved and could be analyzed. The two methods were a sodium peroxide fusion (PF) at $675^{\circ} \mathrm{C}$ followed by a $\mathrm{HNO}_{3}$ uptake, and a mixed acid dissolution (MA) in sealed vessels at $115^{\circ} \mathrm{C}$ using a combination of $\mathrm{HF}, \mathrm{HCl}$, and $\mathrm{HNO}_{3}$ acids. Boric acid was added to this latter dissolution method to complex excess fluoride. The solutions of the dissolved glass were diluted to known volumes so that approximately $15 \mathrm{~mL}$ aliquots could be safely removed from the Shielded Cells without exposing personnel to excess radiation.

The aliquots were then submitted to AD where they were analyzed by ICP-AES. Aliquots of the peroxide fusion dissolutions were also submitted for ICP-MS analysis and radioactive counting techniques. Concurrent with each set of dissolutions in the Shielded Cells, three samples of the ARG-1 and the Low Activity Test Reference Material (LRM) were also dissolved to determine if the dissolutions were complete and the resulting analyses accurate. With each set of samples sent to AD, two samples of a multi-element standard containing known concentrations of $\mathrm{Al}, \mathrm{B}, \mathrm{Fe}, \mathrm{Li}, \mathrm{Na}$, and $\mathrm{Si}$ were also submitted. 
SRNL-STI-2010-00353

Revision 0

\subsubsection{Standard ASTM 1285 Leach Test Procedure}

The durability of the SB6 Qualification Glass was measured using the ASTM 1285 standard nuclear waste glass leach test using the procedure prescribed in Test Method A. ${ }^{16}$ This test is commonly referred to as the PCT. The purpose of the PCT is to confirm that the SB6 Qualification Glass has a durability that meets the criterion specified by the WAPS for repository acceptance. ${ }^{17}$ WAPS 1.3 specifies that the mean concentrations of $\mathrm{B}, \mathrm{Li}$, and $\mathrm{Na}$ in the leachate, after normalizing for the concentrations in the glass, shall each be less than those of the Environmental Assessment (EA) glass. ${ }^{18}$ These normalized concentrations represent the concentration of leached glass in PCT assuming all elements in the glass are soluble. DWPF complies with this criterion by demonstrating that the mean PCT results are at least two standard deviations below the mean PCT results of the EA glass.

The ASTM 1285 Test Method A is a crushed glass (-100 to +200 mesh or 75 to $149 \mu \mathrm{m})$ leach test at $90{ }^{\circ} \mathrm{C}$ for 7 days using DI water in sealed stainless steel vessels. The test was performed in quadruplicate for the SB6 Qualification Glass. Duplicate blanks and triplicate samples of the standard glass [Accepted Reference Material (ARM)] and triplicate samples of the EA glass were also tested with the samples. In the PCT, $10 \mathrm{~mL}$ of DI water are used for each gram of glass. Nominally $1.7 \mathrm{~g}$ of glass and $17 \mathrm{~mL}$ of DI water were used in stainless steel vessels that were sealed tightly and weighed. After 7 days at $90^{\circ} \mathrm{C}$, the containers were removed from the oven, allowed to cool, weighed to determine water loss, and then opened. Due to the radioactivity of the glass, the initial portion of the test was performed remotely in a Shielded Cell using manipulators. The leachates from each vessel were then decanted into a clean scintillation vial. The radioactivities of the leachates were low enough so they could be transported to a radiochemical hood where they could be handled directly. The $\mathrm{pH}$ of each leachate was measured and then filtered through a $0.45 \mu \mathrm{m}$ filter and acidified to 1 volume percent $\mathrm{HNO}_{3}$. The leachates were then diluted and submitted to $\mathrm{AD}$, where the concentrations of $\mathrm{B}, \mathrm{Na}, \mathrm{Li}$, and $\mathrm{Si}$, were determined using ICP-AES.

\subsubsection{Glass Density Measurement}

The density of the SB6 Qualification Glass was measured using a pycnometry technique remotely in the Shielded Cells. A graduated cylinder was calibrated at multiple volume marks for measured weight of DI water. This same graduated cylinder was used for the density measurements. Small pieces of glass were added to the empty cylinder and the total dry mass was recorded. Incremental additions of water were added to the cylinder with the glass, total volume noted, and total mass recorded after each addition of water. Three water additions were recorded and used to calculate the density of the glass.

\subsection{Results and Discussion}

This section is divided into three major parts: 1) sludge washing, 2) DWPF Chemical Process Cell Simulation, and 3) glass fabrication and durability testing. 
SRNL-STI-2010-00353

Revision 0

\subsection{Sludge Washing}

The SRNL Tank 51 SB6 qualification sample was washed per Tank Farm plans of November 10, 2009 ${ }^{9}$. A mass balance showing wash, decant, and sample amounts is given in Appendix B.

The as-received and final washed sludge was characterized (elemental analyses, weight \% solids, supernate analyses). Densities, anions, and elementals of each decant were measured. More extensive characterization (weight \% solids, aqua regia digestions of slurry) was completed after Decants $\mathrm{C}$ and $\mathrm{F}$ to ensure washing was progressing as planned (e.g., no excessive dissolving or precipitation of solids, sulfur removal from solids). Decant $\mathrm{C}$ was chosen because a Pu stream was added during Washes B and C. Decant $\mathrm{F}$ was chosen because Wash $\mathrm{F}$ included a sodium nitrite addition for corrosion control.

Key analytical results (density, weight percent solids, selected supernate constituents, and major elementals in total solids) are presented in Table 3-1 and Table 3-2. Additional results can be found in Appendix C. Washing (decant) results are presented graphically in Figure 3-1.

The results show that washing proceeded as expected. Soluble species concentrations decreased (both in the supernate and in the total solids), and insoluble species concentrations increased (in the total solids). It should be noted that the mercury result from Post Decant $\mathrm{C}$ is lower than expected based on $\mathrm{Fe}$ to $\mathrm{Hg}$ ratios. Both elements are primarily insoluble in the caustic sludge. Therefore the ratio should be nearly content. However, $\mathrm{Fe}$ to $\mathrm{Hg}$ for wash $\mathrm{C}$ is less than 2.5 as compared to over 3 for the other analyses.

The results also show that aluminum is partially soluble. During washing, the aluminum in the supernate decreased (similar to sodium), but its concentration in the total solids initially decreased, but then increased after Decant $\mathrm{C}$.

In comparing slopes in Figure 3-1, it appears that the slope for sulfur and sulfate is less than the slopes for sodium, nitrite, nitrate, and aluminum (from As-Received to Decant C). This suggests that a portion of undissolved sulfur is dissolving during washing.

During washing, about $15 \%$ of the total $\mathrm{S}$ as an undissolved species was observed (see Figure 3-2). Note that "undissolved" does not imply that this S cannot dissolve during washing operations; it just indicates that it was not soluble under the current sludge conditions. It can also be seen in Figure 3-2 that there is a small, but consistent difference between the soluble S from ICP-AES and the soluble sulfate by IC, expressed in the figure on a molar basis, for the SB6 Qualification sample during washing. This difference averaged $17.5 \%$ across the eight washes, but the as-received material did not show any difference between soluble $\mathrm{S}$ and sulfate. Hence the difference in soluble $\mathrm{S}$ and sulfate seen during sludge batch washing appears to be due to the contribution of S from the HM sludge rather than the PUREX sludge. 
SRNL-STI-2010-00353

Revision 0

Table 3-1. Major Elements in the Tank 51 SB6 Qualification Sample ${ }^{\dagger}$

\begin{tabular}{|c|c|c|c|c|}
\hline & As-Received & Post Decant C & Post Decant F & $\begin{array}{c}\text { Post Decant I } \\
\text { (SB6 SRAT } \\
\text { Receipt) }\end{array}$ \\
\hline Element & \multicolumn{4}{|c|}{ Wt \% of Total Solids } \\
\hline $\mathrm{Al}$ & 6.01 & 5.98 & 7.81 & 11.0 \\
\hline $\mathrm{Ca}$ & 0.140 & 0.242 & 0.357 & 0.527 \\
\hline $\mathrm{Fe}$ & 2.87 & 4.80 & 7.76 & 11.8 \\
\hline $\mathrm{Hg}$ & 0.872 & 2.05 & 2.06 & 3.12 \\
\hline $\mathrm{K}$ & 0.117 & $<0.1$ & $<0.1$ & $<0.1$ \\
\hline $\mathrm{Mg}$ & $<0.1$ & $<0.1$ & 0.144 & 0.214 \\
\hline $\mathrm{Mn}$ & 1.02 & 1.75 & 2.79 & 4.15 \\
\hline $\mathrm{Na}$ & 30.2 & 29.5 & 24.9 & 15.4 \\
\hline $\mathrm{Ni}$ & 0.415 & 0.677 & 1.12 & 1.69 \\
\hline $\mathrm{P}$ & $<0.1$ & $<0.1$ & 0.118 & 0.143 \\
\hline $\mathrm{S}$ & 1.04 & 0.785 & 0.663 & 0.375 \\
\hline $\mathrm{Si}$ & 0.178 & $\mathrm{NM}$ & NM & 0.711 \\
\hline $\mathrm{Th}$ & 0.731 & NM & NM & 2.98 \\
\hline $\mathrm{U}$ & 0.601 & 1.11 & 1.73 & 2.46 \\
\hline $\mathrm{Zr}$ & $<0.1$ & $<0.1$ & 0.129 & 0.156 \\
\hline
\end{tabular}

$\mathrm{NM}=$ not measured. Only aqua regia digestions were performed after Decants $\mathrm{C}$ and $\mathrm{F}$. Aqua regia is not an appropriate digestion for Si. Also, the digestions were not submitted for ICP-MS analysis, the method for Th quantification.

${ }^{\dagger}$ Major elements are those detected at a concentration of greater than $0.1 \mathrm{wt} \%$ of total solids. 
Table 3-2. Weight Percent Solids and Selected Supernate Constituents Measured During SB6 Washing

\begin{tabular}{|c|c|c|c|c|c|c|c|c|c|}
\hline Parameter & As-Rcvd & Decant B & Decant C & Decant D & Decant E & Decant F & Decant G & Decant $\mathbf{H}$ & Decant I \\
\hline Supernate Density (kg/L) & 1.36 & 1.26 & 1.20 & 1.15 & 1.12 & 1.11 & 1.08 & 1.06 & 1.06 \\
\hline Slurry Density $(\mathrm{kg} / \mathrm{L})$ & 1.38 & NM & 1.27 & NM & NM & 1.17 & NM & NM & 1.13 \\
\hline Total Solids (wt $\%$ of slurry) & 38.01 & NM & 26.51 & NM & NM & 17.57 & NM & NM & 15.12 \\
\hline $\begin{array}{l}\text { Dissolved Solids (wt } \% \text { of } \\
\text { supernatant) }\end{array}$ & 34.03 & NM & 21.56 & NM & NM & 11.29 & NM & NM & 5.80 \\
\hline $\begin{array}{l}\text { Insoluble Solids (wt } \% \text { of } \\
\text { slurry) }\end{array}$ & 6.04 & NM & 6.31 & NM & NM & 7.08 & NM & NM & 9.89 \\
\hline $\begin{array}{l}\text { Soluble Solids (wt } \% \text { of } \\
\text { slurry) }\end{array}$ & 31.98 & NM & 20.20 & NM & NM & 10.49 & NM & NM & 5.23 \\
\hline $\begin{array}{l}\text { Calcined Solids (wt } \% \text { of } \\
\text { slurry) }\end{array}$ & 25.60 & $\mathrm{NM}$ & NM & $\mathrm{NM}$ & $\mathrm{NM}$ & 13.22 & NM & NM & 11.89 \\
\hline Sodium (M) & 8.55 & 6.09 & 4.41 & 3.25 & 2.45 & 2.14 & 1.62 & 1.28 & 1.08 \\
\hline Nitrate $(\mathrm{M})$ & 1.27 & 0.756 & 0.493 & 0.449 & 0.285 & 0.213 & 0.236 & 0.144 & 0.124 \\
\hline Sulfate $(\mathrm{M})^{\dagger}$ & 0.184 & 0.0980 & 0.0676 & 0.0485 & 0.0421 & 0.0290 & 0.0219 & 0.0174 & 0.015 \\
\hline Sulfur $(\mathrm{M})^{\dagger}$ & 0.181 & 0.110 & 0.073 & 0.058 & 0.049 & 0.037 & 0.0272 & 0.0174 & 0.018 \\
\hline Aluminum (M) & 0.798 & 0.485 & 0.355 & 0.258 & 0.190 & 0.153 & 0.117 & 0.091 & 0.075 \\
\hline
\end{tabular}

Sulfate was determined from IC analysis, while sulfur was determined from ICP-AES analysis. 
SRNL-STI-2010-00353

Revision 0

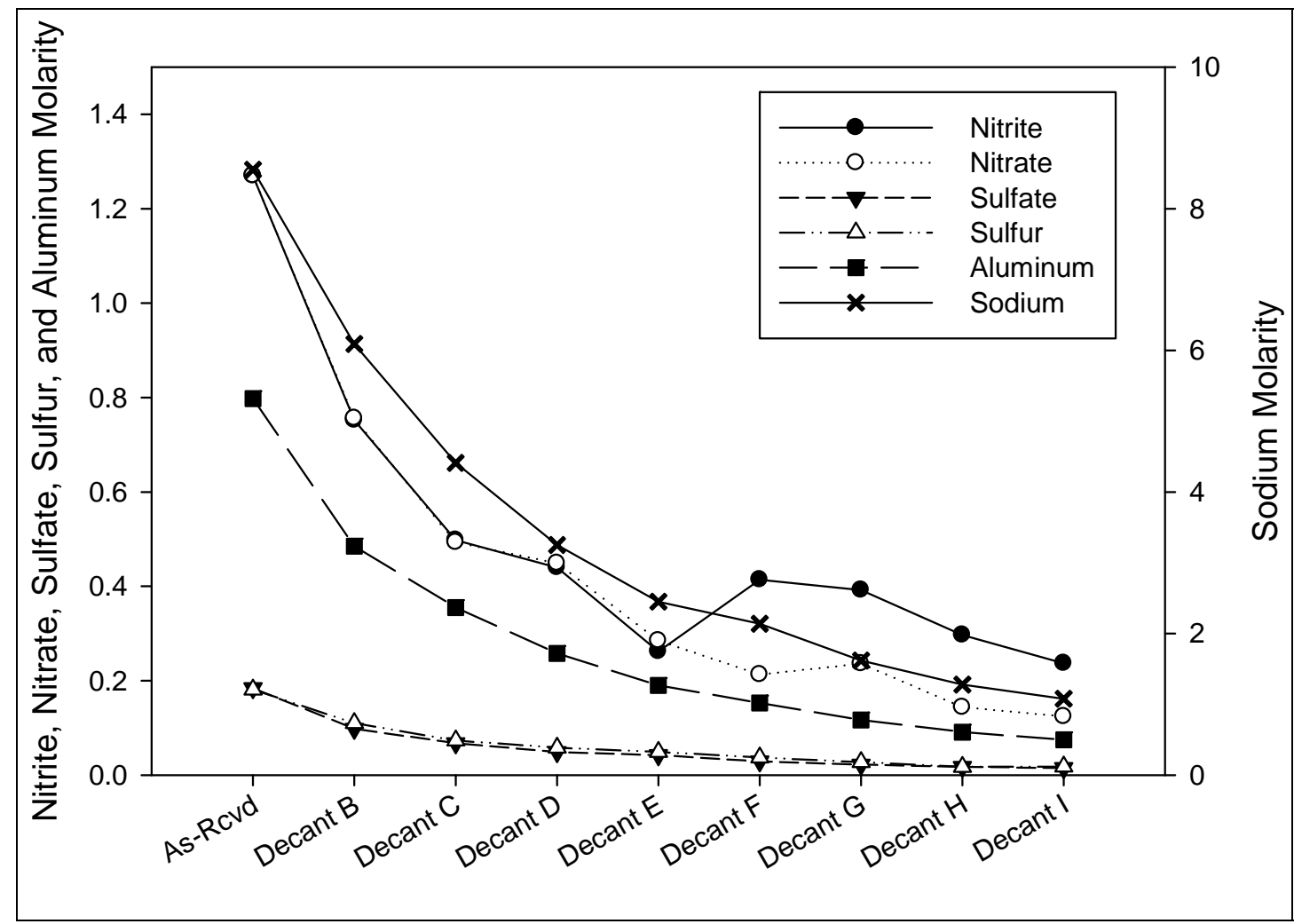

Figure 3-1. Graphical Presentation of Major Supernate Constituents

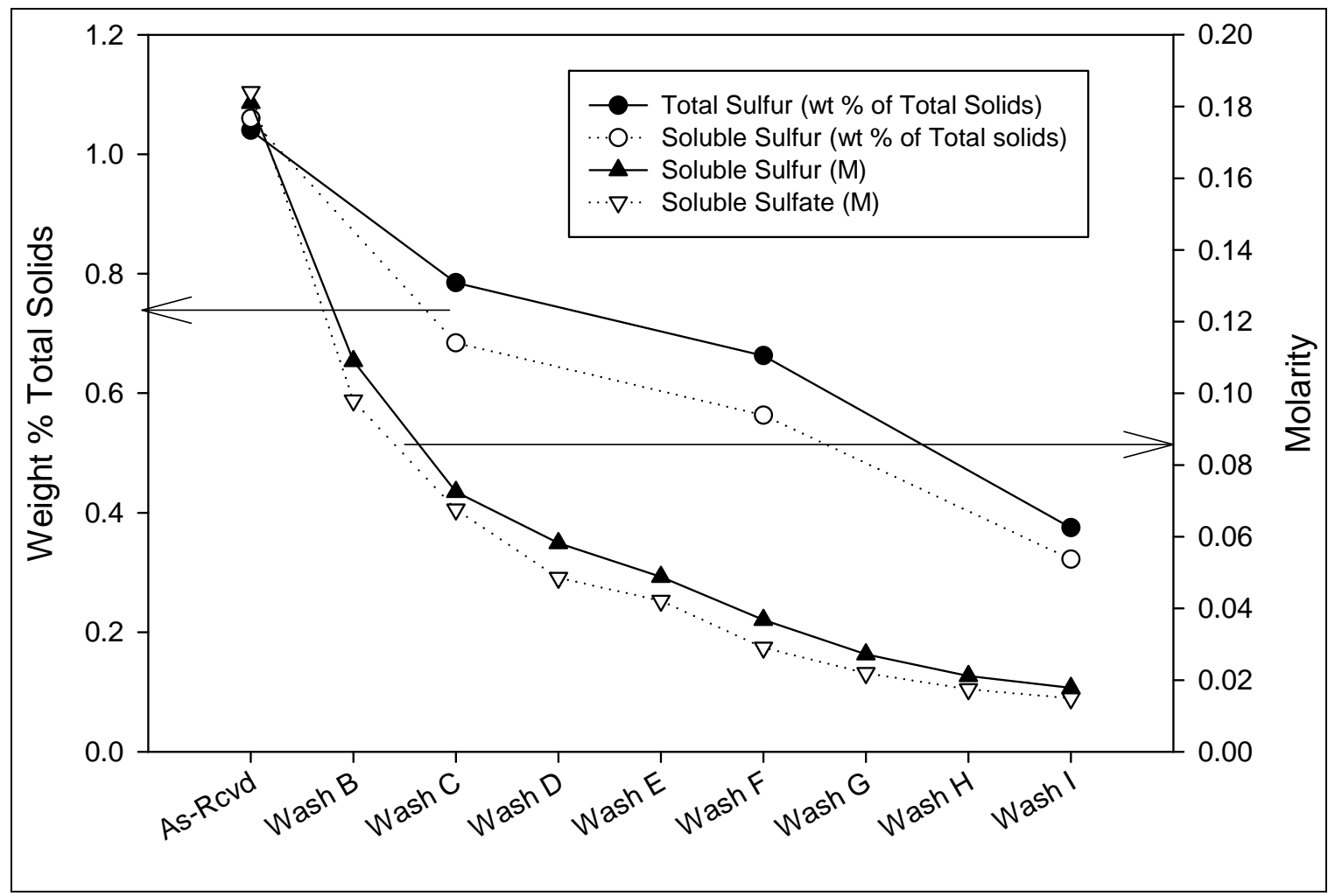

Figure 3-2. Graphical Presentation of Sulfur and Sulfate During Washing 
Presented in Table 3-3 are the measured noble metals and other elements specifically requested in the TTR in the washed Tank 51 SB6 (SRAT receipt) solids. Noble metals catalyze hydrogen generation in the SRAT and SME cycles, giving qualitative guidance on SRAT acid stoichiometry.

Table 3-3. SRAT Receipt Tank 51 SB6 Qualification Sample Noble Metals and Minor Elements

\begin{tabular}{||l|c|l|c||}
\hline Element & $\begin{array}{c}\text { Wt \% of Total } \\
\text { Solids }\end{array}$ & Element & $\begin{array}{c}\text { Wt \% of Total } \\
\text { Solids }\end{array}$ \\
\hline $\mathrm{Ru}$ & 0.0924 & $\mathrm{Cr}$ & 0.0448 \\
\hline $\mathrm{Rh}$ & 0.0187 & $\mathrm{Co}$ & 0.00869 \\
\hline $\mathrm{Pd}$ & 0.00304 & $\mathrm{Cu}$ & 0.0711 \\
\hline $\mathrm{Ag}$ & 0.0138 & $\mathrm{~Pb}$ & 0.0158 \\
\hline $\mathrm{As}$ & $<0.0010$ & $\mathrm{Sb}$ & $<0.014$ \\
\hline $\mathrm{Ba}$ & 0.0917 & $\mathrm{Se}$ & $<0.0021$ \\
\hline $\mathrm{Be}$ & $<0.00074$ & $\mathrm{Ti}$ & 0.0164 \\
\hline $\mathrm{Cd}$ & 0.00799 & & \\
\hline
\end{tabular}

Anions, total inorganic carbon, and total base are required for SRAT acid calculations. These results are presented in Table 3-4 and Table 3-5.

Table 3-4. SRAT Receipt Tank 51 SB6 Qualification Sample Anions and Carbon

\begin{tabular}{||l|c||}
\hline Analyte & mg/kg slurry \\
\hline Bromide & $<100$ \\
\hline Chloride & $<100$ \\
\hline Fluoride & $<100$ \\
\hline Formate & 6,840 \\
\hline Nitrate & 10,000 \\
\hline Nitrite & $<100$ \\
\hline Oxalate & $<100$ \\
\hline Phosphate & 1200 \\
\hline Sulfate & 913 \\
\hline $\begin{array}{l}\text { Total Inorganic } \\
\text { Carbon }\end{array}$ & 483 \\
\hline $\begin{array}{l}\text { Total Organic } \\
\text { Carbon }\end{array}$ & 1400 \\
\hline Total Carbon & \\
\hline
\end{tabular}


Table 3-5. SRAT Receipt Tank 51 SB6 Qualification Sample Total Base, Free Hydroxide, and Other Bases Excluding Carbonate

\begin{tabular}{|l|c||}
\hline Analyte & $\begin{array}{c}\text { Mol/L } \\
\text { Slurry }\end{array}$ \\
\hline Total Base & 0.58 \\
\hline Free $\mathrm{OH}^{-}$ & 0.40 \\
\hline $\begin{array}{l}\text { Other Base } \\
\text { Excluding } \mathrm{CO}_{3}{ }^{2-}\end{array}$ & 0.12 \\
\hline
\end{tabular}

Slurry samples were prepared and submitted for VOA and SVOA analysis. No VOA or SVOA analytes were detected.

Sludge level was recorded during settling. These results are presented graphically in Figure 3-3. Observations (time, sludge level) are shown in Appendix E. The observations have been normalized (observed sludge level/starting sludge level for each wash) for comparison. It should be noted that Decant A, from the as-received Tank 51 sample was a relatively small decant. Sludge from Tank 4 (already present in the SRNL sample), not wash water, was added to Tank 51 prior to this decant. Thus, settling was not expected to be similar to the other washes. See Appendix A for the Tank Farm washing strategy which SRNL simulated. It appears that settling rate increased during washing up to Decant D. Settling during the remaining washes was comparable.

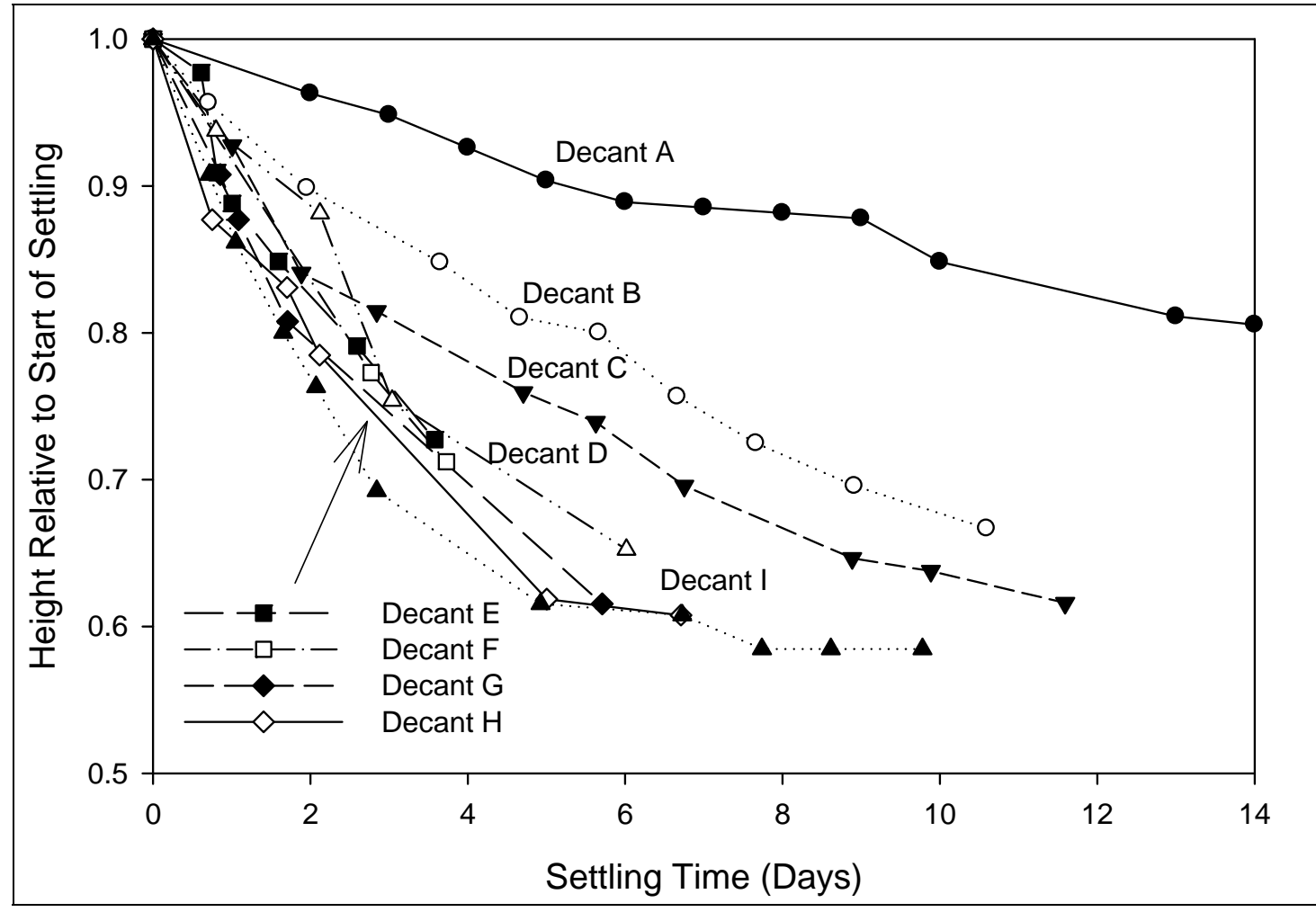

Figure 3-3. Setting During Washing. 
SRNL-STI-2010-00353

Revision 0

\subsection{Chemical Process Cell Simulation}

\subsubsection{SRAT Cycle Results and Discussion}

Following washing of the Tank 51 SB6 qualification sample, the material was used in DWPF CPC simulations. The initial step of the simulations is the acid calculation to estimate the required acid necessary to complete reactions. This calculation uses

measured analytical inputs. Errors in these measurements can result in too little acid being added resulting in incomplete reactions or too much acid being added resulting in excess formic acid causing high hydrogen generation rates. Analytical results of the SRAT receipt sample are given in Section 3.1. All inputs for the acid calculation are presented in Table 3-6. The non measured inputs (for example, acid stoichiometric factor, formic acid destruction, etc.) were based on simulant tests. ${ }^{2}$ Note that characterization results of the SRAT receipt sample are presented in Section 3.1. 
SRNL-STI-2010-00353

Revision 0

Table 3-6. Acid Calculation Inputs for the Tank 51 SB6 Qualification CPC Simulation

\begin{tabular}{|c|c|c|}
\hline Measurement/Assumption & Units & Result \\
\hline Total Solids & wt $\%$ of slurry & 15.12 \\
\hline Insoluble Solids & $\mathrm{wt} \%$ of slurry & 9.89 \\
\hline Soluble Solids & $\mathrm{wt} \%$ of slurry & 5.23 \\
\hline Calcined Solids & $\mathrm{wt} \%$ of slurry & 11.89 \\
\hline Slurry Density & $\mathrm{g} / \mathrm{mL}$ slurry & 1.13 \\
\hline Supernatant Density & $\mathrm{g} / \mathrm{mL}$ supernatant & 1.06 \\
\hline $\mathrm{Hg}$ & $\mathrm{wt} \%$ of total solids & 3.12 \\
\hline $\mathrm{Mn}$ & $\mathrm{wt} \%$ of calcined solids & 5.28 \\
\hline Nitrite & $\mathrm{mg} / \mathrm{kg}$ slurry & 10,000 \\
\hline Nitrate & $\mathrm{mg} / \mathrm{kg}$ slurry & 6,840 \\
\hline Formate & $\mathrm{mg} / \mathrm{kg}$ slurry & 100 \\
\hline TIC & $\mathrm{mg} / \mathrm{kg}$ slurry & 913 \\
\hline Total Base & $\mathrm{mol} / \mathrm{L}$ slurry to $\mathrm{pH}=7$ & 0.582 \\
\hline $\begin{array}{l}\text { Conversion of Nitrite to Nitrate in } \\
\text { SRAT Cycle }\end{array}$ & gmol $\mathrm{NO}_{3}{ }^{-} / 100$ gmol NO$_{2}^{-}$ & -10 \\
\hline $\begin{array}{l}\text { Destruction of Nitrite in SRAT } \\
\text { and SME cycle }\end{array}$ & $\%$ of starting nitrite & 100 \\
\hline $\begin{array}{l}\text { Destruction of Formic acid } \\
\text { charged in SRAT }\end{array}$ & $\%$ of total formate & 32 \\
\hline $\begin{array}{l}\text { Percent Acid in Excess of } \\
\text { Stoichiometric Ratio }\end{array}$ & $\%$ & 115 \\
\hline $\begin{array}{l}\text { SRAT Product Target Total } \\
\text { Solids }\end{array}$ & $\mathrm{wt} \%$ of SRAT Product & 25 \\
\hline Predicted and/or Target REDOX & $\mathrm{Fe}^{+2} / \Sigma \mathrm{Fe}$ & 0.2 \\
\hline $\begin{array}{l}\text { No. of basis antifoam additions } \\
\text { added during SRAT cycle }\end{array}$ & N/A & 10 \\
\hline $\begin{array}{l}\text { Destruction of Formic acid in } \\
\text { SME }\end{array}$ & $\begin{array}{l}\% \text { of SRAT Product } \\
\text { formate } \\
\end{array}$ & 5 \\
\hline Destruction of Nitrate in SME & $\begin{array}{c}\% \text { of SRAT Product } \\
\text { nitrate }\end{array}$ & 5 \\
\hline Assumed SME density & $\mathrm{g} / \mathrm{mL}$ slurry & 1.25 \\
\hline $\begin{array}{l}\text { No. of basis antifoam additions } \\
\text { added during SME cycle }\end{array}$ & $\mathrm{N} / \mathrm{A}$ & 10 \\
\hline $\begin{array}{l}\text { Sludge Oxide Contribution in } \\
\text { SME (Waste Loading) }\end{array}$ & $\%$ sludge oxides & 34 \\
\hline SME Product Target Total Solids & $\mathrm{wt} \%$ of SME Product & 45 \\
\hline
\end{tabular}

The primary results of the acid calculation (the acid requirements) are presented in Table 3-7. Note that DWPF reviewed the acid calculation. 
Table 3-7. SRAT Cycle Acid Requirements

\begin{tabular}{||l|c|}
\hline Parameter & Value \\
\hline $\begin{array}{c}\text { Calculated Stoichiometric Acid (100\% } \\
\text { stoichiometry), moles/L }\end{array}$ & 1.12 \\
\hline $\begin{array}{c}\text { Actual Acid to Add ( stoichiometric } \\
\text { amount x \% excess acid), moles/L }\end{array}$ & 1.29 \\
\hline Ratio of Formic Acid to Total Acid & 0.89 \\
\hline
\end{tabular}

The SRNL Tank 51 SB6 SRAT cycle (designated as SC-9 SRAT Cycle) began on February 22, 2010. The cycle began by concentrating the SRAT receipt material from $9.9 \mathrm{wt} \%$ insoluble solids to a target of $12 \mathrm{wt} \%$ insoluble solids by boiling and removing water. Foaming was constant during caustic boiling. $700 \mathrm{ppm}$ of antifoam was added during the five hours of boiling/concentration to keep the foam from reaching the top of the vessel. Based on a mass balance calculation, the SRAT material was concentrated to $12.7 \mathrm{wt} \%$ insoluble solids. At the completion of caustic boiling, acid addition began. Nitric acid was completed without incident, but major foaming occurred approximately two thirds of the way into formic acid addition. Because of the loss of material in the foaming incident, the cycle was suspended, the remaining material was removed and the mass determined, the remaining amount of formic acid to add was recalculated, and a new SRAT/SME apparatus was installed.

The formic acid addition for the SRAT cycle resumed with the remaining material and the new apparatus on March 3, 2010. The SRAT product was concentrated to a target of $25 \mathrm{wt} \%$ total solids, and the contents were boiled at reflux for 35 hours at a DWPF-scaled bolup rate of 2,500 lb/h steam (see below for a discussion of $\mathrm{Hg}$ removal and boilup rate). Foaming was not observed during the conclusion of formic acid addition. Foaming was observed, but was not excessive during boiling. Antifoam addition times and amounts after the completion of acid addition are given in Table 3-9.

Table 3-8. Antifoam Additions During Caustic Boiling/Concentration

\begin{tabular}{|c|c|}
\hline $\begin{array}{c}\text { Time Relative to Start of } \\
\text { Boiling (h:mm) }\end{array}$ & $\begin{array}{c}\text { Antifoam } \\
\text { Addition (ppm) }\end{array}$ \\
\hline $0: 00$ & 200 \\
\hline $0: 15$ & 100 \\
\hline $0: 35$ & 100 \\
\hline $1: 50$ & 100 \\
\hline $2: 15$ & 100 \\
\hline $3: 00$ & 100 \\
\hline $4: 45$ & $\begin{array}{c}\text { Dewater } \\
\text { Complete }\end{array}$ \\
\hline
\end{tabular}


SRNL-STI-2010-00353

Revision 0

Table 3-9. Antifoam Additions After Formic Acid Addition

\begin{tabular}{|c|c||}
\hline $\begin{array}{c}\text { Time Relative to } \\
\text { Completion of Formic Acid } \\
\text { Addition (h) }\end{array}$ & $\begin{array}{c}\text { Antifoam } \\
\text { Addition (ppm) }\end{array}$ \\
\hline 0 & 600 \\
\hline 8 & 100 \\
\hline 12.5 & 100 \\
\hline 13.5 & 100 \\
\hline 21.5 & 100 \\
\hline 28.5 & 100 \\
\hline
\end{tabular}

Following the SRAT Cycle, an analytical sample was pulled, and the sample was characterized with results given in Table 3-10. Results show that nitrite was destroyed to less than $1,000 \mathrm{mg} / \mathrm{kg}$, but mercury was not removed to the DWPF target of $0.6 \mathrm{wt} \%$ of the total solids.

After re-checking the SRNL acid calculations, it was discovered that the boilup rate was scaled to $2,500 \mathrm{lb} / \mathrm{h}$ steam, which had been used in a previous radioactive run to simulate DWPF's lower boil-up rate, instead of the design basis of 5,000 lb/h. Therefore, prior to the SME cycle, the sludge was boiled under reflux to remove additional mercury (nine hours at a scaled boilup rate of 5,000 lb/h).

Based on boiling at half the design boilup rate, the mercury would be expected to be approximately $1.5 \mathrm{wt} \%$ of the total solids. The measured result was lower $-1.1 \mathrm{wt} \%$ of the total solids, yielding s steam stripping rate of slightly more than the predicted $750 \mathrm{~g}$ steam $/ \mathrm{g} \mathrm{Hg}$. Additional reflux time, at the DWPF rate of 5,000 lb/h, was calculated to reach the target of $0.6 \mathrm{wt} \%$ of total solids ( $750 \mathrm{~g}$ steam $/ \mathrm{g}$ mercury). Following the reflux time (prior to the SME cycle), a sample was pulled. The result was $0.59 \mathrm{wt} \%$ mercury in the total solids. These results are consistent with expectations - mercury removal rate decreases slightly as mercury is removed. These results also show that $750 \mathrm{~g}$ of steam per $g$ of mercury is adequate for mercury removal. Note that the vessel was purged at a scaled SME purge rate since the SME was begun immediately after this reflux time; the off-gas is presented in the SME cycle section, specifically Figure 3-6.

In addition to primary anions, SRNL analyzed the SRAT product for ammonium. SRNL also analyzed the SRAT dewater for ammonium. None was detected $(<200 \mathrm{mg} / \mathrm{kg})$. 
SRNL-STI-2010-00353

Revision 0

Table 3-10. Characterization Results of the SB6 Qualification SRAT Product

\begin{tabular}{|c|c|}
\hline Analysis & Result \\
\hline Weight \% Total Solids (slurry basis) & 25.9 \\
\hline Weight $\%$ Dissolved Solids (supernate basis) & 9.35 \\
\hline Weight \% Insoluble Solids (slurry basis) & 18.3 \\
\hline Weight $\%$ Soluble Solids (slurry basis) & 7.6 \\
\hline Weight \% Calcined Solids (slurry basis) & 17.7 \\
\hline Slurry Density $(\mathrm{g} / \mathrm{mL})$ & 1.23 \\
\hline Supernate Density $(\mathrm{g} / \mathrm{mL})$ & 1.06 \\
\hline $\mathrm{pH}$ & 10 \\
\hline Fluoride (mg/kg slurry) & $<1,000$ \\
\hline Formate (mg/kg slurry) & 43,600 \\
\hline Chloride (mg/kg slurry) & $<1,000$ \\
\hline Nitrite (mg/kg slurry) & $<1,000$ \\
\hline Nitrate (mg/kg slurry) & 26,200 \\
\hline Phosphate (mg/kg slurry) & $<100$ \\
\hline Sulfate (mg/kg slurry) & 2,370 \\
\hline Oxalate (mg/kg slurry) & $<100$ \\
\hline Ammonium (mg/kg slurry) & $<200$ \\
\hline Total Carbon (mg/kg slurry) $^{\dagger}$ & 17,400 \\
\hline Total Inorganic Carbon (mg/kg slurry) & 1,800 \\
\hline Total Organic Carbon (mg/kg slurry) & 15,600 \\
\hline Mercury (wt $\%$ of total solids) & 1.1 \\
\hline
\end{tabular}

Off-gas data are presented in Table 3-11 (peak generation rates and concentrations), Figure 3-4 (off-gas during caustic boiling and acid addition up to the foam-over event), and Figure 3-5 (offgas during the completion of formic acid addition through the completion of the SRAT cycle). As expected, there was very little gas generation during boiling/concentration. Carbon dioxide and nitrous oxide generation began when nitric acid began. Peak carbon dioxide generation was observed just prior to the foam-over event. Carbon dioxide and nitrous oxide generation continued when the SRAT cycle (and formic acid addition) was resumed Several hours after nitrite destruction, as evidenced by the drop in nitrous oxide generation, hydrogen generation increased to a peak, and then slowly declined. 
SRNL-STI-2010-00353

Revision 0

Table 3-11. SB6 Qualification SRAT Cycle Maximum Observed Hydrogen, Carbon Dioxide, and Nitrous Oxide DWPF Scale Concentrations and Generation Rates

\begin{tabular}{||c|c|c||}
\hline Gas & $\begin{array}{c}\text { Maximum Gas } \\
\text { Concentration } \\
\text { (vol\%) }\end{array}$ & $\begin{array}{c}\text { Maximum Gas } \\
\text { Generation Rate } \\
\text { (DWPF lb/h) }\end{array}$ \\
\hline Hydrogen & 0.75 & 0.55 \\
\hline Carbon Dioxide & $23.4^{\dagger}$ & $506^{\dagger}$ \\
\hline Nitrous Oxide & 1.00 & 17.2 \\
\hline
\end{tabular}

${ }^{\dagger}$ This generation rate and concentration was observed just prior to the foaming event. The peak carbon dioxide generation rate was increasing; thus, this value may not represent the maximum carbon dioxide generation rate. 
SRNL-STI-2010-00353

Revision 0

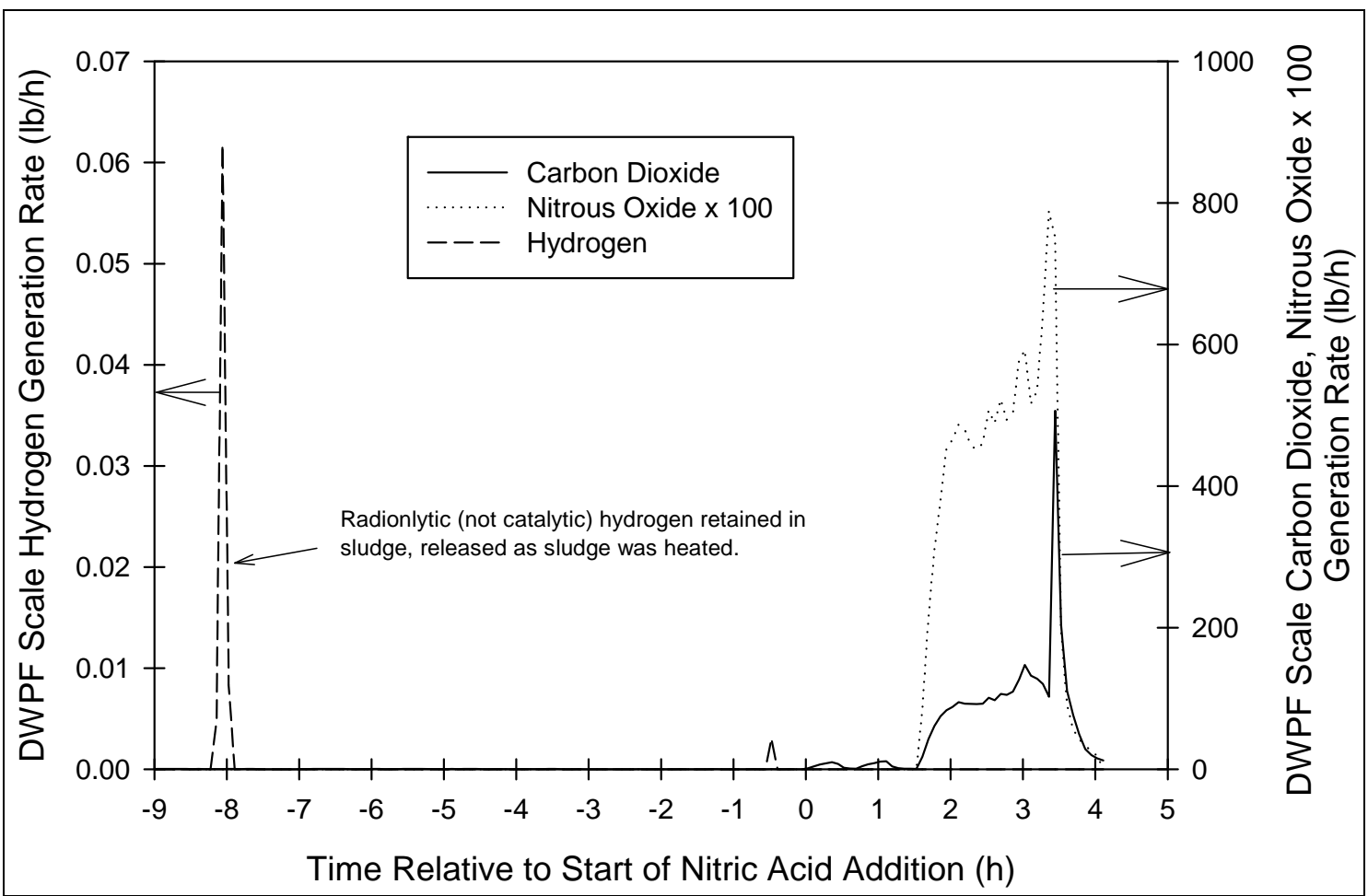

a

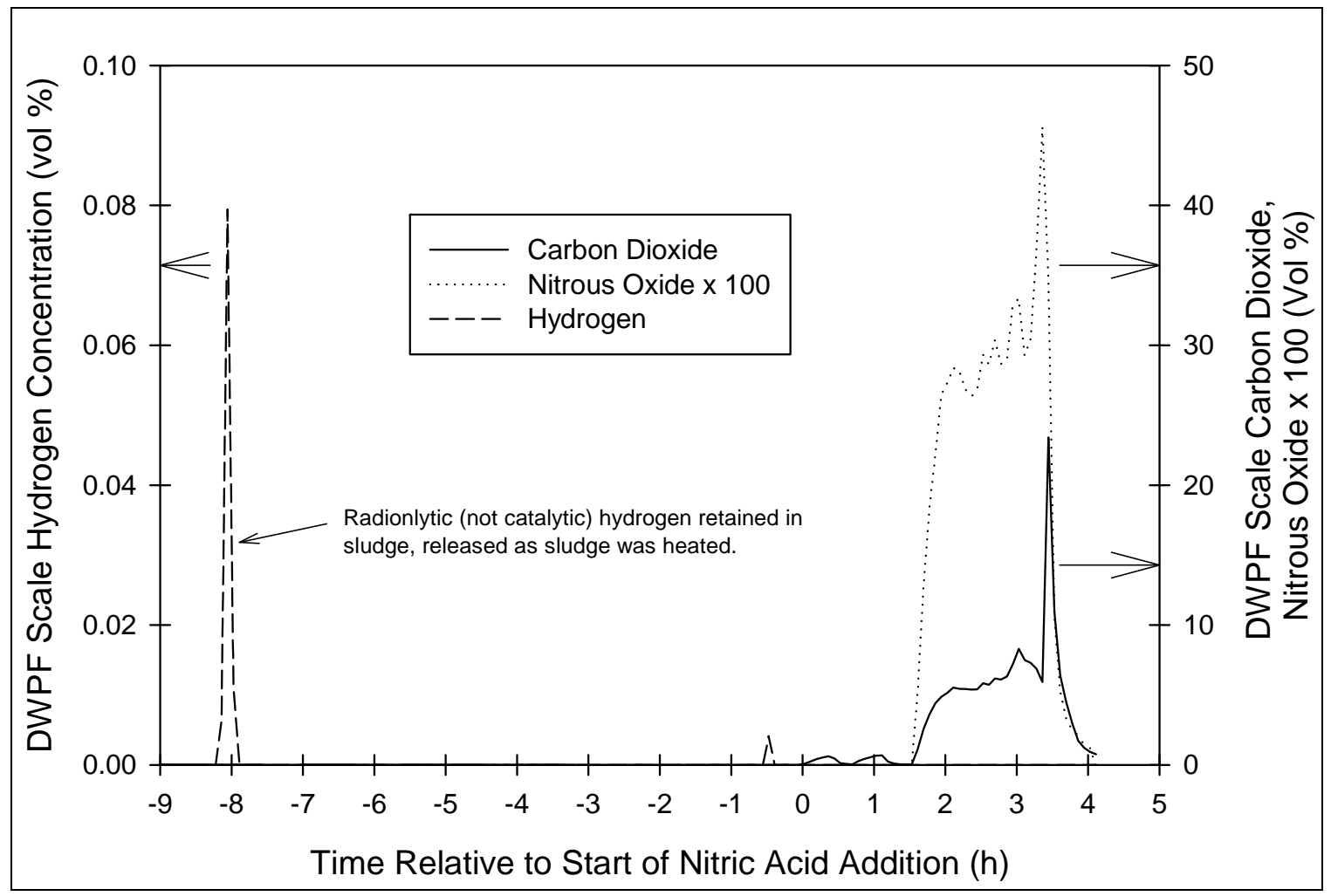

b

Figure 3-4. Plot of Gas Generation Rates (a) and Concentrations (b) During Caustic Boiling/Concentration and During Acid Addition Prior to Foaming Event 


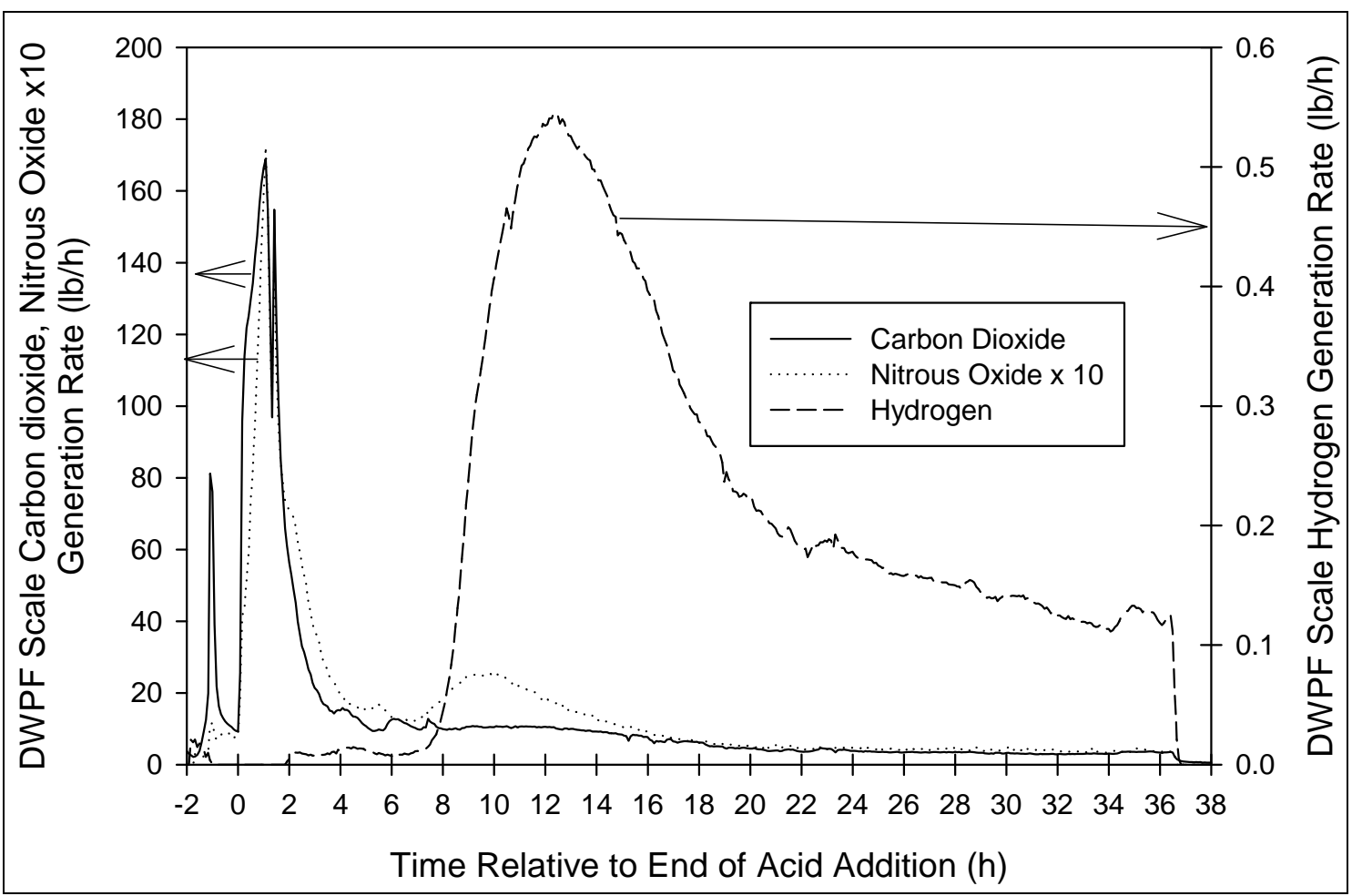

a



b

Figure 3-5. Plot of Gas Generation Rates (a) and Concentrations (b) Following Restart After Foam Over Event 


\subsubsection{SME Cycle Results and Discussion}

The SRNL SB6 Qualification SME cycle began on March 18, 2010 with $470 \mathrm{~g}$ of SRAT product (based on mass balance calculations). Prior to the SME cycle, the SRAT product was boiled under reflux approximately nine hours to remove additional mercury. The SME cycle consisted of the addition and removal of water to simulate the addition and removal of decon water for five glass canisters (water was added and then boiled off five times). Frit 418 was then added in two equal batches (148 $\mathrm{g}$ total) along with an equivalent mass of water and formic acid (98.5 wt \% water, $1.5 \mathrm{wt} \%$ formic acid). Frit addition was based on a target waste loading of $35 \mathrm{wt} \%$ calcined sludge. A sample of the SME product was vitrified, and the resulting glass was characterized and evaluated using the PCT.

The following observations were made during the SME cycle:

- An evaluation of mixing was not possible due to the small quantity of material. However, constant temperature during boiling and the absence of offgas spikes suggest that mixing was adequate.

- Excessive foaming was not observed during the SME cycle. 100 ppm antifoam was added prior to the SME cycle (during boiling under reflux to steam strip mercury). No additional antifoam was added throughout the SME cycle.

The SME product total solids was measured to be $52.5 \mathrm{wt} \%$. The material was extremely thick and sticky; making sampling difficult. Therefore, condensate from the final SME dewater was added to the SME product to lower the total solids to $45 \mathrm{wt} \%$ (the targeted wt \% total solids). At this lower total solids, sampling remained difficult. Because of limitations on the amount of SME product, its thickness, and its stickiness, supernate for dissolved solids and supernate density was not taken. Also, rheological measurements were not performed. The limited characterization data for the SME product at $52.5 \mathrm{wt} \%$ total solids (weight \% total solids, weight percent calcined solids, and the calcine factor) is presented in Table 3-12.

Table 3-12. Physical Properties of As-Made SB6 SME Product (Prior to Dilution to 45 wt \% Total Solids)

\begin{tabular}{|c|c|}
\hline Property & Result \\
\hline Wt \% Total Solids & 52.5 \\
\hline Wt \% Calcined Solids & 46.9 \\
\hline $\begin{array}{c}\text { Calcine Factor (mass oxides/mass } \\
\text { total solids) }\end{array}$ & 0.89 \\
\hline Wt \% Dissolved Solids & \multirow{4}{*}{$\begin{array}{c}\text { NA - SME product } \\
\text { was too thick and } \\
\text { sticky for adequate } \\
\text { measurement. }\end{array}$} \\
\hline Wt \% Insoluble Solids & \\
\hline Wt \% Soluble Solids & \\
\hline Supernate Density & \\
\hline
\end{tabular}


Characterization results (density, anions, etc.) of the SME product after dilution with condensate to $45 \mathrm{wt} \%$ total solids are shown in Table 3-13. It is not surprising for total inorganic carbon to be detected in the SME product. The SRAT product had measurable total inorganic carbon (TIC) and was basic $(\mathrm{pH}=10)$. The $\mathrm{pH}$ of the SME product was not measured due to its thickness, but it would not be expected to be lower than the SRAT product.

\section{Table 3-13. SB6 SME Product (at 45 wt \% Total Solids) Density, Anion, and Cation Concentrations}

\begin{tabular}{|l|c|}
\hline Measurement & Result \\
\hline \hline Density, $\mathrm{T}=21^{\circ} \mathrm{C}(\mathrm{g} / \mathrm{L})$ & 1.42 \\
\hline Fluoride $(\mathrm{mg} / \mathrm{kg})$ & $<50$ \\
\hline Formate $(\mathrm{mg} / \mathrm{kg})$ & 26,300 \\
\hline Chloride $(\mathrm{mg} / \mathrm{kg})$ & $<50$ \\
\hline Nitrite $(\mathrm{mg} / \mathrm{kg})$ & 613 \\
\hline Bromide $(\mathrm{mg} / \mathrm{kg})$ & $<50$ \\
\hline Nitrate $(\mathrm{mg} / \mathrm{kg})$ & 15,500 \\
\hline Phosphate $(\mathrm{mg} / \mathrm{kg})$ & $<300$ \\
\hline Sulfate $(\mathrm{mg} / \mathrm{kg})$ & 1,450 \\
\hline Oxalate $(\mathrm{mg} / \mathrm{kg})$ & 147 \\
\hline Ammonium $(\mathrm{mg} / \mathrm{kg})$ & $<2,500$ \\
\hline Total Inorganic Carbon $(\mathrm{mg} / \mathrm{kg})$ & 1,800 \\
\hline Total Organic Carbon $(\mathrm{mg} / \mathrm{kg})$ & 10,200 \\
\hline Total Carbon $(\mathrm{mg} / \mathrm{kg})$ & 12,000 \\
\hline \hline
\end{tabular}

${ }^{\dagger}$ Because of the stickiness of the sample and difficulty in removing it from the density measurement container, the density measurement was not repeated. It should be noted that the measured density is similar to what one would expect for a $\sim 50 \mathrm{wt} \%$ total solids SME product.

$\$$ Total Carbon $=$ Total Inorganic Carbon + Total Organic Carbon

Peak offgas generation and a plot of gas generation during the SME cycle are presented in Table 3-14 and Figure 3-6, respectively. It should be noted that the SRAT product was boiled under reflux prior to the start of the SME cycle; offgas generation during this reflux period is shown, but is not considered part of the SME cycle. Peak hydrogen generation $(0.05 \mathrm{lb} / \mathrm{h}$, DWPF scale) was below the DWPF limit of $0.223 \mathrm{lb} / \mathrm{h}$. It is also noteworthy that hydrogen generation dropped drastically after the addition of decon water and never increased to the generation rate seen during the reflux time. The large vapor space in the SME vessel may have contributed to this. 
SRNL-STI-2010-00353

Revision 0

Table 3-14. SB6 SME Cycle Maximum Observed Hydrogen, Carbon Dioxide, and Nitrous Oxide DWPF Scale Concentrations and Generation Rates

\begin{tabular}{|c|c|c||}
\hline Gas & $\begin{array}{c}\text { Maximum Gas } \\
\text { Concentration } \\
\text { (vol\%) }\end{array}$ & $\begin{array}{c}\text { Maximum Gas } \\
\text { Generation Rate } \\
\text { (DWPF lb/h) }\end{array}$ \\
\hline \hline Hydrogen & 0.19 & 0.05 \\
\hline Carbon Dioxide & 5.9 & 34 \\
\hline Nitrous Oxide & 0.051 & 0.27 \\
\hline
\end{tabular}

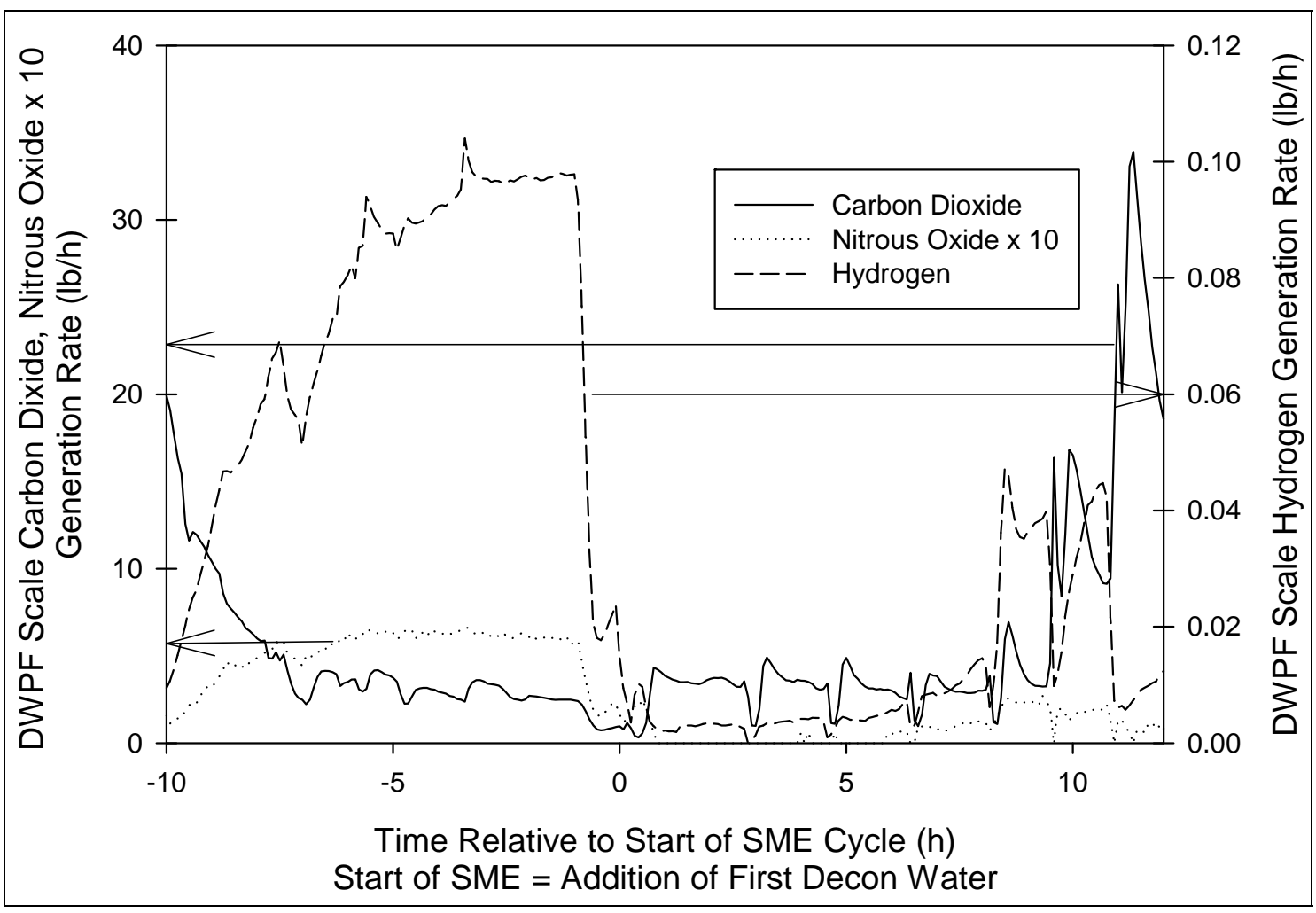

Figure 3-6. Offgas Data from the SB6 Qualification SME Cycle

\subsubsection{Rheology of CPC Materials}

Rheology results of the SRAT receipt and SRAT product material are presented in Table 3-15. As can be seen, concentration of the SRAT receipt material increased the yield stress to $12 \mathrm{~Pa}$, higher than the design basis. This may be of concern in SB6 processing since rheology was not improved in the SRAT cycle. Therefore, SRNL does not recommend concentration prior to the SRAT cycle until further testing can be performed to define a more optimal endpoint. 
SRNL-STI-2010-00353

Revision 0

Table 3-15. SB6 SRAT Receipt Slurry Rheology Data Before and After Concentration plus SRAT Product Rheology Data

\begin{tabular}{|c|c|c|c|}
\hline Sample & $\begin{array}{c}\text { Wt\% Total } \\
\text { Solids }\end{array}$ & $\begin{array}{c}\text { Consistency } \\
\text { (cP) }\end{array}$ & $\begin{array}{c}\text { Yield Stress } \\
\text { (Pa) }\end{array}$ \\
\hline $\begin{array}{c}\text { Washed Sludge Slurry } \\
\text { (Design Basis) }^{\dagger}\end{array}$ & $13-19$ & $4-12$ & $2.5-10$ \\
\hline SRAT Receipt & 15.1 & 8.9 & 8.3 \\
\hline $\begin{array}{c}\text { SRAT Material } \\
\text { Following Caustic } \\
\text { Boiling/Concentration }\end{array}$ & 19.7 & 12.3 & 12 \\
\hline $\begin{array}{c}\text { SRAT Slurry } \\
\text { (Design Basis) }^{\dagger}\end{array}$ & $18-25$ & $5-12$ & $1.5-5$ \\
\hline SRAT Product & 25.9 & 15.2 & 21 \\
\hline
\end{tabular}

${ }^{\dagger}$ From Basic Data Report: Defense Waste Processing Facility ludge Plant; Savannah River Plant 200-S Area, DPSP-80-1033, Revision 10.

\subsection{Glass Fabrication and PCT}

Table 3-16 shows the elemental (excluding oxygen) composition of the SB6 Qualification Glass. Elements specifically requested in the TTR ${ }^{1}$ (e.g., elements grater than $0.1 \mathrm{wt} \%$ in the sludge), along with elements necessary for PCCS calculations (e.g., $\mathrm{Cu}$ and $\mathrm{Nd}$ ), are reported. Essentially all of the B, Li and $\mathrm{Si}$ and a portion of the $\mathrm{Na}$ are from the glass frit added to the SRAT product in order to prepare the glass. The frit used was Frit 418, which has a nominal composition of 76 wt $\% \mathrm{SiO}_{2}, 8$ wt $\% \mathrm{~B}_{2} \mathrm{O}_{3}, 8$ wt $\%$ $\mathrm{Li}_{2} \mathrm{O}$ and $8 \mathrm{wt} \% \mathrm{Na}_{2} \mathrm{O}$. Depending upon the element, the results in Table 3-16 represent an average of four or eight measurements resulting from the glass dissolution and analysis techniques mentioned in the experimental procedure. The dissolution and analytical technique used is noted in Table 3-16. next to each element. If one dissolution technique is listed then the result is an average of 4 replicates, but if both dissolution techniques are listed, the result for that element is an average of 8 replicates. 
SRNL-STI-2010-00353

Revision 0

Table 3-16. Average of Elemental Concentrations Measured in SB6 Qualification Glass

\begin{tabular}{|c|c|c|c|c|}
\hline Element & Wt \% & \% RSD & $\begin{array}{l}\text { Digestion } \\
\text { Method }^{\mathrm{a}}\end{array}$ & $\begin{array}{c}\text { Detection } \\
\text { Method }\end{array}$ \\
\hline $\mathrm{Ag}$ & 0.014 & 15.20 & $\mathrm{PF}$ & ICP-MS \\
\hline $\mathrm{Al}$ & 4.528 & 4.44 & $\mathrm{MA} / \mathrm{PF}$ & ICP-AES \\
\hline $\mathrm{B}$ & 1.598 & 1.39 & PF & ICP-AES \\
\hline $\mathrm{Ba}$ & 0.038 & 3.32 & $\mathrm{MA} / \mathrm{PF}$ & ICP-AES \\
\hline $\mathrm{Ca}$ & 0.275 & 2.77 & MA & ICP-AES \\
\hline $\mathrm{Cd}$ & 0.003 & 4.87 & MA & ICP-AES \\
\hline $\mathrm{Ce}$ & 0.049 & 2.60 & PF & ICP-MS \\
\hline $\mathrm{Co}$ & 0.004 & 5.28 & MA & ICP-AES \\
\hline $\mathrm{Cr}$ & 0.021 & 9.48 & $\mathrm{MA} / \mathrm{PF}$ & ICP-AES \\
\hline $\mathrm{Cu}$ & 0.025 & 9.88 & $\mathrm{MA} / \mathrm{PF}$ & ICP-AES \\
\hline $\mathrm{Fe}$ & 4.743 & 3.02 & $\mathrm{MA} / \mathrm{PF}$ & ICP-AES \\
\hline $\mathrm{Gd}$ & 0.025 & 8.08 & $\mathrm{MA} / \mathrm{PF}$ & ICP-AES \\
\hline $\mathrm{K}$ & 0.053 & 8.59 & MA & ICP-AES \\
\hline $\mathrm{La}$ & 0.025 & 10.11 & $\mathrm{MA} / \mathrm{PF}$ & ICP-AES \\
\hline $\mathrm{Li}$ & 2.450 & 3.12 & $\mathrm{MA} / \mathrm{PF}$ & ICP-AES \\
\hline $\mathrm{Mg}$ & 0.098 & 3.85 & $\mathrm{MA} / \mathrm{PF}$ & ICP-AES \\
\hline $\mathrm{Mn}$ & 1.756 & 2.30 & $\mathrm{MA} / \mathrm{PF}$ & ICP-AES \\
\hline Mo & 0.007 & 5.23 & MA & ICP-AES \\
\hline $\mathrm{Na}$ & 10.153 & 4.88 & MA & ICP-AES \\
\hline $\mathrm{Nd}$ & 0.088 & 3.77 & $\mathrm{PF}$ & ICP-MS \\
\hline $\mathrm{Ni}$ & 0.730 & 2.70 & $\mathrm{MA} / \mathrm{PF}$ & ICP-AES \\
\hline $\mathrm{P}$ & 0.052 & 4.33 & MA & ICP-AES \\
\hline $\mathrm{Pb}$ & 0.007 & 5.81 & MA & ICP-AES \\
\hline $\mathrm{S}$ & 0.087 & 13.41 & MA & ICP-AES \\
\hline $\mathrm{Sb}$ & $<0.011$ & N/A & MA & ICP-AES \\
\hline $\mathrm{Si}$ & 25.475 & 1.65 & $\mathrm{PF}$ & ICP-AES \\
\hline $\mathrm{Sn}$ & $<0.010$ & N/A & MA & ICP-AES \\
\hline $\mathrm{Sr}$ & 0.018 & 3.30 & $\mathrm{MA} / \mathrm{PF}$ & ICP-AES \\
\hline Th & 1.030 & 4.43 & PF & ICP-MS \\
\hline $\mathrm{Ti}$ & 0.012 & 6.28 & $\mathrm{MA} / \mathrm{PF}$ & ICP-AES \\
\hline $\mathrm{U}$ & 0.874 & 3.40 & PF & ICP-MS \\
\hline $\mathrm{V}$ & $<0.004$ & N/A & MA & ICP-AES \\
\hline $\mathrm{Y}$ & 0.012 & 6.97 & $\mathrm{PF}$ & ICP-MS \\
\hline $\mathrm{Zn}$ & 0.016 & 5.79 & MA & ICP-AES \\
\hline $\mathrm{Zr}$ & 0.100 & 2.91 & MA & ICP-AES \\
\hline Sum & 54.365 & & & \\
\hline
\end{tabular}

${ }^{\mathrm{a}} \mathrm{PF}=$ Peroxide Fusion dissolution method, MA = Mixed Acid dissolution method 
The measured SB6 Qualification Glass elemental concentrations reported in Table 3-16 were converted to an oxide basis and used to predict the properties of the glass based on the PCCS models and are listed in Table 3-17. All other elements listed in Table 3-16 and not found in Table 3-17 were $\leq 0.1 \mathrm{wt} \%$ oxide in the glass or were not used to complete the PCCS Measurement Acceptability Region (MAR) assessment. The predicted properties from this composition were then compared to SME acceptability criteria to evaluate whether this glass did indeed meet the DWPF processing and product quality constraints. Based on the measured composition, all of the predicted properties met the PCCS MAR criteria and a list of the predicted properties is found in Table 3-18.

Table 3-17. Measured SB6 Qualification Glass Composition on an Oxide Basis for Input into PCCS

\begin{tabular}{||c|c|c|c|c||}
\hline Oxide & Weight \% & & Oxide & Weight \% \\
\hline \hline $\mathrm{Al}_{2} \mathrm{O}_{3}$ & 8.555 & & $\mathrm{Na}_{2} \mathrm{O}$ & 13.686 \\
\hline $\mathrm{B}_{2} \mathrm{O}_{3}$ & 5.144 & & $\mathrm{Nd}_{2} \mathrm{O}_{3}$ & 0.103 \\
\hline $\mathrm{BaO}$ & 0.042 & & $\mathrm{NiO}$ & 0.929 \\
\hline $\mathrm{CaO}$ & 0.385 & & $\mathrm{P}_{2} \mathrm{O}_{5}$ & 0.120 \\
\hline $\mathrm{Ce}_{2} \mathrm{O}_{3}$ & 0.057 & & $\mathrm{PbO}^{2}$ & 0.008 \\
\hline $\mathrm{Cr}_{2} \mathrm{O}_{3}$ & 0.030 & & $\mathrm{SO}_{4}{ }^{2-}$ & 0.260 \\
\hline $\mathrm{CuO}^{2}$ & 0.031 & & $\mathrm{SiO}_{2}$ & 54.499 \\
\hline $\mathrm{Fe}_{2} \mathrm{O}_{3}$ & 6.780 & & $\mathrm{ThO}_{2}$ & 1.172 \\
\hline $\mathrm{K}_{2} \mathrm{O}$ & 0.064 & & $\mathrm{TiO}_{2}$ & 0.020 \\
\hline $\mathrm{La}_{2} \mathrm{O}_{3}$ & 0.030 & & $\mathrm{U}_{3} \mathrm{O}_{8}$ & 1.030 \\
\hline $\mathrm{Li}{ }_{2} \mathrm{O}$ & 5.275 & & $\mathrm{Y}_{2} \mathrm{O}_{3}$ & 0.015 \\
\hline $\mathrm{MgO}$ & 0.163 & & $\mathrm{ZnO}_{2}$ & 0.019 \\
\hline $\mathrm{MnO}$ & 2.268 & & $\mathrm{ZrO}_{2}$ & 0.135 \\
\hline $\mathrm{MoO}$ & 0.011 & & $\mathrm{SUM}_{3}$ & $\mathbf{1 0 0 . 8 3 0}$ \\
\hline \hline
\end{tabular}


Table 3-18. PCCS Results for SB6 Qualification Glass

\begin{tabular}{||c|c|}
\hline$\Delta \mathrm{G}_{\mathrm{p}}$ Value & -10.2055 \\
\hline $\mathrm{NL}[\mathrm{B}(\mathrm{g} / \mathrm{L})]$ & 0.8868 \\
\hline $\mathrm{NL}[\mathrm{Li}(\mathrm{g} / \mathrm{L})]$ & 0.8959 \\
\hline $\mathrm{NL}[\mathrm{Na}(\mathrm{g} / \mathrm{L})]$ & 0.8789 \\
\hline $\mathrm{T}_{\mathrm{L}}$ Prediction $\left({ }^{\circ} \mathrm{C}\right)$ & 806.4878 \\
\hline Viscosity Prediction $(\mathrm{P})^{\circ}$ & 77.0212 \\
\hline Sum of Oxides $(\%)$ & $100.5682^{\text {a }}$ \\
\hline Nepheline Constraint Value & 0.7102 \\
\hline $\mathrm{Al}_{2} \mathrm{O}_{3}($ wt $\%)$ & 8.5547 \\
\hline All PCCS MAR Criteria Met & yes \\
\hline
\end{tabular}

${ }^{\text {a }}$ Note that PCCS does not include $\mathrm{SO}_{4}$ in its sum of oxides, accounting for the difference between the sum of oxides in this table and the sum in Table 6.

For the SB6 Qualification Glass, the waste loading was calculated based on $\mathrm{Li}_{2} \mathrm{O}$ content and sum of oxides from the chemical analysis (from Table 3-17). The targeted $\mathrm{Li}_{2} \mathrm{O}$ content of Frit 418 was also used $(8.0 \mathrm{wt} \%)$. Using these results yields a waste loading of $34.4 \mathrm{wt} \%$, which is nearly the same as the targeted $35 \mathrm{wt} \% \mathrm{WL}$.

Quadruplicate samples of the SB6 Qualification Glass were subjected to the PCT along with triplicate blanks, triplicate samples of the ARM and the EA reference glass as prescribed by the ASTM procedure. The results for the reference glasses and the blanks indicated that the test was acceptable. The water loss during the course of the test was very minimal and well within the acceptable amount of water loss as prescribed by the ASTM procedure. The blanks, and leachates from the ARM and EA references all had elemental and normalized releases within the accepted standard values. Results for the averaged normalized releases, based on $\mathrm{B}, \mathrm{Na}, \mathrm{Li}, \mathrm{Si}, \mathrm{Al}, \mathrm{Fe}$ and $\mathrm{U}$ (grams of normalized element per liter of PCT leachate) are given in Table 3-19. The normalized releases for the SB6 Qualification Glass based on B, Na, and Li are more than an order of magnitude less than those for the EA glass. These releases are also predictable by the current durability models of the DWPF PCCS. A representation of predictability for ARM, EA and the SB6 Qualification Glass are in the plots for log normalized B, Li, Na and Si release as a function of del $G_{p}$ as can be found Figure 3-7.

Table 3-19. PCT Results for ARM, EA and the SB6 Qualification Glass

\begin{tabular}{|c|c|c|c|c|c|c|c|}
\hline Glass ID & $\begin{array}{c}\text { NL (B) } \\
\text { g/L }\end{array}$ & $\begin{array}{c}\text { NL (Na) } \\
\text { g/L }\end{array}$ & $\begin{array}{c}\text { NL (Li) } \\
\text { g/L }\end{array}$ & $\begin{array}{c}\text { NL (Si) } \\
\text { g/L }\end{array}$ & $\begin{array}{c}\text { NL (Al) } \\
\text { g/L }\end{array}$ & $\begin{array}{c}\text { NL (Fe) } \\
\text { g/L }\end{array}$ & $\begin{array}{c}\text { NL (U) } \\
\text { g/L }\end{array}$ \\
\hline $\mathrm{ARM}^{\mathrm{a}}$ & 0.46 & 0.50 & 0.56 & 0.27 & 0.19 & N/A & N/A \\
\hline $\mathrm{EA}^{\mathrm{a}}$ & 17.42 & 13.65 & 9.91 & 4.01 & $<0.22$ & $<0.02$ & N/A \\
\hline SB6-QUAL $^{b}$ & 0.63 & 0.90 & 0.81 & 0.46 & 0.51 & 0.27 & 0.57 \\
\hline
\end{tabular}




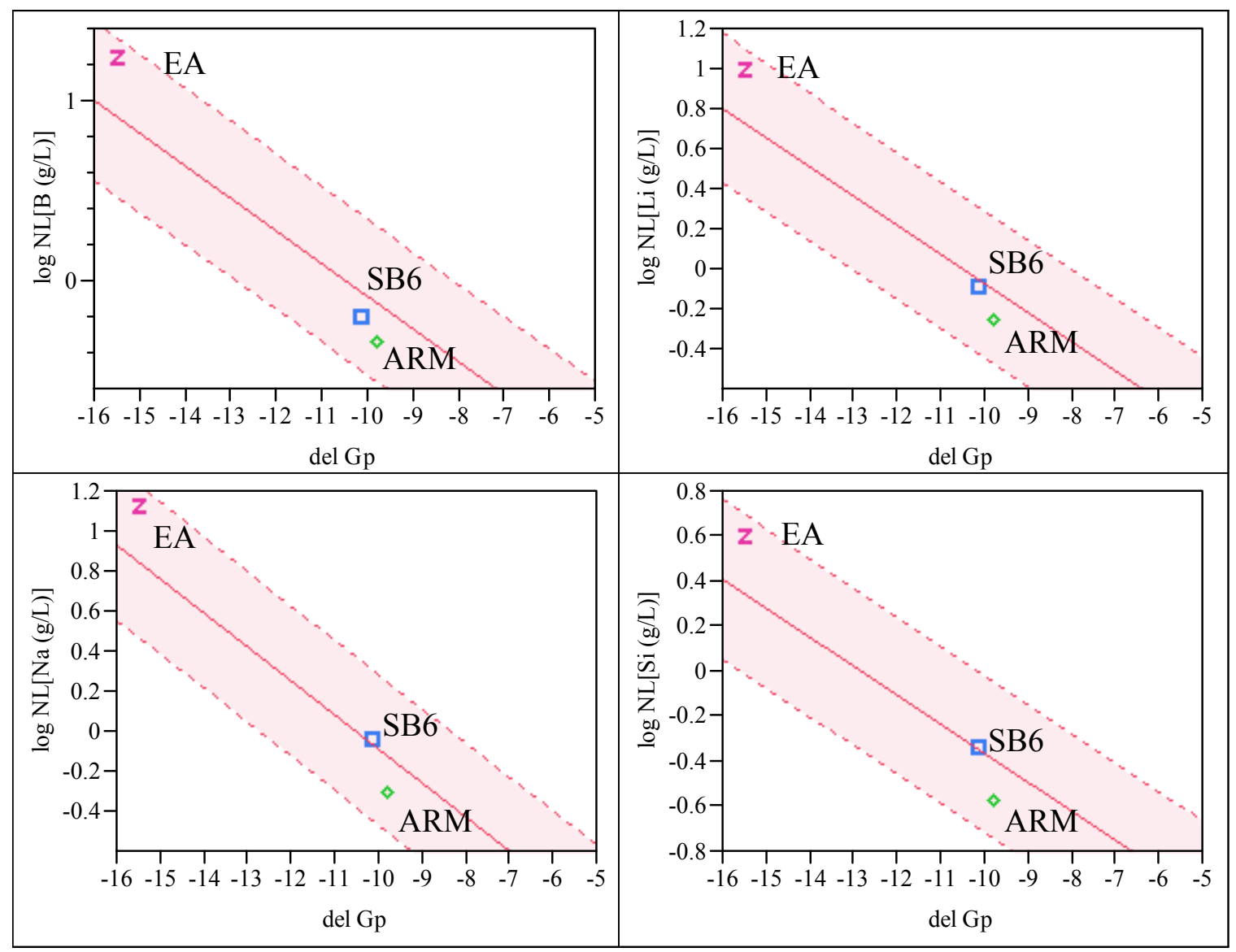

Figure 3-7. Fit of log Normalized Release of B, Li, Na and Si (g/L) vs. del G for the measured releases of ARM, EA and the SB6 Qualification glasses.

Density of the SB6 Qualification Glass was also measured using pycnometry. After measuring the glass with a calibrated graduated cylinder three times (the pycnometer utilized for these measurements), the average density was calculated to be $2.40 \mathrm{~g} / \mathrm{cm}^{3}$. This density is in the correct range for an alumino borosilicate glass.

\subsection{Conclusions}

The following conclusions are drawn from this demonstration

- Settling improved slightly as the sludge was washed.

- Thorium was detected in significant quantities $(>0.1 \mathrm{wt} \%$ of total solids in the sludge). In past sludge batches, thorium has been determined by ICP-MS, seen in small quantities, and reported with the radionuclides. As a result of the high thorium, SRNL-AD has added thorium to their suite of ICP-AES elements.

- The acid stoichiometry for SRAT processing of $115 \%$, or $1.3 \mathrm{~mol}$ acid per liter of SRAT receipt, was adequate to accomplish some of the goals of SRAT processing: 
SRNL-STI-2010-00353

Revision 0

nitrite was destroyed to below $1,000 \mathrm{mg} / \mathrm{kg}(1,000 \mathrm{mg} / \mathrm{kg}$ nitrite was the method detection limit for this sample), and mercury was removed to below the DWPF target of $0.6 \mathrm{wt} \%$ of total solids (SRAT product was $0.59 \mathrm{wt} \%$ ) with $750 \mathrm{~g}$ of steam per $\mathrm{g}$ of mercury. However, rheological properties did not improve and were above the design basis.

- Hydrogen generation rates did not exceed DWPF limits during the SRAT and SME cycles. However, the SRAT approached the limit.

Peak DWPF Scale Generation Rate $(\mathrm{lb} / \mathrm{h})$ DWPF Limit $(\mathrm{lb} / \mathrm{h})$

$\begin{array}{cc}\text { SRAT Cycle } & \text { SME Cycle } \\ 0.55 & 0.05 \\ 0.65 & 0.223\end{array}$

- The glass fabricated with the Tank 51 SB6 SME product and Frit 418 was acceptable with respect to chemical durability as measured by the PCT. For example, the SB6 glass had a normalized boron release of $0.63 \mathrm{~g} / \mathrm{L}$, while the EA glass had a normalized release of $17.42 \mathrm{~g} / \mathrm{L}$. The PCT response was also predictable by the current durability models of the DWPF PCCS.

\subsection{Recommendations and Path Forward}

- In this demonstration, at the request of DWPF, SRNL caustic boiled the SRAT contents prior to acid addition to remove water (to increase solids concentration). During the nearly five hours of caustic boiling, foaming was constant; $700 \mathrm{ppm}$ of antifoam was required to control foaming. SRNL recommends that DWPF not caustic boil/concentrate SRAT receipt prior to acid addition until further studies can be performed to provide a better foaming control strategy or a new antifoam is developed for caustic boiling.

- Based on this set of runs and a recently completed demonstration with the SB6 Waste Acceptance Product Specifications (WAPS) sample, it is recommended that DWPF not add formic acid at the design addition rate of two gallons per minute for this sludge batch. A longer acid addition time appears to be helpful in allowing slower reaction of formic acid with the sludge and possibly decreases the chance of a foam over during acid addition.

- Processing time (post acid addition concentration plus reflux) can be targeted from the mercury content. Mercury was stripped at the predicted $750 \mathrm{~g}$ steam per $\mathrm{g} \mathrm{Hg}$.

- As stated above, SRNL has completed CPC processing with a Tank 40 sample. SRNL did not concentrate prior to acid addition, and formic acid was added at a scaled one gallon per minute. A comparison of this run with the SB6 qualification run will be documented. 
SRNL-STI-2010-00353

Revision 0

\subsection{References}

1. $\quad$ Bricker, J. M. Technical Task Request: Sludge Batch 6 Shielded Cells Testing; HLW-DWPF-TTR-2009-0014, Rev. 2; Savannah River Site: Aiken, SC, 2010.

2. Koopman, D. C. Recommendations for SB6 Qualification Processing in the Shielded Cells; SRNL-L3100-2010-00028, Rev. 0; Savannah River National Laboratory: Aiken, SC, 2010.

3. Bannochie, C. J.; Pareizs, J. M. Qualification of DWPF Sludge Batch 6 and Characterization of Tank 4 Samples in the SRNL Shielded Cells: Task Technical \& Quality Assurance Plan; SRNL-RP-2009-00473, Rev. 2; Savannah River National Laboratory: Aiken, SC, 2009.

4. Bannochie, C. J.; Pareizs, J. M. Qualification of DWPF Sludge Batch 6 and Characterization of Tank 4 Samples in the SRNL Shielded Cells: Analytical Study Plan; SRNL-RP-2009-00474, Rev. 1; Savannah River National Laboratory: Aiken, SC, 2010.

5. Coleman, C. J. Aqua Regia Dissolution of Sludge for Elemental Analysis; Manual L16.1, Procedure ADS-2226, Rev. 9; Savannah River National Laboratory: Aiken, SC, 2009.

6. Coleman, C. J. Coleman, C. J. Alkali Fusion Dissolutions of Sludge and Glass for Elemental and Anion Analysis; Manual L16.1, ADS-2502, Rev. 6; Savannah River National Laboratory: Aiken, SC, 2008.

7. Smith, G. L. Characterization of Analytical Reference Glass - 1 (ARG-1); PNL8992; Pacific Northwest National Laboratory: Richland, WA, 1993.

8. Darby, R., Chemical Engineering Fluid Mechanics, 2nd edition. Marcel Dekker: 2001.

9. Gillam, J. M. SB6_111009_test case_new settling.xls, Worksheet SB6: Tank Farm Washing Spreadsheet, Savannah River Remediation: Aiken, SC, 2009.

10. E\&CPT Research Programs Section Procedure Manual; Manual L29; Savannah River National Lab: Aiken, SC, 2010.

11. Pickenheim, B. R. SRAT Assembly for SB6 Shielded Cells Testing: SC-9; SRNLL3100-2010-00031; Savannah River national Laboratory: Aiken, SC, 2010.

12. Sludge Batch 6 III; SRNL-NB-2009-00170; Savannah River National Laboratory: Aiken, SC, 2010.

13. Sludge Batch 6 IV; SRNL-NB-2009-00171; Savannah River National Laboratory: Aiken, SC, 2010. 
SRNL-STI-2010-00353

Revision 0

14. Lambert, D. P. Acid Calculation Spreadsheet for DWPF Simulations, Revision 1; Inter-Office Memorandum SRNL-PSE-2006-00173; Savannah River National Laboratory: Aiken, SC, 2006.

15. Jantzen, C. M.; Stone, M. E. Role of Manganese Reduction/Oxidation (REDOX) on Foaming and Melt Rate in High Level Waste (HLW) Melters (U); WSRC-STI2006-00066; Savannah River National Laboratory: Aiken, SC, 2007.

16. Standard Test Methods for Determining chemical durability of nuclear, hazardous, and mixed waste glasses and Multiphase glass ceramics: the product consistency test (PCT); American Society for Testing and Materials (ASTM): West Conshohocken, PA, 2002.

17. Waste Acceptance Product Specification for Vitrified High-Level-Waste Forms; Office of Environmental Management USDOE Document: 1996.

18. Jantzen, C. M.; Bibler, N. E.; Beam, D. C.; Crawford, C. L.; Pickett, M. A. Characterization of the Defense Waste Processing Facility (DWPF) environmental Assessment (EA) Glass Standard Reference Material; WSRC-TR92-346; Savannah River Site: Aiken, SC, 1994. 
SRNL-STI-2010-00353

Revision 0

Appendix A. Excerpt From November 10, 2009 Tank Farm Washing Spreadsheet 


\begin{tabular}{|c|c|c|c|c|c|c|c|c|c|c|c|c|}
\hline & A & $\mathrm{Bl}$ & BJ & BK & $\overline{B L}$ & BM & $\mathrm{BN}$ & $\mathrm{BO}$ & $\mathrm{BP}$ & $B Q$ & $\mathrm{BR}$ & $\overline{B S}$ \\
\hline 1 & & $10 / 8 / 2009$ & $11 / 07 / 09$ & & & $11 / 12 / 09$ & & & $11 / 19 / 09$ & $12 / 12 / 09$ & $12 / 14 / 09$ & \\
\hline 2 & Tank 51 & $\begin{array}{c}\text { Tank 51 } \\
\text { after 4-51-1 }\end{array}$ & $\begin{array}{l}\text { Decant A to } \\
\text { Tank } 4\end{array}$ & $\begin{array}{l}\text { Tank } 51 \text { after } \\
\text { Decant }\end{array}$ & Add Caustic & Add IW & $\begin{array}{l}\text { Pu Adds for } \\
\text { SB6 }\end{array}$ & $\begin{array}{l}\text { Flush Volume at } \\
\text { End of Pu } \\
\text { Receipt for this } \\
\text { Decant }\end{array}$ & $\begin{array}{l}\text { Tank } 51 \text { after } \\
\text { Additions }\end{array}$ & $\begin{array}{l}\text { Decant B to } \\
2 \mathrm{~F}\end{array}$ & $\begin{array}{l}\text { Tank } 51 \text { after } \\
\text { Decant B }\end{array}$ & $\begin{array}{l}\text { Continuation of } \\
\text { Pu Addsfor SBG }\end{array}$ \\
\hline 3 & Initial tank Level (in) & 145.20 & & 123.60 & & & & & 187.00 & & 135.10 & \\
\hline 4 & liquid volume (gal) & 488552 & 75816 & 412736 & 29000 & 184609 & 5902 & 1500 & 633748 & 182169 & 451579 & 1967 \\
\hline 5 & sludge volume (gal) & 21100 & & 21100 & & & 23 & & 22622 & & 22622 & 8 \\
\hline 6 & settled sludge level (in) & 119.10 & & & & & & & 129.10 & & & \\
\hline 7 & kg insol. solids & 159724 & & 159724 & & & 205 & & 159928 & & 159928 & 68 \\
\hline 8 & wt\% insol solids & 6.00 & & 6.99 & & & & & 5.03 & & 6.91 & \\
\hline 9 & decant level & 123.10 & & & & & & & 133.10 & & & \\
\hline 10 & NO2/NO3 & & & & & & & & & & & \\
\hline 11 & additional nitrite solution & & mole $\mathrm{Na}=$ & & & & & & 6.138 & mole $\mathrm{Na}=$ & & \\
\hline 12 & Jadditional volume & 30727 & $2.45 E+06$ & & & 0 & & & & $4.47 E+06$ & & \\
\hline 13 & $S p G$ & 1.3600 & 1.360 & 1.360 & 1.530 & 1.000 & 1.140 & 1.033 & 1.260 & 1.260 & 1.2601 & 1.140 \\
\hline 14 & $\mathrm{Na}$ & 8.550 & 8.550 & 8.550 & 19.125 & 0.021 & 3.035 & 1.200 & 6.481 & 6.481 & 6.4807 & 3.035 \\
\hline 15 & NO2 & 1.2700 & 1.270 & 1.270 & 0.000 & 0.011 & 0.002 & & 0.830 & 0.830 & 0.8303 & 0.002 \\
\hline 16 & NO3 & 1.2700 & 1.270 & 1.270 & 0.000 & 0.000 & 1.677 & & 0.847 & 0.847 & 0.8467 & 1.677 \\
\hline 17 & $\mathrm{OH}$ & 3.5300 & 3.530 & 3.530 & 19.125 & 0.010 & 1.200 & 1.200 & 3.191 & 3.191 & 3.1910 & 1.200 \\
\hline 18 & & 0.0180 & 0.018 & 0.018 & 0.430 & 0.000 & 0.003 & & 0.031 & 0.031 & 0.0314 & 0.003 \\
\hline 19 & $\mathrm{SO} 4$ & 0.1840 & 0.184 & 0.184 & 0.000 & 0.000 & 0.001 & & 0.120 & 0.120 & 0.1198 & 0.001 \\
\hline 20 & & 0.0042 & 0.004 & 0.004 & 0.000 & 0.000 & 0.005 & & 0.003 & 0.003 & 0.0028 & 0.005 \\
\hline 21 & $\mathrm{CO}_{2}-2$ & 0.5030 & 0.503 & 0.503 & 0.000 & 0.000 & 0.0002 & & 0.328 & 0.328 & 0.3276 & 0.0002 \\
\hline 22 & $\mathrm{AO} 2$ & 0.7980 & 0.798 & 0.798 & 0.000 & 0.000 & 0.017 & & 0.520 & 0.520 & 0.5199 & 0.017 \\
\hline 23 & $\mathrm{C} 2 \mathrm{O} 4-2$ & 0.50028 & 0.003 & 0.003 & 0.000 & 0.000 & 0.000 & & 0.002 & 0.002 & 0.0018 & 0.000 \\
\hline$\frac{25}{24}$ & $\mathrm{PO}_{4-3}$ & 0.0065 & 0.007 & 0.007 & 0.000 & 0.000 & 0.001 & & 0.004 & 0.004 & 0.0043 & 0.001 \\
\hline 25 & & 0.0188 & 0.019 & 0.019 & 0.000 & 0.000 & 0.005 & & 0.012 & 0.012 & 0.0123 & 0.005 \\
\hline 26 & Soluble $\mathrm{Na} 2 \mathrm{C} 2 \mathrm{O} 4, \mathrm{M}$ & & & & & & & & & & & \\
\hline 27 & Insol Na2C204, kg & 0 & & & & & & & & & & \\
\hline 28 & Heat Load & & & & & & & & & & & \\
\hline 29 & Sludge b/g & 145212 & 0 & 145212 & 0.0 & 0.0 & 0 & 0 & 145212 & 0 & 145212 & 0 \\
\hline 30 & Sludge a & 14178 & 0 & 14178 & 0.0 & 0.0 & 168 & 0 & 14346 & 0 & 14346 & 56 \\
\hline 31 & supernate b/g & $\begin{array}{l}14170 \\
11239\end{array}$ & 1744 & 94170 & 0.0 & 0.0 & 100 & 0 & $\frac{14540}{9495}$ & & $\frac{14540}{6765}$ & 0 \\
\hline 32 & supernate a & 347 & 54 & $\begin{array}{c}\frac{9450}{293} \\
\end{array}$ & 0.0 & 0.0 & 0 & 0 & 293 & 84 & $\frac{1000}{209}$ & 0 \\
\hline 33 & Temperature Basis. C & 40 & & & & & & & 40 & 0.7 & & \\
\hline 34 & C-LFL (corrected) & 0.03734 & & & & & & & 0.03734 & & & \\
\hline 35 & NOeff (M) & 1.8505 & & & & & & & 1.2337 & & & \\
\hline 36 & $\mathrm{Rb} / \mathrm{g}$ & 5.89 & & & & & & & 8.68 & & & \\
\hline 37 & Ra & 35.01 & & & & & & & 45.35 & & & \\
\hline 38 & $\mathrm{H} 2 \mathrm{~b} / \mathrm{g}$ & 0.92 & & & & & & & 1.34 & & & \\
\hline 39 & $\mathrm{H} 2$ alpha & 0.51 & & & & & & & 0.66 & & & \\
\hline 40 & Total H2 (cut/hr) & 1.43 & & & & & & & 2.01 & & & \\
\hline 44 & $\mathrm{Q}(\mathrm{H} 2)$, Temp Corrected & 1.64 & & & & & & & 2.30 & & & \\
\hline 42 & $\mathrm{~W}, \mathrm{ft}$ (for seismic) & 115375 & & & & & & & 95774 & & & \\
\hline 44 & 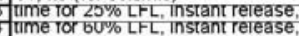 & & & & & & & & & & & \\
\hline 45 & tyo & 0.007835 & & & & & & & 0.007835 & & & \\
\hline 46 & HLLCP & 225.0 & & & & & & & 197.00 & & & \\
\hline $\begin{array}{lll}400 \\
47\end{array}$ & Flammability Level & 231.274 & & & & & & & 203.274 & & & \\
\hline 48 & W. A3 (for vent loss) & 75,012 & & & & & & & 88,142 & & & \\
\hline 49 & $Q$ (for vent loss) & 15.427 & & & & & & & 18.127 & & & \\
\hline 50 & Days to LFL (vent loss) & 74.55 & & & & & & & 59.43 & & & \\
\hline 51 & Flammability Classification & slow & & & & & & & Slow & & & \\
\hline 52 & Q. seismic & 23.73 & & & & & & & 19.70 & & & \\
\hline$\frac{53}{54}$ & Seismic Q-time, days & 83.50 & & & & & & & 46.57 & & & \\
\hline \begin{tabular}{|c|}
54 \\
59 \\
\end{tabular} & $\begin{array}{l}\text { Mass TS, kg } \\
\text { wt\% TS }\end{array}$ & 38.00 & & & & & & & & & & \\
\hline
\end{tabular}




\begin{tabular}{|c|c|c|c|c|c|c|c|c|c|c|c|c|}
\hline & A & $\mathrm{BT}$ & $\mathrm{BU}$ & BV & BW & $\mathrm{BX}$ & BY & $\mathrm{BZ}$ & CA & $\mathrm{CB}$ & $\mathrm{CC}$ & $C D$ \\
\hline 1 & & & $12 / 21 / 09$ & $01 / 06 / 10$ & $01 / 29 / 10$ & & $01 / 31 / 10$ & $02 / 02 / 10$ & $02 / 22 / 10$ & & $02 / 24 / 10$ & $02 / 26 / 10$ \\
\hline 2 & Tank 51 & \begin{tabular}{|c|} 
Additional \\
Dilution to \\
Continuation of \\
Pu Adds \\
\end{tabular} & Add IW & $\begin{array}{l}\text { Tank } 51 \text { after } \\
\text { Pu Receipt \& } \\
\text { IWAdd }\end{array}$ & $\begin{array}{c}\text { Decant } C \text { to } \\
\text { Tank } 4\end{array}$ & $\begin{array}{c}\text { Tank } 51 \text { after } \\
\text { Decant }\end{array}$ & Add IW & $\begin{array}{l}\text { Tank } 51 \\
\text { after IW } \\
\text { Add }\end{array}$ & Decant D to $3 \mathrm{H}$ & $\begin{array}{c}\text { Tank } 51 \text { after } \\
\text { Decant }\end{array}$ & Add IW & $\begin{array}{l}\text { Tank } 51 \\
\text { after IW } \\
\text { Add }\end{array}$ \\
\hline 3 & Initial tank Level (in) & & & 187.00 & & 135.10 & fod of & 178.84 & & 136.10 & & 183.24 \\
\hline 4 & liquid volume (gal) & 3500 & 176694 & 633740 & 182169 & 451571 & 153510 & 605081 & 150000 & 455081 & 170461 & 625542 \\
\hline 5 & $\begin{array}{l}\text { sludge volume (gal) } \\
\text { settled sludge level (in) }\end{array}$ & & & 22630 & & 22630 & & 22630 & & 22630 & & 17613 \\
\hline \begin{tabular}{l|l}
6 & 1 \\
7 &
\end{tabular} & \begin{tabular}{|l} 
settled sludge level (in) \\
$\mathrm{kg}$ insol. solids
\end{tabular} & & & 129.10 & & & & 130.10 & & & & 134.50 \\
\hline $7+1$ & \begin{tabular}{|l|l|} 
kg insol. solids \\
wt\% insol solids
\end{tabular} & & & 159997 & & 159997 & & 159997 & & 159997 & & 159997 \\
\hline 8 & \begin{tabular}{|l} 
wt\% insol solids \\
decant level
\end{tabular} & & & & & 7.31 & & & 252720 & 7.54 & & \\
\hline \begin{tabular}{l|l}
9 \\
\end{tabular} & \begin{tabular}{|l|} 
decant level \\
$\mathrm{NO} 2 \mathrm{NO}^{\mathrm{NO}}$ \\
\end{tabular} & & & 133.10 & & & & 134.10 & & & & 138.50 \\
\hline 10 & \begin{tabular}{|l|}
$\mathrm{NO} 2 / \mathrm{NO}^{\prime} 3$ \\
additional nitrite solution
\end{tabular} & & & & & & & & & & & 0.99 \\
\hline 11 & \begin{tabular}{|l|} 
additional nitrite solution \\
additional volume
\end{tabular} & & 0 & & mole $\mathrm{Na}=$ & & 0 & & mole $\mathrm{Na}=$ & & 0 & \\
\hline 12 & $\begin{array}{l}\text { additional volume } \\
\text { SpG }\end{array}$ & & 176694 & & $3.20 \mathrm{E}+06$ & & 153510 & & $1.97 E+06$ & & 170461 & \\
\hline 13 & $\begin{array}{l}\mathrm{SpG} \\
\mathrm{Na}\end{array}$ & 1.082 & 1.000 & 1.186 & 1.186 & 1.186 & 1.000 & 1.139 & 1.139 & 1.139 & 1.000 & 1.101 \\
\hline 14 & $\begin{array}{l}\mathrm{Na} \\
\mathrm{NO} 2\end{array}$ & 2.000 & 0.021 & 4.644 & 4.644 & 4.644 & 0.021 & 3.471 & 3.471 & 3.471 & 0.021 & 2.531 \\
\hline 15 & $\begin{array}{l}\mathrm{NO} 2 \\
\mathrm{NO3}\end{array}$ & & 0.011 & 0.595 & 0.595 & 0.595 & 0.011 & 0.447 & 0.447 & 0.447 & 0.011 & 0.3279 \\
\hline 16 & $\mathrm{NO} 3$ & 0.800 & 0.000 & 0.613 & 0.613 & 0.613 & 0.000 & 0.457 & 0.457 & 0.457 & 0.000 & 0.3328 \\
\hline 17 & $\mathrm{OH}$ & & 0.010 & 2.280 & 2.280 & 2.280 & 0.010 & 1.704 & 1.704 & 1.704 & 0.010 & 1.2426 \\
\hline 18 & $\begin{array}{l}\mathrm{Cl} \\
\mathrm{SO}_{4}\end{array}$ & 1.200 & 0.000 & 0.029 & 0.029 & 0.029 & 0.000 & 0.022 & 0.022 & 0.022 & 0.000 & 0.0157 \\
\hline 19 & $\mathrm{~F}_{\mathrm{F}}$ & & 0.000 & 0.085 & 0.085 & 0.085 & 0.000 & 0.064 & 0.064 & 0.064 & 0.000 & 0.0464 \\
\hline 20 & & & 0.000 & 0.002 & 0.002 & 0.002 & 0.000 & 0.001 & 0.001 & 0.001 & 0.000 & 0.0011 \\
\hline 21 & $\begin{array}{l}\mathrm{CO} 3-2 \\
\mathrm{AO} 2\end{array}$ & & 0.000 & 0.233 & 0.233 & 0.233 & 0.000 & 0.174 & 0.174 & 0.174 & 0.000 & 0.1267 \\
\hline 22 & $\begin{array}{l}\mathrm{AO} 2 \\
\mathrm{C} 2 \mathrm{O} 4-2\end{array}$ & & 0.000 & 0.370 & 0.370 & 0.370 & 0.000 & 0.276 & 0.276 & 0.276 & 0.000 & 0.2012 \\
\hline 23 & $\begin{array}{l}\mathrm{C} 2 \mathrm{O} 4-2 \\
\mathrm{PO} 4-3\end{array}$ & & 0.000 & 0.001 & 0.001 & 0.001 & 0.000 & 0.001 & 0.001 & 0.001 & 0.000 & 0.00071 \\
\hline 24 & PO4-3 & & 0.000 & 0.003 & 0.003 & 0.003 & 0.000 & 0.002 & 0.002 & 0.002 & 0.000 & 0.0017 \\
\hline 25 & & & 0.000 & 0.009 & 0.009 & 0.009 & 0.000 & 0.007 & 0.007 & 0.007 & 0.000 & 0.0048 \\
\hline 26 & $\begin{array}{l}\text { Soluble } \mathrm{Na} 2 \mathrm{C} 2 \mathrm{O} 4, \mathrm{M} \\
\text { Insol } \mathrm{Na} 2 \mathrm{C} 204, \mathrm{~kg}\end{array}$ & & & & & & & & & & & \\
\hline$\frac{27}{28}$ & \begin{tabular}{|l} 
Insol Na2C204, kg \\
Heat Load
\end{tabular} & & & & & & & & & & & \\
\hline 29 & Sludge b/g & 0 & 0.0 & 145212 & 0 & 145212 & 00 & 145212 & 0 & 145212 & 00 & 145212 \\
\hline 30 & Sludge a & 0 & 0.0 & 14402 & 0 & 14402 & 0.0 & 14402 & 0 & 14402 & 0.0 & 14402 \\
\hline 31 & supernate $\mathrm{b} / \mathrm{g}$ & 0 & 0.0 & 6765 & 1945 & 4821 & 0.0 & 4821 & 1195 & 3626 & 0.0 & 3626 \\
\hline 32 & supernate a & 0 & 0.0 & 209 & 60 & 149 & 0.0 & 149 & 37 & 112 & 0.0 & 112 \\
\hline 33 & Temperature Basis. C & & & 40 & & & & 40 & & & & 40 \\
\hline 34 & C-LFL (corrected) & & & 0.03734 & & & & 0.03734 & & & & 0.03734 \\
\hline 35 & Noeff $(M)$ & & & 0.8900 & & & & 0.6649 & & & & 0.4854 \\
\hline 36 & $\mathrm{Rb} / \mathrm{g}$ & & & 11.14 & & & & 13.41 & & & & 15.85 \\
\hline 37 & $\mathrm{Ra}$ & & & 53. & & & & 60.35 & & & & 67.33 \\
\hline 38 & $\mathrm{H} 2 \mathrm{~b} / \mathrm{g}$ & & & 1.69 & & & & 2.01 & & & & 2.36 \\
\hline 39 & H2 alpha & & & 0.78 & & & & 0.88 & & & & 0.98 \\
\hline 40 & Total H2 (cutthr) & & & 2.47 & & & & 2.89 & & & & 3.34 \\
\hline 41 & $Q(H 2)$, Temp Corrected & & & 2.84 & & & & 3.31 & & & & 3.83 \\
\hline 42 & $\mathrm{~W}$, ft 3 (for seismic) & & & 95774 & & & & 99602 & & & & 97539 \\
\hline 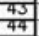 & 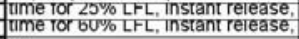 & & & & & & & & & & & \\
\hline 45 & & & & 0.007835 & & & & 0.007835 & & & & 0.007835 \\
\hline 46 & HLLCP & & & 197.00 & & & & 197.00 & & & & 197.00 \\
\hline 47 & Flammability Level & & & 203.274 & & & & 203.274 & & & & 203.274 \\
\hline 48 & W. $\mathrm{fl}$ (for vent loss) & & & 88,142 & & & & 88,142 & & & & 88,142 \\
\hline 49 & $Q$ (for vent loss) & & & 18.127 & & & & 18.127 & & & & 18.127 \\
\hline 50 & Days to LFL (vent loss) & & & 46.11 & & & & 38.47 & & & & 32.64 \\
\hline 51 & Flammability Classification & & & slow & & & & slow & & & & slow \\
\hline 52 & Q. seismic & & & 19.70 & & & & 20.48 & & & & 20.06 \\
\hline$\frac{53}{54}$ & Seismic Q-time, days & & & 36.48 & & & & 31.73 & & & & 25.86 \\
\hline$\frac{54}{59}$ & \begin{tabular}{|l} 
Mass TS, kg \\
wt\% TS
\end{tabular} & & & & & & & & & & & \\
\hline
\end{tabular}




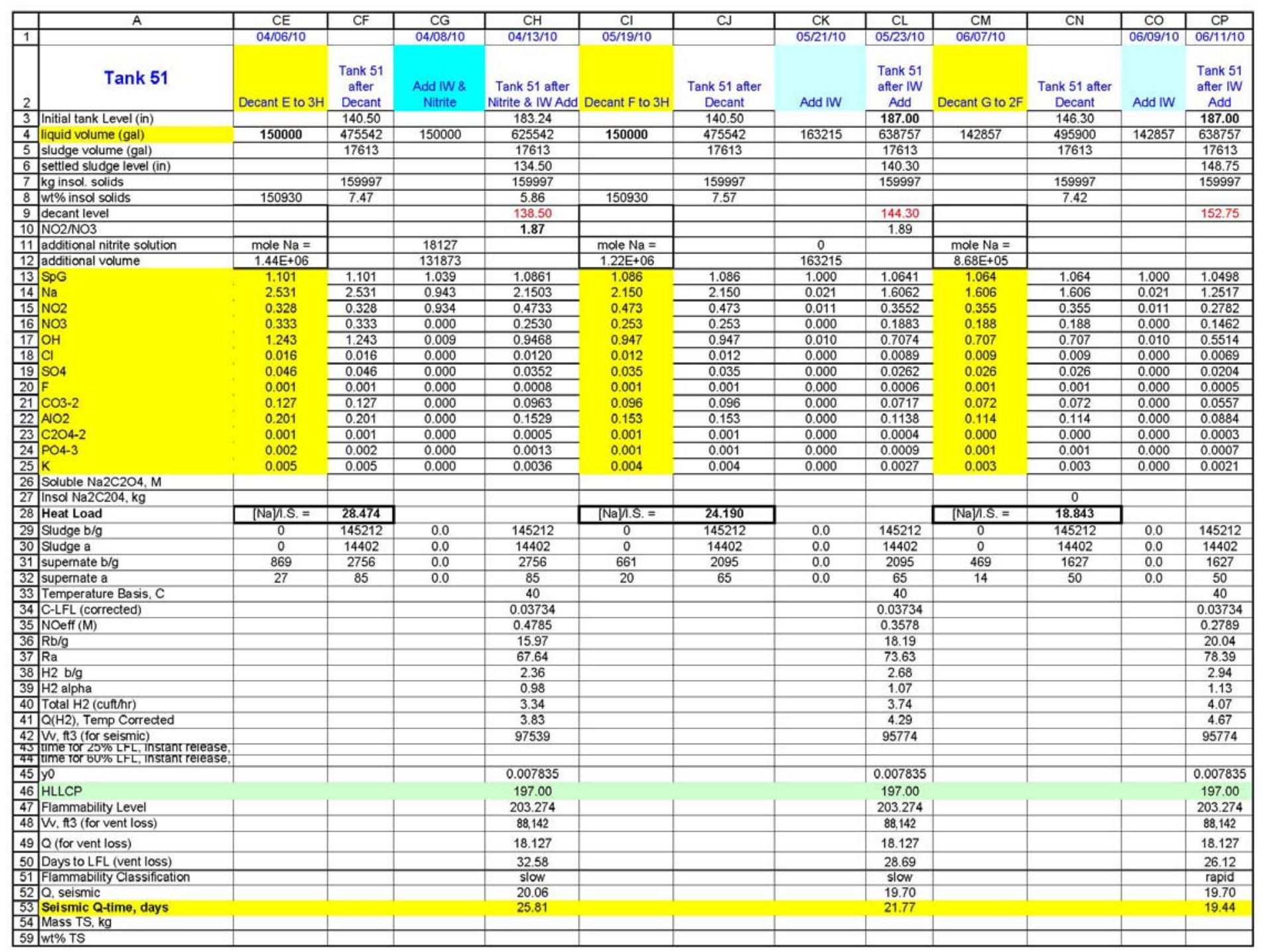




\begin{tabular}{|c|c|c|c|c|c|c|c|c|c|c|c|c|c|}
\hline 1 & A & $\frac{C Q}{06 / 24 / 10}$ & $\mathrm{CR}$ & CS & CT & $\mathrm{CU}$ & $\mathrm{CV}$ & $\mathrm{CW}$ & \begin{tabular}{|c|} 
CX \\
071210
\end{tabular} & $\mathrm{CY}$ & $\mathrm{CZ}$ & DA & $\mathrm{DB}$ \\
\hline & & & & & $06 / 27 / 10$ & & & & $07 / 12 / 10$ & & & & \\
\hline 2 & Tank 51 & Decant $\mathrm{H}$ to $3 \mathrm{H}$ & $\begin{array}{c}\text { Tank } 51 \text { after } \\
\text { Decant } \\
15475\end{array}$ & Add IW & $\begin{array}{l}\text { Tank } 51 \\
\text { after IW } \\
\text { Add }\end{array}$ & Decant I to $2 F$ & $\begin{array}{c}\text { Tank } 51 \text { after } \\
\text { Decant }\end{array}$ & Add IW & $\begin{array}{l}\text { Tank } 51 \\
\text { after IW } \\
\text { Add }\end{array}$ & Decant $\mathrm{J}$ to $3 \mathrm{H}$ & $\begin{array}{c}\text { Tank } 51 \text { after } \\
\text { Decant }\end{array}$ & Add IW & $\begin{array}{c}\text { Tank } 51 \\
\text { after IW } \\
\text { Add }\end{array}$ \\
\hline \begin{tabular}{|l|}
3 \\
\end{tabular} & $\begin{array}{l}\text { Initial tank Level (in) } \\
\text { liquid volume (gal) }\end{array}$ & 113198 & \begin{tabular}{|c|}
154.75 \\
525559 \\
\end{tabular} & & & & & & & & & & \\
\hline \begin{tabular}{|l|}
4 \\
5 \\
\end{tabular} & $\begin{array}{l}\text { liquid volume (gal) } \\
\text { sludge volume (gal) }\end{array}$ & & $\begin{array}{l}525559 \\
17613 \\
\end{array}$ & 113198 & $\frac{638757}{17613}$ & 98280 & 540477 & 98280 & $\frac{638757}{17613}$ & 98280 & 540477 & 98280 & $\begin{array}{ll}638757 \\
17613\end{array}$ \\
\hline \begin{tabular}{|c|}
6 \\
\end{tabular} & settled sludge level (in) & & & & 153.00 & & & & 153.00 & & & & 15725 \\
\hline \begin{tabular}{|l|l}
7 \\
\end{tabular} & kg insol. solids & & 159997 & & 159997 & & 159997 & & 159997 & & 159997 & & 159997 \\
\hline \begin{tabular}{|l|}
8 \\
\end{tabular} & wt\% insol solids & 126360 & 7.12 & & & 224640 & 6.99 & & & 105300 & 7.03 & & \\
\hline \begin{tabular}{|l|l|}
9 & \\
\end{tabular} & decant level & & & & 157.00 & & & & 157.00 & & & & 161.25 \\
\hline \begin{tabular}{|l|}
10 \\
\end{tabular} & NO2/NO3 & & & & 1.92 & & & & 1.94 & & & & 1.96 \\
\hline 11 & additional nitrite solution & mole $\mathrm{Na}=$ & & & & mole $\mathrm{Na}=$ & & & & mole $\mathrm{Na}=$ & & & \\
\hline 12 & additional volume & $5.36 \mathrm{E}+05$ & & & & $3.84 E+05$ & & & & $3.27 E+05$ & & & \\
\hline 13 & SpG & 1.050 & 1.050 & 1.000 & 1.0409 & 1.041 & 1.041 & 1.000 & 1.035 & 1.035 & 1.035 & 1.000 & 1.029 \\
\hline 14 & & 1.252 & 1.252 & 0.021 & 1.0336 & 1.034 & 1.034 & 0.021 & 0.878 & 0.878 & 0.878 & 0.021 & 0.746 \\
\hline 15 & NO2 & 0.278 & 0.278 & 0.011 & 0.2308 & 0.231 & 0.231 & 0.011 & 0.1970 & 0.197 & 0.197 & 0.011 & 0.1684 \\
\hline 16 & NO3 & 0.146 & 0.146 & 0.000 & 0.1203 & 0.120 & 0.120 & 0.000 & 0.1018 & 0.102 & 0.102 & 0.000 & 0.0861 \\
\hline \begin{tabular}{|c|}
17 \\
\end{tabular} & $\mathrm{OH}$ & 0.551 & 0.551 & 0.010 & 0.4555 & 0.455 & 0.455 & 0.010 & 0.3869 & 0.387 & 0.387 & 0.010 & 0.3289 \\
\hline 18 & & 0.007 & 0.007 & 0.000 & 0.0057 & 0.006 & 0.006 & 0.000 & 0.0048 & 0.005 & 0.005 & 0.000 & 0.0041 \\
\hline 19 & 504 & 0.020 & 0.020 & 0.000 & 0.0168 & 0.017 & 0.017 & 0.000 & 0.0142 & 0.014 & 0.014 & 0.000 & 0.0120 \\
\hline 20 & & 0.000 & 0.000 & 0.000 & 0.0004 & 0.000 & 0.000 & 0.000 & 0.0003 & 0.000 & 0.000 & 0.000 & 0.0003 \\
\hline 21 & $\mathrm{CO}_{-2}-2$ & 0.056 & 0.056 & 0.000 & 0.0458 & 0.046 & 0.046 & 0.000 & 0.0388 & 0.039 & 0.039 & 0.000 & 0.0328 \\
\hline 22 & $\mathrm{NO2} 2$ & 0.088 & 0.088 & 0.000 & 0.0727 & 0.073 & 0.073 & 0.000 & 0.0615 & 0.062 & 0.062 & 0.000 & 0.0521 \\
\hline 23 & $\mathrm{C} 2 \mathrm{O} 4-2$ & 0.000 & 0.000 & 0.000 & 0.0003 & 0.000 & 0.000 & 0.000 & 0.00022 & 0.000 & 0.000 & 0.000 & 0.00018 \\
\hline 24 & $\mathrm{PO} 4-3$ & 0.001 & 0.001 & 0.000 & 0.0006 & 0.001 & 0.001 & 0.000 & 0.0005 & 0.001 & 0.001 & 0.000 & 0.0004 \\
\hline $25 \mid$ & & 0.002 & 0.002 & 0.000 & 0.0017 & 0.002 & 0.002 & 0.000 & 0.0015 & 0.001 & 0.001 & 0.000 & 0.0012 \\
\hline 26 & Soluble $\mathrm{Na} 2 \mathrm{C} 2 \mathrm{O} 4, \mathrm{M}$ & & & & & & & & 0.13503 & & & & 0.017044 \\
\hline \begin{tabular}{|l|}
20 \\
27 \\
\end{tabular} & Insol $\mathrm{Na} 2 \mathrm{C} 204, \mathrm{~kg}$ & & 0 & & & & 0 & & 0.030 & & 0 & & 0.1704 \\
\hline 28 & Heat Load & $(\mathrm{Na}) \mathrm{S} . \mathrm{S} .=$ & 75.562 & & & $(\mathrm{Na}) \mathrm{I}, \mathrm{S} .=$ & 13.215 & & & $(\mathrm{Na}) \mathrm{l}, \mathrm{S} .=$ & 11.223 & & \\
\hline 29 & Sludge $\mathrm{b} / \mathrm{g}$ & 0 & 145212 & 0.0 & 145212 & 0 & 145212 & 0.0 & 145212 & 0 & 145212 & 0.0 & 145212 \\
\hline \begin{tabular}{|l|}
30 \\
\end{tabular} & Sludge a & 0 & 14402 & 0.0 & 14402 & 0 & 14402 & 0.0 & 14402 & 0 & 14402 & 0.0 & 14402 \\
\hline \begin{tabular}{|l|}
31 \\
\end{tabular} & supernate $\mathrm{b} / \mathrm{g}$ & 288 & 1338 & 0.0 & 1338 & 206 & 1133 & 0.0 & 1133 & 174 & 958 & 0.0 & 958 \\
\hline \begin{tabular}{|l|}
32 \\
\end{tabular} & supernate a & 9 & 41 & 0.0 & 41 & 6 & 35 & 0.0 & 35 & 5 & 30 & 0.0 & 30 \\
\hline \begin{tabular}{|l|}
33 \\
\end{tabular} & Temperature Basis. C & & & & 40 & & & & 40 & & & & 40 \\
\hline \begin{tabular}{|l|}
34 \\
\end{tabular} & C-LFL (corrected) & & & & 0.03734 & & & & 0.03734 & & & & 0.03734 \\
\hline \begin{tabular}{|l|l|}
35 \\
\end{tabular} & NOeff $(M)$ & & & & 0.2305 & & & & 0.1958 & & & & 0.1665 \\
\hline \begin{tabular}{|l|}
36 \\
\end{tabular} & $\mathrm{Rb} / \mathrm{g}$ & & & & 21.41 & & & & 22.56 & & & & 23.67 \\
\hline 37 & $\mathrm{Ra}$ & & & & 81.83 & & & & 84.61 & & & & 87.24 \\
\hline 38 & $\mathrm{H} 2 \mathrm{~b} / \mathrm{g}$ & & & & 3.14 & & & & 3.30 & & & & 3.46 \\
\hline 39 & H2 alpha & & & & 1.18 & & & & 1.22 & & & & 1.26 \\
\hline 40 & Total H2 (cuft/hr) & & & & 4.32 & & & & 4.52 & & & & 4.72 \\
\hline \begin{tabular}{|l|}
41 \\
\end{tabular} & $Q(\mathrm{H} 2)$, Temp Corrected & & & & 4.95 & & & & 5.19 & & & & 5.41 \\
\hline 42 & W, fl3 (for seismic) & & & & 95774 & & & & 95774 & & & & 95774 \\
\hline$\frac{43}{44}$ & tume of $25 \%$ LLL, instant release, & & & & & & & & & & & & \\
\hline \begin{tabular}{|l|}
45 \\
\end{tabular} & yo & & & & 0.007835 & & & & 0.007835 & & & & 0.007835 \\
\hline 46 & HLLCP & & & & 197.00 & & & & 197.00 & & & & 197.00 \\
\hline 47 & Flammability Level & & & & 203.274 & & & & 203.274 & & & & 203.274 \\
\hline 48 & $\mathrm{~W}, \mathrm{f} 3$ (for vent loss) & & & & 88,142 & & & & 88,142 & & & & 88,142 \\
\hline 49 & $Q$ (for vent loss) & & & & 18.127 & & & & 18.127 & & & & 18.127 \\
\hline 50 & Days to LFL (vent loss) & & & & 24.50 & & & & 23.30 & & & & 22.25 \\
\hline 51 & Flammability Classification & & & & rapid & & & & rapid & & & & rapid \\
\hline 52 & Q. seismic & & & & 19.70 & & & & 19.70 & & & & 19.70 \\
\hline 53 & Seismic Q-time, days & & & & 17.95 & & & & 16.83 & & & & 15.85 \\
\hline 54 & Mass TS, kg & & & & & & & & & & & & \\
\hline \begin{tabular}{|l|l|}
59 \\
\end{tabular} & wt\% TS & & & & & & & & & & & & \\
\hline
\end{tabular}


SRNL-STI-2010-00353

Revision 0

Appendix B. SRNL Sludge Batch 6 Washing Mass Balance 
SRNL-STI-2010-00353

Revision 0

NOTE: The information presented in this appendix was published previously in memorandum SRNL-L3100-2010-00082, Balance During SRNL Washing of Sludge Batch 6 Qualification Sample.

Presented below is the mass balance during washing of the SRNL Sludge Batch 6 Qualification sample. Also included are an insoluble solids balance, volume observations throughout washing, and volumes of additions and removals (calculated from mass and density).

Please note the following:

- The mass of the as-received sample was measured. After that measurement, only the masses of additions and removals were measured.

- Weight percent insoluble solids were calculated from total solids and dissolved solids measurements.

- Volumes were calculated based on measured or estimated densities.

- Because volume is not conserved, a running volume balance is not presented. However, observed volumes and volumes of additions and removals (based on mass and density) are given.

The $\mathrm{wt} \%$ insoluble solids after Decant I was determined to be $9.9 \mathrm{wt} \%$. Based on the mass balance and the wt\% insoluble solids, the total mass of insoluble solids after Decant I is calculated to be

$9.9 / 100 \times 2314=229 \mathrm{~g}$,

or only $7 \%$ higher than the mass of insoluble solids ( $214 \mathrm{~g})$ calculated from the mass balance. This suggests that there was no significant precipitation or dissolving of insoluble solids during washing at SRNL.

\section{Explanation of Table Headings}

Note that removals or subtractions are designated by placement in parentheses

Addition or ((Removal) - mass of material added or removed during a given washing step.

Running Total - sum of additions and removals.

Insoluble Solids ( $\mathrm{wt} \%$ ) - the determined $\mathrm{wt} \%$ insoluble solids at a given point during washing.

Insoluble Solids Added (Removed) - the mass of insoluble solids added or removed based on the sample size and the determined $\mathrm{wt} \%$ insoluble solids.

Insoluble Solids Running Total - the sum of insoluble solids additions and removals.

Observed Total Volume - the total volume based on the graduations on the SRNL washing vessel. Note that observations were taken after each addition to track sludge settling.

Density of Add'n or Removal - the measured or estimated density of additions and removals. The density of the decants and sludge samples were measured. The densities of additions were estimated (e.g., the density of inhibited water was estimated to be $1.0 \mathrm{~g} / \mathrm{mL}$ ).

Calculated Volume Added (Removed) - the mass of an addition or removal divided by the density. 
SRNL-STI-2010-00353

Revision 0

\begin{tabular}{|c|c|c|c|c|c|c|c|c|}
\hline & $\begin{array}{l}\text { Addition or } \\
\text { (Removal) } \\
\text { (g) }\end{array}$ & $\begin{array}{l}\text { Running } \\
\text { Total } \\
(\mathrm{g})\end{array}$ & $\begin{array}{c}\text { Insoluble } \\
\text { Solids } \\
(\mathrm{wt} \%)\end{array}$ & $\begin{array}{c}\text { Insoluble } \\
\text { Solids Added } \\
\text { (Removed) } \\
\text { (g) }\end{array}$ & $\begin{array}{l}\text { Insoluble } \\
\text { Solids } \\
\text { Running } \\
\text { Total } \\
\text { (g) }\end{array}$ & $\begin{array}{c}\text { Observed } \\
\text { Total Volume } \\
(\mathrm{mL})\end{array}$ & $\begin{array}{l}\text { Density of } \\
\text { Add'n or } \\
\text { Removal } \\
(\mathrm{g} / \mathrm{mL})\end{array}$ & $\begin{array}{l}\text { Calculated } \\
\text { Volume } \\
\text { Added } \\
\text { (Removed) } \\
\text { (mL) }\end{array}$ \\
\hline Initial Sample & $4,211.04$ & 4,211 & 6.0 & 253 & 253 & 3,100 & 1.38 & 3,051 \\
\hline Subsample Removed & $(530.16)$ & 3,681 & 6.0 & $(32)$ & 221 & 2,700 & 1.38 & $(384)$ \\
\hline Decant A & $(493.49)$ & 3,187 & - & - & 221 & - & 1.36 & $(363)$ \\
\hline Wash B Additions ${ }^{\text {a }}$ & $1,219.75$ & 4,407 & - & - & 221 & 3,450 & 1.08 & 1,129 \\
\hline Decant B & $(1,124.05)$ & 3,283 & - & - & 221 & - & 1.26 & $(892)$ \\
\hline Wash C Additions ${ }^{a}$ & 960.05 & 4,243 & - & - & 221 & 3,450 & 1.00 & 960 \\
\hline Decant C & $(1,113.61)$ & 3,130 & - & - & 221 & - & 1.20 & $(928)$ \\
\hline Post Decant C Slurry Subsample & $(55.40)$ & 3,074 & 6.3 & (3) & 217 & - & 1.27 & $(44)$ \\
\hline Wash D & 776.28 & 3,850 & - & - & 217 & 3,200 & 1.00 & 776 \\
\hline Decant D & $(843.82)$ & 3,007 & - & - & 217 & - & 1.15 & $(734)$ \\
\hline Wash E & 862.74 & 3,869 & - & - & 217 & 3,300 & 1.00 & 863 \\
\hline Decant E & $(839.25)$ & 3,030 & - & - & 217 & - & 1.12 & $(749)$ \\
\hline Wash F ${ }^{b}$ & 794.88 & 3,825 & - & - & 217 & 3,300 & 1.04 & 764 \\
\hline Decant F & $(840.34)$ & 2,985 & - & - & 217 & - & 1.11 & $(757)$ \\
\hline Post Decant F Slurry Subsample & $(53.03)$ & 2,932 & 7.1 & (4) & 214 & - & 1.17 & $(45)$ \\
\hline Wash G & 791.25 & 3,723 & - & - & 214 & 3,250 & 1.00 & 791 \\
\hline Decant $\mathrm{G}$ & $(736.68)$ & 2,986 & - & - & 214 & - & 1.08 & $(682)$ \\
\hline Wash H & 695.24 & 3,681 & - & - & 214 & 3,250 & 1.00 & 695 \\
\hline Decant $\mathrm{H}$ & $(579.21)$ & 3,102 & - & - & 214 & - & 1.06 & $(546)$ \\
\hline Wash I & 550.93 & 3,653 & - & - & 214 & 3,250 & 1.00 & 551 \\
\hline Decant I Supernate Subsample ${ }^{c}$ & $(57.45)$ & 3,596 & - & - & 214 & - & 1.06 & $(54)$ \\
\hline Decant I & $(1,281.29)$ & 2,314 & - & - & 214 & - & 1.06 & $(1,209)$ \\
\hline Post Decant I Sludge & - & 2,314 & 9.9 & - & $229 *$ & $2,050 * *$ & 1.13 & $N A$ \\
\hline
\end{tabular}

* The Post Decant I slurry had an insoluble solids content of $9.9 \mathrm{wt} \%$ (calculated from measured total and dissolved solids). Based on this insoluble solids result, the calculated insoluble solids mass is $2,314 \times 0.099=229 \mathrm{~g}$.

** The final Post Decant I slurry volume is calculated to be $2314 \mathrm{~g} / 1.13 \mathrm{~g} / \mathrm{mL}=2,050 \mathrm{~mL}$.

${ }^{a}$ Wash $\mathrm{B}$ and $\mathrm{C}$ additions included a Pu stream from $\mathrm{H}$ Canyon, neutralized to $1.2 \mathrm{M}$ excess hydroxide, along with additional sodium hydroxide to simulate flushes from $\mathrm{H}$ Canyon.

${ }^{\mathrm{b}}$ Wash $\mathrm{F}$ additions included significant sodium nitrite.

${ }^{c}$ A small sample of supernate was taken for analysis during Wash I settling. The results were used in the decision to stop washing at Wash I 
SRNL-STI-2010-00353

Revision 0

Appendix C. SRNL Sludge Batch 6 Analytical Results 
SRNL-STI-2010-00353

Revision 0

Presented in this appendix are more compete analytical results from sludge washing and the CPC simulations. These tables include additional analytes and relative standard deviations.

Table C - 1. Density and Weight Percent Solids for Tank 51 SB6 Qualification Sample

\begin{tabular}{|c|c|c||}
\hline Property & Result & \%Rsd \\
\hline Slurry Density & 1.38 & 0.3 \\
\hline Supernate Density & 1.36 & 0.4 \\
\hline $\begin{array}{c}\text { Wt\% Total Solids } \\
\text { (Slurry Basis) }\end{array}$ & 38.0 & 0.5 \\
\hline $\begin{array}{c}\mathrm{Wt} \% \text { Calcined Solids } \\
\text { (Slurry Basis) }\end{array}$ & 25.6 & 0.6 \\
\hline $\begin{array}{c}\mathrm{Wt} \% \text { Dissolved Solids } \\
\text { (Supernate Basis) }\end{array}$ & 34.0 & 0.1 \\
\hline $\begin{array}{c}\mathrm{Wt} \% \text { Soluble Solids } \\
\text { (Slurry Basis) }\end{array}$ & 32.0 & $0.2^{c}$ \\
\hline $\begin{array}{c}\text { Wt\% Insoluble Solids } \\
\text { (Slurry Basis) }\end{array}$ & 6.0 & $2.5^{c}$ \\
\hline
\end{tabular}

${ }^{a}$ Also known as Uncorrected Soluble Solids

${ }^{\mathrm{b}}$ Also known as Corrected Soluble Solids

c \%RSD here is more correctly defined as \% standard error for these calculated values

Values in the \%RSD column are relative to the true calculated averages of the quantities in the tables, while the average values reported have been rounded off to a reasonable number of significant figures. 
Table C - 2. Concentrations of Elements in Total Dried Solids and Calcined Solids for the AsReceived Tank 51 SB6 Qualification Sample

\begin{tabular}{|c|c|c|c|c|c|}
\hline Element & $\begin{array}{c}\text { Wt\% Total } \\
\text { Solids }\end{array}$ & $\begin{array}{c}\text { Wt\% Calcine } \\
\text { Solids } \\
\end{array}$ & \%Rsd & Instrument & $\begin{array}{c}\text { Prep } \\
\text { Method }\end{array}$ \\
\hline $\mathrm{Ag}$ & 0.00288 & 0.00428 & 3.9 & ICP-MS & $\mathrm{AR}$ \\
\hline $\mathrm{Al}$ & 6.01 & 8.93 & 1.2 & ICP-AES & $\mathrm{PF}$ \\
\hline $\mathrm{B}$ & 0.0106 & 0.0158 & 5.4 & ICP-AES & AR \\
\hline $\mathrm{Ba}$ & 0.0227 & 0.0337 & 2.3 & ICP-AES & $\mathrm{AR} / \mathrm{PF}$ \\
\hline $\mathrm{Be}$ & 0.000147 & 0.000219 & 2.8 & ICP-AES & AR \\
\hline $\mathrm{Ca}$ & 0.140 & 0.207 & 2.1 & ICP-AES & AR \\
\hline $\mathrm{Cd}$ & 0.00198 & 0.00294 & 8.8 & ICP-MS & AR \\
\hline $\mathrm{Ce}$ & 0.0336 & 0.0499 & 0.8 & ICP-MS & AR \\
\hline $\mathrm{Cr}$ & 0.0536 & 0.0795 & 6.0 & ICP-AES & $\mathrm{AR} / \mathrm{PF}$ \\
\hline $\mathrm{Cu}$ & 0.0174 & 0.0258 & 2.9 & ICP-AES & $\mathrm{AR} / \mathrm{PF}$ \\
\hline $\mathrm{Fe}$ & 2.87 & 4.26 & 2.5 & ICP-AES & $\mathrm{AR} / \mathrm{PF}$ \\
\hline $\mathrm{Gd}$ & 0.00724 & 0.0107 & 8.1 & ICP-MS & $\mathrm{AR}$ \\
\hline $\mathrm{Hg}$ & 0.872 & - & 6.6 & CVAA & $\mathrm{AR}$ \\
\hline $\mathrm{K}$ & 0.117 & 0.173 & 6.6 & ICP-AES & AR \\
\hline $\mathrm{La}$ & 0.0170 & 0.0253 & 1.9 & ICP-MS & AR \\
\hline $\mathrm{Li}$ & 0.00445 & 0.00661 & 2.5 & ICP-AES & $\mathrm{AR}$ \\
\hline $\mathrm{Mg}$ & 0.0524 & 0.0778 & 2.4 & ICP-AES & $\mathrm{AR} / \mathrm{PF}$ \\
\hline $\mathrm{Mn}$ & 1.02 & 1.51 & 1.3 & ICP-AES & $\mathrm{AR} / \mathrm{PF}$ \\
\hline Mo & 0.00826 & 0.0123 & 7.3 & ICP-AES & $\mathrm{AR}$ \\
\hline $\mathrm{Na}$ & 30.2 & 44.8 & 9.0 & ICP-AES & AR \\
\hline $\mathrm{Nd}$ & 0.0627 & 0.0931 & 0.5 & ICP-MS & $\mathrm{AR}$ \\
\hline $\mathrm{Ni}$ & 0.415 & 0.617 & 2.4 & ICP-AES & $\mathrm{AR} / \mathrm{PF}$ \\
\hline $\mathrm{P}$ & $0.0571 \dagger$ & 0.0847 & 10 & ICP-AES & $\mathrm{AR}$ \\
\hline $\mathrm{Pb}$ & 0.00434 & 0.00645 & 3.9 & ICP-MS & AR \\
\hline $\mathrm{S}$ & 1.04 & 1.54 & 2.9 & ICP-AES & AR \\
\hline $\mathrm{Sb}$ & $<0.0092$ & $<0.014$ & - & ICP-AES & AR \\
\hline $\mathrm{Si}$ & 0.178 & 0.264 & 5.1 & ICP-AES & $\mathrm{PF}$ \\
\hline $\mathrm{Sn}$ & $<0.0043$ & $<0.0064$ & - & ICP-AES & AR \\
\hline $\mathrm{Sr}$ & 0.0106 & 0.0158 & 2.4 & ICP-AES & $\mathrm{AR} / \mathrm{PF}$ \\
\hline $\mathrm{Ti}$ & 0.00413 & 0.00613 & 9.4 & ICP-AES & $\mathrm{AR} / \mathrm{PF}$ \\
\hline $\mathrm{Th}$ & 0.731 & 1.08 & 2.4 & ICP-MS & $\mathrm{AR}$ \\
\hline $\mathrm{U}$ & 0.601 & 0.892 & 1.1 & ICP-MS & AR \\
\hline $\mathrm{V}$ & $<0.00059$ & $<0.00088$ & - & ICP-AES & AR \\
\hline $\mathrm{Zn}$ & 0.0138 & 0.0204 & 11 & ICP-AES & $\mathrm{AR} / \mathrm{PF}$ \\
\hline $\mathrm{Zr}$ & 0.057 & 0.085 & 32 & ICP-AES & $\mathrm{AR}$ \\
\hline
\end{tabular}

Results are Averages of Dissolution and Analysis of Four to Eight Aliquots of the SB6 Slurry.

$\dagger$ Reported result is the average of three replicates.

ICP-MS $\equiv$ inductively coupled plasma - mass spectrometry, ICP-AES $\equiv$ inductively coupled plasma atomic emission spectroscopy, $\mathrm{CVAA} \equiv$ cold vapor atomic absorption spectroscopy, $\mathrm{AR} \equiv$ aqua regia digestion, $\mathrm{PF} \equiv$ peroxide fusion

Values in the \%RSD column are relative to the true calculated averages of the quantities in the tables, while the average values reported have been rounded off to a reasonable number of significant figures. 
Table C - 3. Concentrations of Noble Metals and Silver in Total Dried Solids for the As-Received Tank 51 SB6 Qualification Sample

\begin{tabular}{|c|c|c|}
\hline Element & Wt\% Total Solids & \%RSD \\
\hline $\mathrm{Ru}$ & 0.0227 & 0.7 \\
\hline $\mathrm{Rh}$ & 0.00471 & 1.1 \\
\hline $\mathrm{Pd}$ & 0.00134 & 1.9 \\
\hline $\mathrm{Ag}$ & 0.00288 & 3.9 \\
\hline
\end{tabular}

Results are Averages of Aqua Regia Digestions and ICP-MS Analyses of Four SB6 Slurry Aliquots . Values in the \%RSD column are relative to the true calculated averages of the quantities in the tables, while the average values reported have been rounded off to a reasonable number of significant figures.

Table C - 4. Concentrations of Soluble Elements in the As-Received SB6 Qualification Sample Supernate

\begin{tabular}{|c|c|c|}
\hline Element & Molarity & \%RSD \\
\hline $\mathrm{Al}$ & 0.798 & 1.0 \\
\hline $\mathrm{B}$ & 0.00557 & 0.2 \\
\hline $\mathrm{Ca}$ & $0.000153^{*}$ & 5.4 \\
\hline $\mathrm{Cr}$ & 0.00511 & 0.3 \\
\hline $\mathrm{Fe}$ & $0.000105 * *$ & 4.5 \\
\hline $\mathrm{K}$ & 0.0188 & 3.4 \\
\hline Mo & 0.000509 & 2.0 \\
\hline $\mathrm{Na}$ & 8.55 & 1.0 \\
\hline $\mathrm{P}$ & 0.00654 & 1.5 \\
\hline $\mathrm{S}$ & 0.181 & 2.2 \\
\hline $\mathrm{Zn}$ & 0.0000751 & 3.0 \\
\hline
\end{tabular}

Results are Averages of Four SB6 Supernate Aliquots, diluted in acid, and analyzed by ICP-AES.

* Result is the average of three measurements.

** Result is the average of two measurements.

Values in the \%RSD column are relative to the true calculated averages of the quantities in the tables, while the average values reported have been rounded off to a reasonable number of significant figures.

Table C - 5. Concentrations of Anions on a Supernate Basis for the As-Received Tank 51 SB6 Qualification Sample

\begin{tabular}{||c|c|c||}
\hline Anion & Molarity & \%RSD \\
\hline $\mathrm{Br}^{-}$ & $<0.032$ & - \\
\hline $\mathrm{Cl}^{-}$ & $<0.073$ & - \\
\hline $\mathrm{F}^{-}$ & $<0.14$ & - \\
\hline $\mathrm{HCO}_{2}{ }^{-}$ & $<0.057$ & - \\
\hline $\mathrm{NO}_{3}{ }^{-}$ & 1.27 & 4.9 \\
\hline $\mathrm{NO}_{2}{ }^{2-}$ & 1.27 & 4.7 \\
\hline $\mathrm{CO}_{3}{ }^{2-}$ & 0.503 & 1.2 \\
\hline $\mathrm{C}_{2} \mathrm{O}_{4}{ }^{3-}$ & $<0.029$ & - \\
\hline $\mathrm{PO}_{4}{ }^{2-}$ & $<0.027$ & - \\
\hline $\mathrm{SO}_{4}$ & 0.184 & 10 \\
\hline
\end{tabular}

Results are averages of four SB6 supernate aliquots diluted with water and analyzed by IC.

Values in the \%RSD column are relative to the true calculated averages of the quantities in the tables, while the average values reported have been rounded off to a reasonable number of significant figures. 
Table C - 6. Supernate Concentrations of Total Base, Free Hydroxide, and Other Bases Excluding Carbonate for the As-Received Tank 51 SB6 Qualification Sample.

\begin{tabular}{|c|c|c||}
\hline Species & Molarity & \%RSD \\
\hline Total Base & 5.07 & 0.8 \\
\hline Free $\mathrm{OH}^{-}$ & 3.53 & 0.7 \\
\hline $\begin{array}{c}\text { Other Base } \\
\text { Excluding } \mathrm{CO}_{3}{ }^{2-}\end{array}$ & 1.06 & 5.5 \\
\hline
\end{tabular}

Values in the \%RSD column are relative to the true calculated averages of the quantities in the tables, while the average values reported have been rounded off to a reasonable number of significant figures.

Table C - 7. Decant B (Supernate) Analysis

\begin{tabular}{|c|c|c|c|}
\hline & Unit & Result & \%RSD \\
\hline Supernate Density & $\mathrm{g} / \mathrm{mL}$ & 1.26 & 0.8 \\
\hline Fluoride & molar & $<0.028$ & \\
\hline Formate & molar & $<0.012$ & \\
\hline Chloride & molar & 0.0137 & 2.9 \\
\hline Nitrite & molar & 0.752 & 0.5 \\
\hline Bromide & molar & $<0.0065$ & \\
\hline Nitrate & molar & 0.756 & 0.5 \\
\hline Phosphate & molar & $<0.028$ & \\
\hline Sulfate & molar & 0.0980 & 1.0 \\
\hline Oxalate & molar & $<0.0059$ & \\
\hline $\mathrm{Al}$ & molar & 0.484 & 2.3 \\
\hline $\mathrm{B}$ & molar & 0.00347 & 2.6 \\
\hline $\mathrm{Cr}$ & molar & 0.00311 & 1.8 \\
\hline $\mathrm{K}$ & molar & 0.0113 & 3.1 \\
\hline Mo & molar & 0.000296 & 2.9 \\
\hline $\mathrm{Na}$ & molar & 6.09 & 1.9 \\
\hline $\mathrm{P}$ & molar & 0.00396 & 2.3 \\
\hline $\mathrm{S}$ & molar & 0.109 & 4.0 \\
\hline $\mathrm{Si}$ & molar & 0.000474 & 0.5 \\
\hline $\mathrm{Zn}$ & molar & $3.51 \mathrm{E}-05$ & 9.2 \\
\hline
\end{tabular}

Results are averages of four measurements. Anions are determined from IC, and elementals from ICPAES.

Values in the $\%$ RSD column are relative to the true calculated averages of the quantities in the tables, while the average values reported have been rounded off to a reasonable number of significant figures. 
Table C - 8. Decant C (Supernate) Analysis

\begin{tabular}{|c|c|c|c|}
\hline & Unit & Result & \%RSD \\
\hline Supernate Density & $\mathrm{g} / \mathrm{mL}$ & 1.27 & 0.7 \\
\hline Fluoride & molar & $<0.013$ & \\
\hline Formate & molar & $<0.0056$ & \\
\hline Chloride & molar & $<0.0072$ & \\
\hline Nitrite & molar & 0.498 & 0.3 \\
\hline Bromide & molar & $<0.0032$ & \\
\hline Nitrate & molar & 0.493 & 0.3 \\
\hline Phosphate & molar & $<0.0027$ & \\
\hline Sulfate & molar & 0.0676 & 0.7 \\
\hline Oxalate & molar & $<0.0029$ & \\
\hline $\mathrm{Al}$ & molar & 0.355 & 0.5 \\
\hline $\mathrm{B}$ & molar & 0.00243 & 0.6 \\
\hline $\mathrm{Be}$ & molar & 5.89E-06 & 1.5 \\
\hline $\mathrm{Ca}$ & molar & $6.18 \mathrm{E}-05$ & 3.2 \\
\hline $\mathrm{Cr}$ & molar & 0.00230 & 0.5 \\
\hline $\mathrm{Fe}$ & molar & $2.13 \mathrm{E}-05$ & 7.4 \\
\hline $\mathrm{K}$ & molar & 0.00829 & 3.4 \\
\hline $\mathrm{Mg}$ & molar & $1.94 \mathrm{E}-05$ & 13 \\
\hline Mo & molar & $2.21 \mathrm{E}-04$ & 0.7 \\
\hline $\mathrm{Na}$ & molar & 4.41 & 0.9 \\
\hline $\mathrm{P}$ & molar & 0.00285 & 1.9 \\
\hline $\mathrm{Pb}$ & molar & $4.39 \mathrm{E}-05$ & na \\
\hline $\mathrm{S}$ & molar & 0.0725 & 1.4 \\
\hline $\mathrm{Si}$ & molar & $3.62 \mathrm{E}-04$ & 7.4 \\
\hline $\mathrm{Zn}$ & molar & $5.92 \mathrm{E}-05$ & 1.4 \\
\hline
\end{tabular}

Results are averages of four measurements. Anions are determined from IC, and elementals from ICPAES.

Values in the \%RSD column are relative to the true calculated averages of the quantities in the tables, while the average values reported have been rounded off to a reasonable number of significant figures.

Table C - 9. Post Decant C Slurry and Supernate Density and Weight Percent Solids

\begin{tabular}{|c|c|c||}
\hline Property & Result & \%RSD \\
\hline Slurry Density & 1.27 & 0.7 \\
\hline Supernate Density & 1.20 & 0.2 \\
\hline $\begin{array}{c}\text { Wt\% Total Solids (Slurry } \\
\text { Basis) }\end{array}$ & 26.51 & 0.2 \\
\hline $\begin{array}{c}\mathrm{Wt} \% \text { Dissolved Solids } \\
\text { (Supernate Basis) }\end{array}$ & 21.56 & 1.1 \\
\hline $\begin{array}{c}\mathrm{Wt} \% \text { Soluble Solids } \\
\text { (Slurry Basis) }\end{array}$ & 6.31 & NA \\
\hline $\begin{array}{c}\text { Wt\% Insoluble Solids } \\
\text { (Slurry Basis) }\end{array}$ & & \\
\hline
\end{tabular}

Values in the \%RSD column are relative to the true calculated averages of the quantities in the tables, while the average values reported have been rounded off to a reasonable number of significant figures. 
Table C - 10. Post Decant C Aqua Regia Digestion of Total Solids

\begin{tabular}{||c|c|c|c|c|c||}
\hline Element & $\begin{array}{c}\text { Wt \% of Total } \\
\text { Solids }\end{array}$ & \%RSD & Element & $\begin{array}{c}\text { Wt \%of Total } \\
\text { Solids }\end{array}$ & \%RSD \\
\hline $\mathrm{Al}$ & 5.98 & 4.2 & $\mathrm{Mg}$ & 0.0917 & 2.2 \\
\hline $\mathrm{Ba}$ & 0.0390 & 2.5 & $\mathrm{Mn}$ & 1.75 & 2.1 \\
\hline $\mathrm{Ca}$ & 0.242 & 2.6 & $\mathrm{Mo}$ & 0.00700 & 3.2 \\
\hline $\mathrm{Cd}$ & 0.00321 & 4.8 & $\mathrm{Na}$ & 29.5 & 2.6 \\
\hline $\mathrm{Ce}$ & 0.0582 & 2.2 & $\mathrm{Ni}$ & 0.677 & 2.8 \\
\hline $\mathrm{Cr}$ & 0.0453 & 2.0 & $\mathrm{P}$ & 0.0718 & 20 \\
\hline $\mathrm{Cu}$ & 0.0298 & 2.5 & $\mathrm{~S}$ & 0.785 & 4.2 \\
\hline $\mathrm{Fe}$ & 4.80 & 2.0 & $\mathrm{Si}$ & 0.206 & 4.0 \\
\hline $\mathrm{Gd}$ & 0.0346 & 3.2 & $\mathrm{Sr}$ & 0.0182 & 2.5 \\
\hline $\mathrm{Hg}$ & 2.05 & 4.2 & $\mathrm{Ti}$ & 0.00702 & 1.9 \\
\hline $\mathrm{K}$ & 0.0949 & 1.3 & $\mathrm{U}$ & 1.11 & 3.3 \\
\hline $\mathrm{La}$ & 0.0225 & 3.1 & $\mathrm{Zn}$ & 0.0182 & 3.7 \\
\hline $\mathrm{Li}$ & 0.00768 & 3.5 & $\mathrm{Zr}$ & 0.0741 & 33 \\
\hline
\end{tabular}

Values in the \%RSD column are relative to the true calculated averages of the quantities in the tables, while the average values reported have been rounded off to a reasonable number of significant figures.

Table C - 11. Decant D (Supernate) Analysis

\begin{tabular}{|c|c|c|c|}
\hline & Unit & Result & \%RSD \\
\hline Supernate Density & $\mathrm{g} / \mathrm{mL}$ & 1.15 & 0.7 \\
\hline Fluoride & molar & $<0.014$ & \\
\hline Formate & molar & $<0.0060$ & \\
\hline Chloride & molar & $<0.0076$ & \\
\hline Nitrite & molar & 0.440 & 0.2 \\
\hline Bromide & molar & $<0.0034$ & \\
\hline Nitrate & molar & 0.449 & 0.2 \\
\hline Phosphate & molar & $<0.0030$ & \\
\hline Sulfate & molar & 0.0484 & 0.3 \\
\hline Oxalate & molar & $<0.0032$ & \\
\hline $\mathrm{Al}$ & molar & 0.258 & 3.1 \\
\hline $\mathrm{B}$ & molar & 0.00191 & 2.7 \\
\hline $\mathrm{Ca}$ & molar & $6.11 \mathrm{E}-05$ & 22 \\
\hline $\mathrm{Cr}$ & molar & 0.00144 & 3.2 \\
\hline $\mathrm{Fe}$ & molar & $7.05 \mathrm{E}-05$ & 98 \\
\hline $\mathrm{K}$ & molar & 0.00574 & 7.1 \\
\hline Mo & molar & $1.65 \mathrm{E}-04$ & 3.0 \\
\hline $\mathrm{Na}$ & molar & 3.25 & 2.7 \\
\hline $\mathrm{P}$ & molar & 0.00201 & 4.4 \\
\hline $\mathrm{S}$ & molar & 0.0582 & 2.7 \\
\hline $\mathrm{Zn}$ & molar & $2.60 \mathrm{E}-05$ & 4.3 \\
\hline
\end{tabular}

Results are averages of four measurements. Anions are determined from IC, and elementals from ICPAES.

Values in the $\%$ RSD column are relative to the true calculated averages of the quantities in the tables, while the average values reported have been rounded off to a reasonable number of significant figures. 
SRNL-STI-2010-00353

Revision 0

Table C - 12. Decant E (Supernate) Analysis

\begin{tabular}{|c|c|c|c|}
\hline & Unit & Result & \%RSD \\
\hline Supernate Density & $\mathrm{g} / \mathrm{mL}$ & 1.12 & 0.4 \\
\hline Fluoride & molar & $<0.0066$ & NA \\
\hline Formate & molar & $<0.0028$ & $\mathrm{NA}$ \\
\hline Chloride & molar & $<0.0035$ & $\mathrm{NA}$ \\
\hline Nitrite & molar & 0.262 & 3.5 \\
\hline Bromide & molar & $<0.0016$ & $\mathrm{NA}$ \\
\hline Nitrate & molar & 0.285 & 3 \\
\hline Phosphate & molar & $<0.0013$ & $\mathrm{NA}$ \\
\hline Sulfate & molar & 0.0421 & 14 \\
\hline Oxalate & molar & $<0.0014$ & NA \\
\hline $\mathrm{Al}$ & molar & 0.190 & 1.6 \\
\hline $\mathrm{B}$ & molar & 0.00144 & 0.5 \\
\hline $\mathrm{Ca}$ & molar & $2.10 \mathrm{E}-05$ & 4 \\
\hline $\mathrm{Cr}$ & molar & 0.00124 & 1.4 \\
\hline $\mathrm{K}$ & molar & 0.00477 & 0.4 \\
\hline Mo & molar & $1.23 \mathrm{E}-04$ & 3.1 \\
\hline $\mathrm{Na}$ & molar & 2.45 & 1.4 \\
\hline $\mathrm{P}$ & molar & 0.00154 & 2.4 \\
\hline $\mathrm{S}$ & molar & 0.0488 & 2.0 \\
\hline $\mathrm{Zn}$ & molar & $9.77 \mathrm{E}-06$ & 14 \\
\hline
\end{tabular}

Results are averages of four measurements. Anions are determined from IC, and elementals from ICPAES.

Values in the \%RSD column are relative to the true calculated averages of the quantities in the tables, while the average values reported have been rounded off to a reasonable number of significant figures. 
Table C - 13. Decant F (Supernate) Analysis

\begin{tabular}{|c|c|c|c|}
\hline & Unit & Result & \%RSD \\
\hline Supernate Density & $\mathrm{g} / \mathrm{mL}$ & 1.11 & 0.4 \\
\hline Fluoride & molar & $<0.0064$ & $\mathrm{NA}$ \\
\hline Formate & molar & $<0.0027$ & NA \\
\hline Chloride & molar & $<0.0034$ & $\mathrm{NA}$ \\
\hline Nitrite & molar & 0.414 & 1.0 \\
\hline Bromide & molar & $<0.0015$ & $\mathrm{NA}$ \\
\hline Nitrate & molar & 0.213 & 1.2 \\
\hline Phosphate & molar & $<0.0013$ & $\mathrm{NA}$ \\
\hline Sulfate & molar & 0.0290 & 1.0 \\
\hline Oxalate & molar & $<0.0014$ & $\mathrm{NA}$ \\
\hline $\mathrm{Al}$ & molar & 0.153 & 0.4 \\
\hline $\mathrm{B}$ & molar & 0.00113 & 1.3 \\
\hline $\mathrm{Ca}$ & molar & $4.46 \mathrm{E}-05$ & 5.2 \\
\hline $\mathrm{Cr}$ & molar & 0.00100 & 2.1 \\
\hline $\mathrm{Fe}$ & molar & $2.74 \mathrm{E}-05$ & $\mathrm{NA}$ \\
\hline $\mathrm{K}$ & molar & 0.00369 & 8.9 \\
\hline Mo & molar & $9.60 \mathrm{E}-05$ & 2.9 \\
\hline $\mathrm{Na}$ & molar & 2.14 & 0.6 \\
\hline $\mathrm{P}$ & molar & 0.00121 & 4.6 \\
\hline $\mathrm{S}$ & molar & 0.0368 & 3.8 \\
\hline $\mathrm{Zn}$ & molar & $9.49 \mathrm{E}-06$ & 7.9 \\
\hline
\end{tabular}

Results are averages of four measurements. Anions are determined from IC, and elementals from ICPAES.

Values in the \%RSD column are relative to the true calculated averages of the quantities in the tables, while the average values reported have been rounded off to a reasonable number of significant figures.

Table C - 14. Post Decant F Slurry and Supernate Density and Weight Percent Solids

\begin{tabular}{||c|c|c|}
\hline Property & Result & \%RSD \\
\hline lurry Density & 1.17 & 1.2 \\
\hline $\begin{array}{c}\text { upernate Density } \\
\text { (Slurry Basis) }\end{array}$ & 1.11 & 0.4 \\
\hline $\begin{array}{c}\text { Wt\% Calcined Solids } \\
\text { (Slurry Basis) }\end{array}$ & 17.6 & 2.7 \\
\hline $\begin{array}{l}\text { Wt\% Dissolved Solids } \\
\text { Supernate Basis) }\end{array}$ & 13.2 & 0.4 \\
\hline $\begin{array}{c}\text { Wt\% Soluble Solids } \\
\text { (Slurry Basis) }\end{array}$ & 11.3 & NA \\
\hline $\begin{array}{c}\text { Wt\% Insoluble Solids } \\
\text { (Slurry Basis) }\end{array}$ & 7.1 & NA \\
\hline
\end{tabular}

Values in the \%RSD column are relative to the true calculated averages of the quantities in the tables, while the average values reported have been rounded off to a reasonable number of significant figures. 
Table C - 15. Post Decant F Aqua Regia Digestion of Total Solids

\begin{tabular}{|l|c|c|l|c|c||}
\hline Element & $\begin{array}{c}\text { Wt \% of Total } \\
\text { Solids }\end{array}$ & \%RSD & Element & $\begin{array}{c}\text { Wt \% of Total } \\
\text { Solids }\end{array}$ & \%RSD \\
\hline $\mathrm{Al}$ & 7.81 & 2.2 & $\mathrm{Mg}$ & 0.144 & 1.3 \\
\hline $\mathrm{Ba}$ & 0.0607 & 1.5 & $\mathrm{Mn}$ & 2.79 & 0.3 \\
\hline $\mathrm{Ca}$ & 0.357 & 0.6 & $\mathrm{Mo}$ & 0.00670 & 3.5 \\
\hline $\mathrm{Cd}$ & 0.00484 & 3.1 & $\mathrm{Na}$ & 24.9 & 0.3 \\
\hline $\mathrm{Ce}$ & 0.0929 & 0.9 & $\mathrm{Ni}$ & 1.12 & 0.0 \\
\hline $\mathrm{Co}$ & 0.00626 & 1.6 & $\mathrm{P}$ & 0.118 & 12 \\
\hline $\mathrm{Cr}$ & 0.0441 & 1.6 & $\mathrm{~Pb}$ & 0.0171 & 6.1 \\
\hline $\mathrm{Cu}$ & 0.0464 & 1.1 & $\mathrm{~S}$ & 0.663 & 4.9 \\
\hline $\mathrm{Fe}$ & 7.76 & 0.8 & $\mathrm{Si}$ & 0.254 & 19.4 \\
\hline $\mathrm{Gd}$ & 0.0550 & 0.7 & $\mathrm{Sr}$ & 0.0294 & 0.6 \\
\hline $\mathrm{Hg}$ & 2.06 & 24 & $\mathrm{Ti}$ & 0.0111 & 1.2 \\
\hline $\mathrm{K}$ & 0.0904 & 5.3 & $\mathrm{U}$ & 1.73 & 0.5 \\
\hline $\mathrm{La}$ & 0.0360 & 2.5 & $\mathrm{Zn}$ & 0.0287 & 3.3 \\
\hline $\mathrm{Li}$ & 0.0123 & 1.9 & $\mathrm{Zr}$ & 0.129 & 15 \\
\hline
\end{tabular}

Values in the \%RSD column are relative to the true calculated averages of the quantities in the tables, while the average values reported have been rounded off to a reasonable number of significant figures.

Table C - 16. Decant G (Supernate) Analysis

\begin{tabular}{|l|c|c|c||}
\hline & Unit & Result & \%RSD \\
\hline Supernate Density & $\mathrm{g} / \mathrm{mL}$ & 1.08 & 0.3 \\
\hline Fluoride & molar & $<0.0065$ & NA \\
\hline Formate & molar & $<0.0027$ & NA \\
\hline Chloride & molar & $<0.0035$ & NA \\
\hline Nitrite & molar & 0.392 & 6.4 \\
\hline Bromide & molar & $<0.0015$ & NA \\
\hline Nitrate & molar & 0.236 & 4.9 \\
\hline Phosphate & molar & $<0.0013$ & NA \\
\hline Sulfate & molar & 0.0219 & 0.8 \\
\hline Oxalate & molar & $<0.0014$ & NA \\
\hline $\mathrm{Al}$ & molar & 0.117 & 1.4 \\
\hline $\mathrm{B}$ & molar & 0.000812 & 0.6 \\
\hline $\mathrm{Ca}$ & molar & $3.59 \mathrm{E}-05$ & 3.6 \\
\hline $\mathrm{Cu}$ & molar & 0.000726 & 0.5 \\
\hline $\mathrm{La}$ & molar & 0.00266 & 7.2 \\
\hline $\mathrm{Mo}$ & molar & $7.52 \mathrm{E}-05$ & 1.5 \\
\hline $\mathrm{Na}$ & molar & 1.62 & 1.6 \\
\hline $\mathrm{P}$ & molar & 0.000740 & 1.7 \\
\hline $\mathrm{S}$ & molar & 0.0272 & 0.4 \\
\hline $\mathrm{Zr}$ & molar & $5.96 \mathrm{E}-06$ & 4.6 \\
\hline
\end{tabular}

Results are averages of four measurements. Anions are determined from IC, and elementals from ICPAES.

Values in the \%RSD column are relative to the true calculated averages of the quantities in the tables, while the average values reported have been rounded off to a reasonable number of significant figures. 
SRNL-STI-2010-00353

Revision 0

Table C - 17. Decant H (Supernate) Analysis.

\begin{tabular}{|c|c|c|c|}
\hline & Unit & Result & \%RSD \\
\hline Supernate Density & $\mathrm{g} / \mathrm{mL}$ & 1.06 & 0.3 \\
\hline Fluoride & molar & $<0.0067$ & NA \\
\hline Formate & molar & $<0.0028$ & NA \\
\hline Chloride & molar & $<0.0036$ & NA \\
\hline Nitrite & molar & 0.297 & 1.8 \\
\hline Bromide & molar & $<0.0016$ & NA \\
\hline Nitrate & molar & 0.144 & 1.7 \\
\hline Phosphate & molar & $<0.0013$ & NA \\
\hline Sulfate & molar & 0.0174 & 2 \\
\hline Oxalate & molar & $<0.0014$ & NA \\
\hline $\mathrm{Al}$ & molar & 0.0907 & 0.2 \\
\hline $\mathrm{B}$ & molar & 0.000686 & 0.4 \\
\hline $\mathrm{Ca}$ & molar & 7.00E-05 & 10 \\
\hline $\mathrm{Cr}$ & molar & 0.000574 & 0.4 \\
\hline $\mathrm{Fe}$ & molar & 1.31E-05 & 118 \\
\hline $\mathrm{K}$ & molar & 0.00189 & 2.8 \\
\hline Mo & molar & 5.62E-05 & 8.2 \\
\hline $\mathrm{Na}$ & molar & 1.28 & 0.3 \\
\hline $\mathrm{P}$ & molar & 0.000556 & 4.6 \\
\hline $\mathrm{S}$ & molar & 0.0211 & 0.4 \\
\hline
\end{tabular}

Results are averages of four measurements. Anions are determined from IC, and elementals from ICPAES.

Values in the \%RSD column are relative to the true calculated averages of the quantities in the tables, while the average values reported have been rounded off to a reasonable number of significant figures. 
SRNL-STI-2010-00353

Revision 0

Table C - 18. Decant I (Supernate) Analysis

\begin{tabular}{|l|c|c|c||}
\hline & Unit & Result & \%RSD \\
\hline Supernate Density & g/mL & 1.06 & NA \\
\hline Fluoride & molar & $<0.0065$ & NA \\
\hline Formate & molar & $<0.0027$ & NA \\
\hline Chloride & molar & $<0.0035$ & 2.6 \\
\hline Nitrite & molar & 0.237 & NA \\
\hline Bromide & molar & $<0.0015$ & 2.7 \\
\hline Nitrate & molar & 0.124 & NA \\
\hline Phosphate & molar & $<0.0013$ & 2.2 \\
\hline Sulfate & molar & 0.0149 & NA \\
\hline Oxalate & molar & $<0.0014$ & 1.1 \\
\hline Al & molar & 0.0759 & 8.5 \\
\hline $\mathrm{B}$ & molar & 0.000657 & 25 \\
\hline $\mathrm{Ca}$ & molar & 0.0000986 & NA \\
\hline $\mathrm{Fe}$ & molar & 0.0000230 & 5.2 \\
\hline $\mathrm{K}$ & molar & 0.00166 & 5.2 \\
\hline $\mathrm{Mo}$ & molar & 0.0000448 & 0.9 \\
\hline $\mathrm{Na}$ & molar & 1.08 & 2.9 \\
\hline $\mathrm{P}$ & molar & 0.000461 & 2.5 \\
\hline $\mathrm{S}$ & molar & 0.0178 & \\
\hline
\end{tabular}

Results are averages of four measurements. Anions are determined from IC, and elementals from ICPAES.

${ }^{\dagger}$ Reported result is for a single replicate; the other three replicates were reported as less than detectable. Values in the \%RSD column are relative to the true calculated averages of the quantities in the tables, while the average values reported have been rounded off to a reasonable number of significant figures. 
SRNL-STI-2010-00353

Revision 0

Table C - 19. Densities and Weight Percent Solids for Tank 51 SB6 Qualification SRAT Receipt Sample

\begin{tabular}{||l|c||}
\hline Property & $\begin{array}{c}\text { Result } \\
\text { (\%RSD) }\end{array}$ \\
\hline $\begin{array}{l}\text { Slurry Density } \\
\text { (g/mL) } \dagger\end{array}$ & $1.13(1.5)$ \\
\hline $\begin{array}{c}\text { Supernate Density } \\
\text { (g/mL) } \ddagger\end{array}$ & $1.06(0.6)$ \\
\hline $\begin{array}{c}\mathrm{Wt} \% \text { Total Solids } \\
\text { (Slurry Basis) }\end{array}$ & $15.1(0.7)$ \\
\hline $\begin{array}{c}\mathrm{Wt} \% \text { Calcined Solids } \\
\text { (Slurry Basis) }\end{array}$ & $11.9(0.8)$ \\
\hline $\begin{array}{c}\mathrm{Wt} \% \text { Dissolved Solids } \\
\text { (Supernate Basis) }\end{array}$ & $5.80(1.2)$ \\
\hline $\begin{array}{c}\mathrm{Wt} \% \text { Soluble Solids } \\
\text { (Slurry Basis) }\end{array}$ & $5.23(0.6)^{\mathrm{c}}$ \\
\hline $\begin{array}{c}\mathrm{Wt} \% \text { Insoluble Solids } \\
\text { (Slurry Basis) }\end{array}$ & $9.89(0.7)^{\mathrm{c}}$ \\
\hline
\end{tabular}

$\dagger$ Temperature at time of slurry density measurements was $6{ }^{\circ} \mathrm{C}$.

$\$$ Temperature at time of supernate density measurements was $7{ }^{\circ} \mathrm{C}$.

${ }^{a}$ Also known as Uncorrected Soluble Solids

${ }^{\mathrm{b}}$ Also known as Corrected Soluble Solids

c \%RSD here is more correctly defined as \% standard error for these calculated values

Values in the \%RSD column are relative to the true calculated averages of the quantities in the tables, while the average values reported have been rounded off to a reasonable number of significant figures. 
SRNL-STI-2010-00353

Revision 0

Table C - 20. Concentrations of Elements in Total Dried Solids and Calcined Solids for the Tank 51 SB6 Qualification SRAT Receipt Sample.

\begin{tabular}{|c|c|c|c|c|c|}
\hline Element & $\begin{array}{l}\text { Wt\% Total } \\
\text { Solids }\end{array}$ & $\begin{array}{c}\text { Wt\% Calcine } \\
\text { Solids }\end{array}$ & \%RSD & Instrument & $\begin{array}{c}\text { Prep } \\
\text { Method }\end{array}$ \\
\hline $\mathrm{Ag}$ & 0.0138 & 0.0175 & 0.9 & ICP-MS & $\mathrm{AR}$ \\
\hline $\mathrm{Al}$ & 11.0 & 13.9 & 0.5 & ICP-AES & $\mathrm{PF}$ \\
\hline As & $<0.0010$ & $<0.0013$ & - & $\mathrm{AA}$ & AR \\
\hline $\mathrm{B}$ & $<0.0068$ & $<0.0087$ & - & ICP-AES & $\mathrm{AR}$ \\
\hline $\mathrm{Ba}$ & 0.0917 & 0.117 & 1.3 & ICP-AES & $\mathrm{AR} / \mathrm{PF}$ \\
\hline $\mathrm{Be}$ & $<0.00074$ & $<0.00094$ & - & ICP-AES & $\mathrm{AR}$ \\
\hline $\mathrm{Ca}$ & 0.527 & 0.670 & 0.9 & ICP-AES & $\mathrm{AR}$ \\
\hline $\mathrm{Cd}$ & 0.00799 & 0.0102 & 4.5 & ICP-AES & $\mathrm{AR} / \mathrm{PF}$ \\
\hline $\mathrm{Ce}$ & 0.139 & 0.177 & 0.7 & ICP-MS & AR \\
\hline $\mathrm{Co}$ & 0.00869 & 0.0110 & 1.8 & ICP-AES & $\mathrm{AR}$ \\
\hline $\mathrm{Cr}$ & 0.0448 & 0.0570 & 3.2 & ICP-AES & $\mathrm{AR} / \mathrm{PF}$ \\
\hline $\mathrm{Cu}$ & 0.0711 & 0.0903 & 2.3 & ICP-AES & $\mathrm{AR} / \mathrm{PF}$ \\
\hline $\mathrm{Fe}$ & 11.8 & 14.9 & 1.4 & ICP-AES & $\mathrm{AR} / \mathrm{PF}$ \\
\hline $\mathrm{Gd}$ & 0.0823 & 0.105 & 3.2 & ICP-MS & $\mathrm{AR}$ \\
\hline $\mathrm{Hg}$ & 3.12 & - & 6.7 & CVAA & AR \\
\hline $\mathrm{K}$ & 0.0595 & 0.0756 & 5.4 & ICP-AES & $\mathrm{AR}$ \\
\hline $\mathrm{La}$ & 0.0713 & 0.0907 & 1.2 & ICP-MS & $\overline{A R}$ \\
\hline $\mathrm{Li}$ & 0.0172 & 0.0218 & 2.0 & ICP-AES & $\mathrm{AR}$ \\
\hline $\mathrm{Mg}$ & 0.214 & 0.272 & 1.5 & ICP-AES & $\mathrm{AR} / \mathrm{PF}$ \\
\hline $\mathrm{Mn}$ & 4.15 & 5.28 & 0.9 & ICP-AES & $\mathrm{AR} / \mathrm{PF}$ \\
\hline Mo & 0.00514 & 0.00653 & 5.6 & ICP-AES & $\mathrm{AR}$ \\
\hline $\mathrm{Na}$ & 15.4 & 19.6 & 0.9 & ICP-AES & $\mathrm{AR}$ \\
\hline $\mathrm{Nd}$ & 0.258 & 0.328 & 0.3 & ICP-MS & AR \\
\hline $\mathrm{Ni}$ & 1.69 & 2.15 & 1.2 & ICP-AES & $\mathrm{AR} / \mathrm{PF}$ \\
\hline $\mathrm{P}$ & 0.143 & 0.181 & 7.2 & ICP-AES & PF \\
\hline $\mathrm{Pb}$ & 0.0158 & 0.0201 & 4.2 & ICP-MS & $\mathrm{AR}$ \\
\hline $\mathrm{S}$ & 0.375 & 0.477 & 4.7 & ICP-AES & AR \\
\hline $\mathrm{Se}$ & $<0.0021$ & $<0.0026$ & - & $\mathrm{AA}$ & AR \\
\hline $\mathrm{Sb}$ & $<0.014$ & $<0.018$ & - & ICP-AES & AR \\
\hline $\mathrm{Si}$ & 0.711 & 0.904 & 2.8 & ICP-AES & $\mathrm{PF}$ \\
\hline $\mathrm{Sn}$ & $<0.0081$ & $<0.010$ & - & ICP-AES & $\mathrm{AR}$ \\
\hline $\mathrm{Sr}$ & 0.0431 & 0.0548 & 1.8 & ICP-AES & $\mathrm{AR} / \mathrm{PF}$ \\
\hline $\mathrm{Ti}$ & 0.0164 & 0.0208 & 4.6 & ICP-AES & $\mathrm{AR} / \mathrm{PF}$ \\
\hline $\mathrm{Th}$ & 2.98 & 3.78 & 1.6 & ICP-MS & $\mathrm{AR}$ \\
\hline $\mathrm{U}$ & 2.33 & 2.97 & 1.1 & ICP-MS & $\mathrm{AR}$ \\
\hline $\mathrm{V}$ & $<0.0046$ & $<0.0058$ & - & ICP-AES & $\mathrm{AR}$ \\
\hline $\mathrm{Zn}$ & 0.0413 & 0.0525 & 8.0 & ICP-AES & $\mathrm{AR} / \mathrm{PF}$ \\
\hline $\mathrm{Zr}^{\dagger}$ & 0.156 & 0.198 & 2.1 & ICP-AES & $\mathrm{AR}$ \\
\hline
\end{tabular}

Results are averages of dissolution and analysis of four or eight aliquots of the SB6 slurry.

${ }^{\dagger}$ Reported result is the average of three replicates.

ICP-MS $\equiv$ inductively coupled plasma - mass spectrometry, ICP-AES $\equiv$ inductively coupled plasma atomic emission spectroscopy, CVAA $\equiv$ cold vapor atomic absorption spectroscopy, $\mathrm{AA} \equiv$ Atomic Absorption, $\mathrm{AR} \equiv$ aqua regia digestion, $\mathrm{PF} \equiv$ peroxide fusion digestion.

Values in the \%RSD column are relative to the true calculated averages of the quantities in the tables, while the average values reported have been rounded off to a reasonable number of significant figures. 
Table C - 21. Concentrations of Noble Metals and Silver in Total Dried Solids for the SRAT Receipt Tank 51 SB6 Qualification Sample.

\begin{tabular}{||l|c|c||}
\hline \hline Element & Wt\% Total Solids & \%RSD \\
\hline $\mathrm{Ru}$ & 0.0924 & 0.2 \\
\hline $\mathrm{Rh}$ & 0.0187 & 3.4 \\
\hline $\mathrm{Pd}$ & 0.00304 & 0.5 \\
\hline $\mathrm{Ag}$ & 0.0138 & 0.9 \\
\hline
\end{tabular}

Results are Averages of Aqua Regia Digestions and ICP-MS Analyses of Four SB6 Slurry Aliquots Values in the \%RSD column are relative to the true calculated averages of the quantities in the tables, while the average values reported have been rounded off to a reasonable number of significant figures.

Table C - 22. Concentrations of Anions and Cations on a Slurry Basis for the SRAT Receipt Tank 51 SB6 Qualification Sample

\begin{tabular}{||l|c|c||}
\hline Anion & mg/kg slurry & \%RSD \\
\hline $\mathrm{Br}^{-}$ & $<100$ & - \\
\hline $\mathrm{Cl}^{-}$ & $<100$ & - \\
\hline $\mathrm{F}^{-}$ & $<100$ & - \\
\hline $\mathrm{HCO}_{2}{ }^{-}$ & 100 & 7.8 \\
\hline $\mathrm{NO}_{3}{ }^{-}$ & 6,840 & 1.2 \\
\hline $\mathrm{NO}_{2}{ }^{-}$ & 10,000 & 0.7 \\
\hline $\mathrm{C}_{2} \mathrm{O}_{4}{ }^{2-}$ & $<100$ & - \\
\hline $\mathrm{PO}_{4}{ }^{3-}$ & $<100$ & - \\
\hline $\mathrm{SO}_{4}{ }^{2-}$ & 1200 & 0.8 \\
\hline \hline
\end{tabular}

Results are averages of four SB6 slurry aliquots.

Values in the \%RSD column are relative to the true calculated averages of the quantities in the tables, while the average values reported have been rounded off to a reasonable number of significant figures.

Table C - 23. Slurry Concentrations of Total Base, Free Hydroxide, and Other Bases Excluding Carbonate for the SRAT Receipt Tank 51 SB6 Qualification Sample

\begin{tabular}{||c|c|c||}
\hline Species & Mol/L Slurry & \%RSD \\
\hline Total Base & 0.58 & 4.8 \\
\hline Free $\mathrm{OH}^{-}$ & 0.40 & 1.8 \\
\hline $\begin{array}{c}\text { Other Base Excluding } \\
\mathrm{CO}_{3}^{2-}\end{array}$ & 0.12 & 8.9 \\
\hline
\end{tabular}

Results are averages of four SB6 slurry aliquots.

Values in the \%RSD column are relative to the true calculated averages of the quantities in the tables, while the average values reported have been rounded off to a reasonable number of significant figures.

Table C - 24. Slurry and Supernate Concentrations of TIC/TOC for the SRAT Receipt Tank 51 SB6 Qualification Sample. •

\begin{tabular}{|c|c|c|c|c||}
\hline Species & mg/kg slurry & \%RSD & mg/L supernate & \%RSD \\
\hline Total Inorganic Carbon & 913 & 16 & 910 & 5.5 \\
\hline Total Organic Carbon & 483 & 71 & $<70$ & - \\
\hline Total Carbon & 1400 & 19 & 910 & 5.5 \\
\hline
\end{tabular}

Results are averages of four SB6 slurry aliquots and three SB6 supernate aliquots.

Values in the \%RSD column are relative to the true calculated averages of the quantities in the tables, while the average values reported have been rounded off to a reasonable number of significant figures. 
Table C - 25. Weight Percent Solids, Density, and pH of the SB6 Qualification SRAT Product

\begin{tabular}{||c|c|c||}
\hline Property & Result & \%RSD \\
\hline Weight \% Total Solids (slurry basis) & 25.9 & 0.2 \\
\hline Weight\% Dissolved Solids (supernate basis) & 9.35 & 0.3 \\
\hline Weight \% Insoluble Solids (slurry basis) & 18.3 & NA \\
\hline Weight\% Soluble Solids (slurry basis) & 7.6 & NA \\
\hline Weight \% Calcined Solids (slurry basis) & 17.7 & 0.4 \\
\hline Slurry Density (g/mL) & 1.23 & 0.8 \\
\hline Supernate Density (g/mL) & 1.08 & 3 \\
\hline $\mathrm{pH}$ & 10 & NA \\
\hline
\end{tabular}

Values in the \%RSD column are relative to the true calculated averages of the quantities in the tables, while the average values reported have been rounded off to a reasonable number of significant figures.

Table C - 26. Concentrations of Anions, Amonium, and Carbon on a Slurry Basis for the SB6 Qualification SRAT Product

\begin{tabular}{||l|c|c||}
\hline \hline Analyte & mg/kg slurry & \%RSD \\
\hline Fluoride & $<1,000$ & NA \\
\hline Formate & 43,600 & $1 \%$ \\
\hline Chloride & $<1,000$ & NA \\
\hline Nitrite & $<1,000$ & NA \\
\hline Nitrate & 26,200 & $1 \%$ \\
\hline Phosphate & $<100$ & NA \\
\hline Sulfate & 2,370 & $6 \%$ \\
\hline Oxalate & $<100$ & NA \\
\hline Ammonium & $<200$ & NA \\
\hline Total Carbon & $\dagger$ & NA \\
\hline Total Inorganic Carbon & 17,400 & 2 \\
\hline Total Organic Carbon & 1,800 & 0.8 \\
\hline \hline
\end{tabular}

Results are averages of four SB6 slurry aliquots.

${ }^{\dagger}$ Total Carbon $=$ Total Inorganic Carbon + Total Organic Carbon

Values in the \%RSD column are relative to the true calculated averages of the quantities in the tables, while the average values reported have been rounded off to a reasonable number of significant figures.

Table C - 27. Physical Properties of As-Made SB6 SME Product (Prior to Dilution to 45 wt \% Total Solids)

\begin{tabular}{|c|c|c|c||}
\hline Property & Result & \% RSD & \# of Replicates \\
\hline \hline Wt \% Total Solids & 52.5 & $0.4 \%$ & 4 replicates \\
\hline Wt \% Calcined Solids & 46.9 & NA & 1 replicate \\
\hline $\begin{array}{c}\text { Calcine Factor (mass oxides/mass total } \\
\text { solids) }\end{array}$ & 0.89 & NA & NA \\
\hline Wt \% Dissolved Solids & \multirow{2}{*}{ NA - SME product was too thick and sticky for } \\
adequate measurement.
\end{tabular}

Values in the \%RSD column are relative to the true calculated averages of the quantities in the tables, while the average values reported have been rounded off to a reasonable number of significant figures. 
SRNL-STI-2010-00353

Revision 0

Table C - 28. SB6 SME Product (at 45 wt \% Total Solids) Density, Anion, and Cation Concentrations

\begin{tabular}{||c|c|c|c||}
\hline Measurement & $\begin{array}{c}\text { Result } \\
\text { (mg/kg slurry) }\end{array}$ & \% RSD & $\begin{array}{c}\text { \# of } \\
\text { Replicates }\end{array}$ \\
\hline \hline Density, $\mathrm{T}=21^{\circ} \mathrm{C}$ & 1.42 & NA & 1 replicate $^{\dagger}$ \\
\hline Fluoride & $<50$ & NA & - \\
\hline Formate & 26,300 & 2 & 4 replicates \\
\hline Chloride & $<50$ & NA & - \\
\hline Nitrite & 613 & 2 & - \\
\hline Bromide & $<50$ & NA & - \\
\hline Nitrate & 15,500 & 1 & 4 replicates \\
\hline Phosphate & $<300$ & NA & - \\
\hline Sulfate & 1,450 & 2 & - \\
\hline Oxalate & 147 & 8 & - \\
\hline Ammonium & $<2,500$ & NA & - \\
\hline
\end{tabular}

${ }^{\dagger}$ Because of the stickiness of the sample and difficulty in removing it from the density measurement container, the density measurement was not repeated. It should be noted that the measured density is similar to what one would expect for a $\sim 50 \mathrm{wt} \%$ total solids SME product.

Values in the \%RSD column are relative to the true calculated averages of the quantities in the tables, while the average values reported have been rounded off to a reasonable number of significant figures.

Table C - 29. SB6 SME Product (at 45 wt \% Total Solids) Carbon Analysis

\begin{tabular}{|c|c|c|c||}
\hline Analyte & $\begin{array}{c}\text { Average } \\
\text { (mg/kg slurry) }\end{array}$ & \% RSD & \# of Replicates \\
\hline \hline Total Inorganic Carbon & 1,800 & 7 & 3 \\
\hline Total Organic Carbon & 10,200 & 1 & 4 \\
\hline Total Carbon & $12,000^{\dagger}$ & NA & NA \\
\hline
\end{tabular}

+ Total Carbon $=$ Total Inorganic Carbon + Total Organic Carbon

Values in the \%RSD column are relative to the true calculated averages of the quantities in the tables, while the average values reported have been rounded off to a reasonable number of significant figures. 
SRNL-STI-2010-00353

Revision 0

Appendix D. Supplemental PCT Data 
SRNL-STI-2010-00353

Revision 0

Table D - 1. PCT Elemental Releases for ARM, EA and the SB6 Qualification Glass

\begin{tabular}{||c|c|c|c|c|c|c|c||}
\hline \multirow{2}{*}{ Glass ID } & \multicolumn{7}{|c|}{ Elemental Release - Dilution Factor Corrected (ppm) } \\
\cline { 2 - 9 } & $\mathrm{Li}$ & $\mathrm{B}$ & $\mathrm{Na}$ & $\mathrm{Si}$ & $\mathrm{Al}$ & $\mathrm{Fe}$ & $\mathrm{U}$ \\
\hline \hline ARM-1-P83 & 13.076 & 15.906 & 35.385 & 58.301 & 4.853 & $<0.071$ & $<2.996$ \\
\hline ARM-2-P85 & 13.506 & 16.975 & 37.048 & 59.950 & 4.883 & $<0.071$ & $<2.994$ \\
\hline ARM-3-P86 & 12.806 & 15.637 & 34.711 & 57.290 & 4.852 & $<0.071$ & $<2.996$ \\
\hline EA-1-P72 & 196.785 & 602.821 & 1677.682 & 907.297 & $<3.842$ & $<0.429$ & $<18.166$ \\
\hline EA-2-P74 & 192.660 & 594.529 & 1654.876 & 892.816 & $<3.841$ & $<0.429$ & $<18.163$ \\
\hline EA-3-P76 & 199.053 & 637.623 & 1771.857 & 940.085 & $<3.842$ & $<0.429$ & $<18.168$ \\
\hline SB-6 GLS-1-P77 & 19.583 & 9.977 & 91.343 & 118.982 & 20.392 & 6.404 & 4.382 \\
\hline SB-6 GLS-2-P80 & 20.041 & 10.273 & 93.301 & 119.910 & 20.311 & 5.254 & 4.379 \\
\hline SB-6 GLS-3-P81 & 19.403 & 9.870 & 90.279 & 115.206 & 19.942 & 5.491 & 4.177 \\
\hline SB-6 GLS-4-P82 & 20.311 & 10.442 & 94.312 & 120.584 & 20.445 & 5.288 & 4.513 \\
\hline \hline
\end{tabular}


SRNL-STI-2010-00353

Revision 0

Appendix E. Settling Data 
SRNL-STI-2010-00353

Revision 0

\begin{tabular}{|c|c|c|c|c|c|c|c|c|c|}
\hline Decant A & & & & & Decant E & & & & \\
\hline Date & Time & Level $(\mathrm{mL})$ & Setling time $(d)$ & Relative level & Date & Time & Level $(\mathrm{mL})$ & Setling time $(\mathrm{d})$ & Relative level \\
\hline $10 / 13 / 2009$ & & 2700 & 0.0 & 1 & $12 / 7 / 2009$ & $16: 50$ & 3300 & 0.0 & 1 \\
\hline $10 / 15 / 2009$ & & 2600 & 2.0 & 0.962962963 & $12 / 8 / 2009$ & $7: 30$ & 3225 & 0.6 & 0.977272727 \\
\hline $10 / 16 / 2009$ & & 2560 & 3.0 & 0.948148148 & $12 / 8 / 2009$ & $12: 25$ & 3000 & 0.8 & 0.909090909 \\
\hline $10 / 17 / 2009$ & & 2500 & 4.0 & 0.925925926 & $12 / 8 / 2009$ & $17: 00$ & 2930 & 1.0 & 0.887878788 \\
\hline $10 / 18 / 2009$ & & 2440 & 5.0 & 0.903703704 & $12 / 9 / 2009$ & $7: 10$ & 2800 & 1.6 & 0.848484848 \\
\hline $10 / 19 / 2009$ & & 2400 & 6.0 & 0.888888889 & 10-Dec & $7: 05$ & 2610 & 2.6 & 0.790909091 \\
\hline $10 / 20 / 2009$ & & 2390 & 7.0 & 0.885185185 & 11-Dec & $6: 50$ & 2400 & 3.6 & 0.727272727 \\
\hline $10 / 21 / 2009$ & & 2380 & 8.0 & 0.881481481 & & & & & \\
\hline $10 / 22 / 2009$ & & 2370 & 9.0 & 0.877777778 & Decant F & & & & \\
\hline $10 / 23 / 2009$ & & 2290 & 10.0 & 0.848148148 & Date & Time & Level $(\mathrm{mL})$ & Setling time (d) & Relative level \\
\hline $10 / 26 / 2009$ & & 2190 & 13.0 & 0.811111111 & $12 / 11 / 2009$ & $13: 30$ & 3300 & 0.0 & 1 \\
\hline $10 / 27 / 2009$ & & 2175 & 14.0 & 0.805555556 & $12 / 14 / 2009$ & $8: 00$ & 2550 & 2.8 & 0.772727273 \\
\hline $10 / 28 / 2009$ & & 2120 & 15.0 & 0.785185185 & $12 / 15 / 2009$ & $7: 00$ & 2350 & 3.7 & 0.712121212 \\
\hline $10 / 29 / 2009$ & & 2075 & 16.0 & 0.768518519 & & & & & \\
\hline $10 / 30 / 2009$ & & 2050 & 17.0 & 0.759259259 & Decant G & & & & \\
\hline $10 / 31 / 2009$ & & 2030 & 18.0 & 0.751851852 & Date & Time & Level $(\mathrm{mL})$ & Setling time (d) & Relative level \\
\hline $11 / 1 / 2009$ & & 2000 & 19.0 & 0.740740741 & $12 / 15 / 2009$ & $13: 55$ & 3250 & 0.0 & 1 \\
\hline \multirow[t]{2}{*}{$11 / 2 / 2009$} & & 1990 & 20.0 & 0.737037037 & $12 / 16 / 2009$ & $10: 30$ & 2950 & 0.9 & 0.907692308 \\
\hline & & & & & $12 / 16 / 2009$ & $16: 00$ & 2850 & 1.1 & 0.876923077 \\
\hline Decant B & & & & & $12 / 17 / 2009$ & $7: 00$ & 2625 & 1.7 & 0.807692308 \\
\hline Date & Time & Level $(\mathrm{mL})$ & Setling time (d) & Relative level & $12 / 21 / 2009$ & $7: 00$ & 2000 & 5.7 & 0.615384615 \\
\hline $11 / 5 / 2009$ & $15: 00$ & 3450 & 0.0 & 1 & & & & & \\
\hline $11 / 6 / 2009$ & $8: 00$ & 3300 & 0.7 & 0.956521739 & & & & & \\
\hline $11 / 7 / 2009$ & $14: 00$ & 3100 & 2.0 & 0.898550725 & Decant $\mathrm{H}$ & & & & \\
\hline $11 / 9 / 2009$ & $6: 40$ & 2925 & 3.7 & 0.847826087 & Date & Time & Level $(\mathrm{mL})$ & Setling time (d) & Relative level \\
\hline $11 / 10 / 2009$ & $7: 00$ & 2795 & 4.7 & 0.810144928 & $12 / 21 / 2009$ & $13: 55$ & 3250 & 0.0 & 1 \\
\hline $11 / 11 / 2009$ & $7: 00$ & 2760 & 5.7 & 0.8 & $12 / 22 / 2009$ & $8: 00$ & 2850 & 0.8 & 0.876923077 \\
\hline $11 / 12 / 2009$ & $7: 00$ & 2610 & 6.7 & 0.756521739 & $12 / 23 / 2009$ & $6: 50$ & 2700 & 1.7 & 0.830769231 \\
\hline $11 / 13 / 2009$ & $7: 00$ & 2500 & 7.7 & 0.724637681 & $12 / 23 / 2009$ & $16: 45$ & 2550 & 2.1 & 0.784615385 \\
\hline $11 / 14 / 2009$ & $13: 00$ & 2400 & 8.9 & 0.695652174 & $12 / 26 / 2009$ & $14: 00$ & 2010 & 5.0 & 0.618461538 \\
\hline $11 / 16 / 2009$ & $5: 20$ & 2300 & 10.6 & 0.666666667 & $12 / 28 / 2009$ & $7: 00$ & 1975 & 6.7 & 0.607692308 \\
\hline \multirow{2}{*}{\multicolumn{10}{|c|}{ Decant C }} \\
\hline & & & & & & & & & \\
\hline Date & Time & Level $(\mathrm{mL})$ & Setling time (d) & Relative level & Decant I & & & & \\
\hline $11 / 18 / 2009$ & $15: 45$ & 3450 & 0.0 & 1 & Date & Time & Level $(\mathrm{mL})$ & Setling time $(\mathrm{d})$ & Relative level \\
\hline $11 / 19 / 2009$ & $16: 00$ & 3200 & 1.0 & 0.927536232 & \begin{tabular}{|c|}
$12 / 28 / 2009$ \\
\end{tabular} & $14: 45$ & 3250 & 0.0 & 1 \\
\hline $11 / 20 / 2009$ & $13: 00$ & 2900 & 1.9 & 0.84057971 & $12 / 29 / 2009$ & $8: 00$ & 2950 & 0.7 & 0.907692308 \\
\hline $11 / 21 / 2009$ & $12: 00$ & 2810 & 2.8 & 0.814492754 & $12 / 29 / 2009$ & $16: 00$ & 2800 & 1.1 & 0.861538462 \\
\hline $11 / 23 / 2009$ & $8: 45$ & 2620 & 4.7 & 0.75942029 & $12 / 30 / 2009$ & $6: 30$ & 2600 & 1.7 & 0.8 \\
\hline $11 / 24 / 2009$ & $6: 50$ & 2550 & 5.6 & 0.739130435 & $12 / 30 / 2009$ & $16: 30$ & 2480 & 2.1 & 0.763076923 \\
\hline $11 / 25 / 2009$ & $9: 50$ & 2400 & 6.8 & 0.695652174 & $12 / 31 / 2009$ & $11: 00$ & 2250 & 2.8 & 0.692307692 \\
\hline $11 / 27 / 2009$ & $13: 00$ & 2230 & 8.9 & 0.646376812 & $1 / 2 / 2010$ & $13: 00$ & 2000 & 4.9 & 0.615384615 \\
\hline $11 / 28 / 2009$ & $13: 00$ & 2200 & 9.9 & 0.637681159 & $1 / 4 / 2010$ & $8: 10$ & 1975 & 6.7 & 0.607692308 \\
\hline \multirow[t]{2}{*}{$11 / 30 / 2009$} & $6: 00$ & 2125 & 11.6 & 0.615942029 & $1 / 5 / 2010$ & $8: 30$ & 1900 & 7.7 & 0.584615385 \\
\hline & & & & & $1 / 6 / 2010$ & $5: 30$ & 1900 & 8.6 & 0.584615385 \\
\hline Decant D & & & & & $1 / 7 / 2010$ & $9: 30$ & 1900 & 9.8 & 0.584615385 \\
\hline Date & Time & Level $(\mathrm{mL})$ & Setling time $(d)$ & Relative level & & & & & \\
\hline $12 / 1 / 2009$ & $11: 50$ & 3200 & 0.0 & \begin{tabular}{|r|}
1 \\
\end{tabular} & & & & & \\
\hline $12 / 2 / 2009$ & $7: 05$ & 3000 & 0.8 & 0.9375 & & & & & \\
\hline $12 / 3 / 2009$ & $14: 50$ & 2820 & 2.1 & 0.88125 & & & & & \\
\hline $12 / 4 / 2009$ & $12: 50$ & 2600 & 3.0 & 0.753623188 & & & & & \\
\hline $12 / 7 / 2009$ & $12: 15$ & 2250 & 6.0 & 0.652173913 & & & & & \\
\hline
\end{tabular}


SRNL-STI-2010-00353

Revision 0

\section{Appendix F. Rheology Flow Curves}




\section{SRAT Receipt}
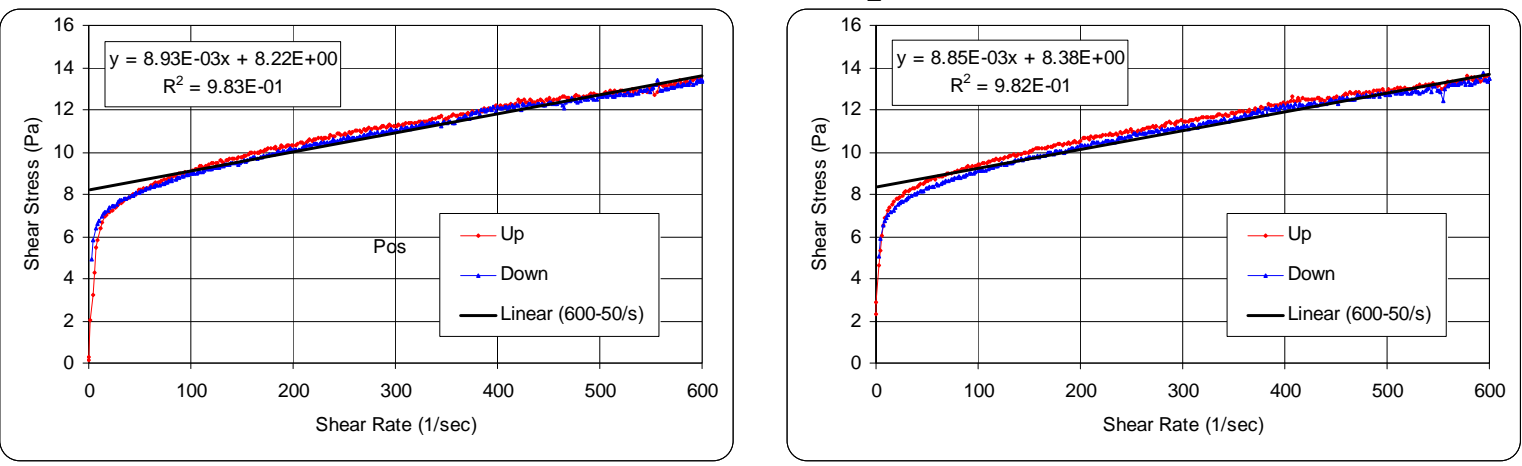

SRAT Material Following Caustic Boiling/Concentration
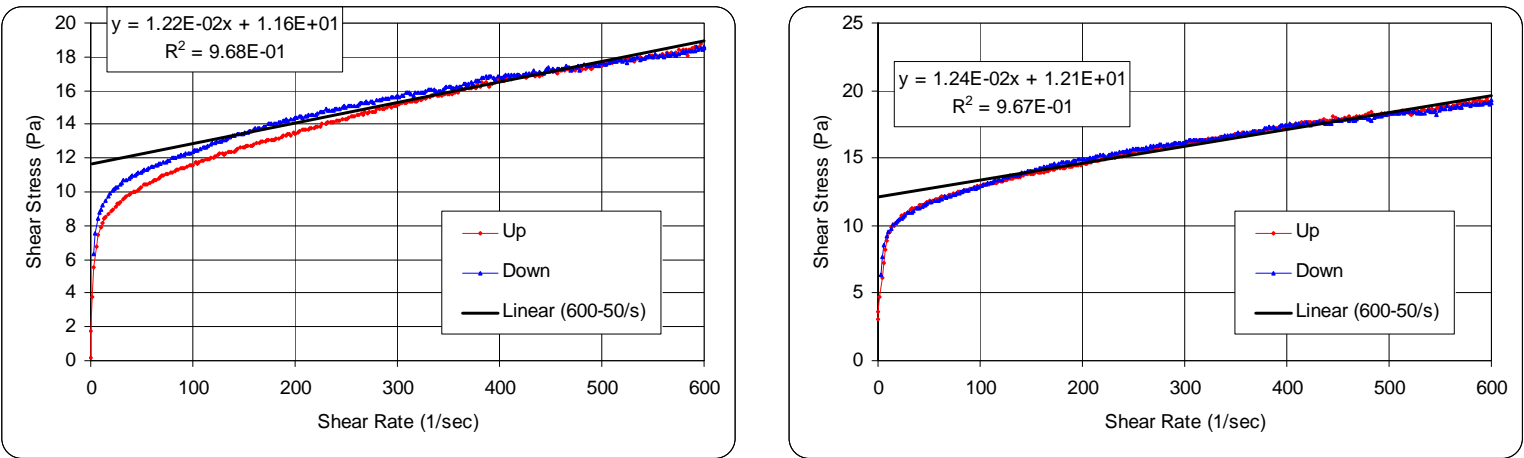

SRAT Product
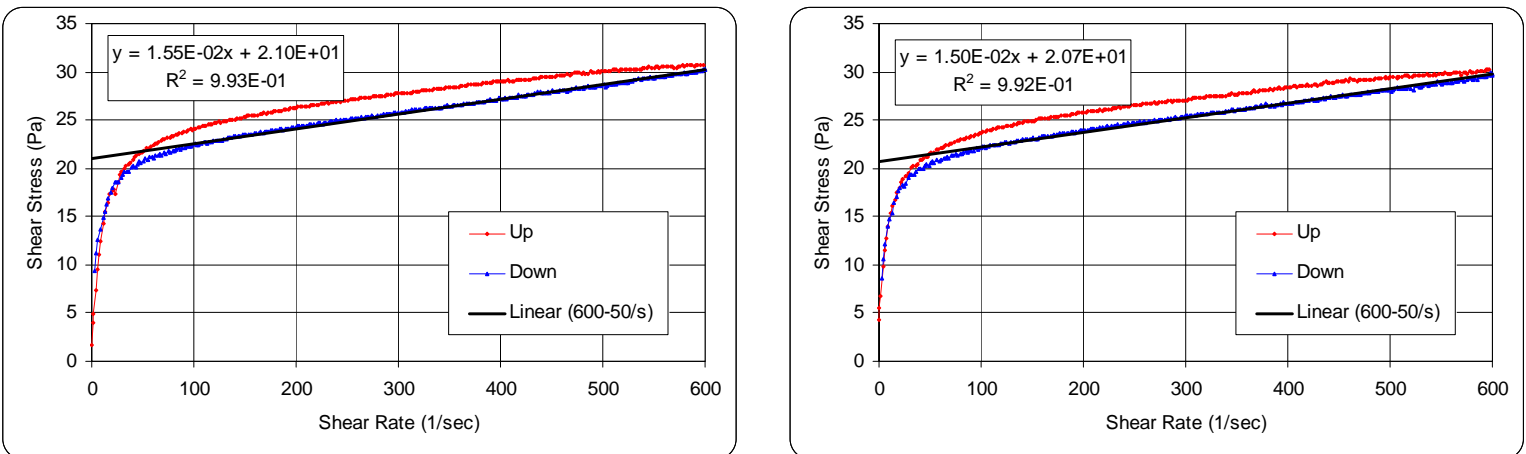


\section{Distribution:}
A. B. Barnes, 999-W
D. A. Crowley, 773-43A
S. D. Fink, 773-A
B. J. Giddings, 786-5A
C. C. Herman, 999-W
S. L. Marra, 773-A
F. M. Pennebaker, 773-42A
C. J. Bannochie, 773-42A
J. M. Gillam, 766-H
B. A. Hamm, 766-H
J. F. Iaukea, 704-30S
A. V. Staub, 704-27S
J. E. Occhipinti, 704-S
D. K. Peeler, 999-W
J. W. Ray, 704-S
H. B. Shah, 766-H
D. C. Sherburne, 704-S
M. E. Stone, 999-W
M. A. Broome, 704-29S
R. N. Hinds, 704-S
J. P. Vaughan, 773-41A
J. M. Bricker, 704-27S
T. L. Fellinger, 704-26S
E. W. Holtzscheiter, 704-15S
M. T. Keefer, 766-H 